\title{
SALMONELLA, ENTERIC FEVERS, AND SALMONELLOSIS
}

\author{
Rumina Hasan \\ The Aga Khan University \\ London School of Hygiene and Tropical Medicine
}

Karachi, Pakistan

Annika C. Nordin

Swedish University of Agricultural Sciences

Uppsala, Sweden

Sadia Shakoor

The Aga Khan University

Karachi, Pakistan

Ishi Keenum

Virginia Tech

Blacksburg, United States

\section{Björn Vinneras}

Swedish University of Agricultural Sciences

Uppsala, Sweden 


\section{Copyright:}

\section{cc) (i) (2) \\ BY SA}

This publication is available in Open Access under the Attribution-ShareAlike 3.0 IGO (CC-BY-SA 3.0 IGO) license (http://creativecommons.org/licenses/by-sa/3.0/igo). By using the content of this publication, the users accept to be bound by the terms of use of the UNESCO Open Access Repository (http://www.unesco.org/openaccess/terms-use-ccbysa-en).

\section{Disclaimer:}

The designations employed and the presentation of material throughout this publication do not imply the expression of any opinion whatsoever on the part of UNESCO concerning the legal status of any country, territory, city or area or of its authorities, or concerning the delimitation of its frontiers or boundaries. The ideas and opinions expressed in this publication are those of the authors; they are not necessarily those of UNESCO and do not commit the Organization.

\section{Citation:}

Hasan, R., Nordin, A.C., Shakoor, S., Keenum, I. and Vinneras, B. 2019. Salmonella, Enteric Fevers, and Salmonellosis. In: J.B. Rose and B. Jiménez-Cisneros, (eds) Global Water Pathogen Project. http://www.waterpathogens.org ( A. Pruden, N. Ashbolt and J. Miller (eds) Part 3 Baceteria) http://www.waterpathogens.org/book/salmonella-enteric-fevers-salmonellosis. Michigan State University, E. Lansing, MI, UNESCO.

https://doi.org/10.14321/waterpathogens.27

Acknowledgements: K.R.L. Young, Project Design editor; Website Design: Agroknow (http://www.agroknow.com)

Last published: September 12, 2019 


\section{Summary}

Salmonella species are widespread across the globe and associated with both human and animal hosts. The genus Salmonella includes the species $S$. enterica. S. enterica is further subdivided into subspecies amongst which Salmonella enterica subspecies enterica includes many of pathogens important for human disease. While newer molecular methods provide good species and subspecies level discrimination for Salmonella, many laboratories still rely on antigenic structure based on the initial KauffmanWhite-Le Minor (KWL) scheme which remains valid.

In humans, Salmonella infections are most prevalent in lowto-middle income countries and are divided into infections caused by typhoidal and non-typhoidal salmonellae. Typhoidal salmonellae; Salmonella enterica serovars Typhi, Paratyphi A, B and C are restricted to human hosts and associated with invasive disease (enteric fever). Nontyphoidal salmonellae (NTS), which may be of zoonotic origin, are primarily associated with non-invasive disease. In both Africa and Asia, burden of salmonella infections is highest in children. Salmonella strains show geographical differences with different strain types being prevalent in different regions.

Clinically, enteric fever typically presents with fever and gastrointestinal symptoms. Complications include intestinal bleeding/perforation (in older children and adults) and paralytic ileus in younger children. Additional complications include cardiopulmonary disorders, bronchopneumonia, thrombocytopenia/anaemia (particularly amongst children in Africa), as well as sepsis. NTS infections are typically associated with gastroenteritis, although in immunocompromised (e.g., in patients with HIV), NTS may also result in invasive disease. It is suggested that genomic differences may be linked to noninvasive versus invasive behaviour of Salmonella strains.

The main reservoir for salmonellae is the gastrointestinal tract of vertebrates, with bacteria being shed in stool. Spread is through the fecal-oral route. Environmental factors; including contaminated food, water and poor hand hygiene, contribute to dissemination. Prevention of
Salmonella infections centers on safe water, sanitation and hygiene, food safety, and vaccination where available. Commercial vaccines are available for human use against the enteric or typhoid fever causing $S$. Typhi, and newer conjugate vaccines may have longer lasting immunity than capsular polysaccharide vaccine precursors.

Treatment technologies for reduction of Salmonella in wastewater fractions can be divided into three main types: chemical, biological and thermal. When comparing the inactivation of Salmonella spp. with Escherichia coli, the latter is somewhat more resistant to most treatments and can therefore be used as a proper indicator for salmonella during treatments. Salmonella has several geneticallydriven responses to stress related to the inactivation treatments, which increase survival during extreme conditions. In this chapter the inactivation time for salmonella in relation to $\mathrm{pH}$, ammonia concentration and temperature is presented. For $\mathrm{pH}$, generated inactivation chemical substances aid in the inactivation: at higher $\mathrm{pH}$ uncharged ammonia is the most active molecule enhancing inactivation while at low $\mathrm{pH}$ carbonate and organic acids both increase the efficiency of inactivation. For heat inactivation, increased dry matter content increases the time of survival. Biological treatments affect the survival, while also decreasing the number of viable Salmonella over time. However, the effect of the biological treatment is difficult to monitor and quantify and therefore extended treatment durations are recommended for biological treatment if the treatment is not combined with chemical or thermal treatment.

\subsection{Epidemiology of the Disease and Pathogen(s)}

\subsection{Global Burden of Disease}

\subsubsection{Global distribution}

Salmonella infections with both typhoidal as well as non-typhoidal salmonella are prevalent across the globe. These infections are particularly associated with low-tomiddle income countries in Africa (Table 1) and Asia (Table $2)$.

Table 1. Africa: Salmonella enterica serovar Typhi and invasive Non Typhoidal Salmonella (NTS) Burden

\begin{tabular}{|c|c|c|c|c|c|c|c|c|}
\hline Region & Years & \multicolumn{6}{|c|}{ Adjusted Incidence/ 100,000 PYO $(95 \% \mathrm{CI})^{\mathrm{a}}$} & \multirow[t]{2}{*}{ Reference } \\
\hline Age Groups & & 0 to 1 yr & 2 to $4 y r s$ & 5 to 14 yrs & $<15$ yrs & $>15$ yrs & Overall & \\
\hline \multicolumn{9}{|c|}{ S. Typhi } \\
\hline $\begin{array}{l}\text { Burkina Faso } \\
\text { (Nioko 11) }\end{array}$ & $\begin{array}{c}2012 \\
\text { to } \\
2013\end{array}$ & $\begin{array}{c}0 \\
(0 \text { to } 0)\end{array}$ & $\begin{array}{c}251 \\
(107 \text { to } \\
590)\end{array}$ & $\begin{array}{c}315 \\
(191 \text { to } 519)\end{array}$ & $\begin{array}{c}227 \\
(148 \text { to } \\
350)\end{array}$ & $\begin{array}{c}0 \\
(0 \text { to } 0)\end{array}$ & $\begin{array}{c}104 \\
(68 \text { to } \\
161)\end{array}$ & $\begin{array}{l}\text { Marks et } \\
\text { al., } 2017\end{array}$ \\
\hline $\begin{array}{l}\text { Burkina Faso } \\
\text { (Polesgo) }\end{array}$ & $\begin{array}{l}2012 \\
\text { to } \\
2013\end{array}$ & $\begin{array}{c}0 \\
(0 \text { to } 0)\end{array}$ & $\begin{array}{c}1,890 \\
(1,202 \text { to } \\
2,972)\end{array}$ & $\begin{array}{c}485 \\
(263 \text { to } 896)\end{array}$ & $\begin{array}{c}719 \\
(500 \text { to } \\
1,035)\end{array}$ & $\begin{array}{c}107 \\
(46 \text { to } \\
252)\end{array}$ & $\begin{array}{c}383 \\
(274 \text { to } \\
535)\end{array}$ & $\begin{array}{l}\text { Marks et } \\
\text { al., } 2017\end{array}$ \\
\hline
\end{tabular}




\begin{tabular}{|c|c|c|c|c|c|c|c|c|}
\hline Region & Years & \multicolumn{6}{|c|}{ Adjusted Incidence/ 100,000 PYO (95\%CI) ${ }^{\mathrm{a}}$} & \multirow{2}{*}{$\begin{array}{l}\text { Reference } \\
\text { Marks et } \\
\text { al., } 2017\end{array}$} \\
\hline $\begin{array}{l}\text { Ghana (Asante } \\
\text { Akim North) }\end{array}$ & $\begin{array}{c}2011 \\
\text { to } \\
2013\end{array}$ & $\begin{array}{l}120 \\
(49 \text { to } \\
290)\end{array}$ & $\begin{array}{c}1,079 \\
(762 \text { to } \\
1,528)\end{array}$ & $\begin{array}{c}314 \\
(230 \text { to } 430)\end{array}$ & $\begin{array}{c}389 \\
(310 \text { to } \\
486)\end{array}$ & - & - & \\
\hline $\begin{array}{l}\text { Guinea-Bissau } \\
\text { (Bandim) }^{\mathrm{b}}\end{array}$ & $\begin{array}{l}2011 \\
\text { to } \\
2013\end{array}$ & $\begin{array}{c}0 \\
(0 \text { to } 0)\end{array}$ & $\begin{array}{c}53 \\
(13 \text { to } \\
208)\end{array}$ & $\begin{array}{c}18 \\
\text { (5 to } 72)\end{array}$ & $\begin{array}{c}20 \\
(8 \text { to } \\
53)\end{array}$ & $\begin{array}{c}4 \\
(1 \text { to } \\
20)\end{array}$ & $\begin{array}{c}10 \\
(4 \text { to } \\
22)\end{array}$ & $\begin{array}{l}\text { Marks et } \\
\text { al., } 2017\end{array}$ \\
\hline Kenya (Kibera) ${ }^{b}$ & $\begin{array}{l}2012 \\
\text { to } \\
2013\end{array}$ & $\begin{array}{c}148 \\
(48 \text { to } \\
458)\end{array}$ & $\begin{array}{c}490 \\
(264 \text { to } \\
912)\end{array}$ & $\begin{array}{c}489 \\
\text { (338 to } 709)\end{array}$ & $\begin{array}{c}419 \\
(308 \text { to } \\
569)\end{array}$ & $\begin{array}{c}141 \\
(82 \text { to } \\
243)\end{array}$ & $\begin{array}{c}284 \\
(217 \text { to } \\
371)\end{array}$ & $\begin{array}{l}\text { Marks et } \\
\text { al., } 2017\end{array}$ \\
\hline Kenya (Khilifi) $)^{\mathrm{c}}$ & $\begin{array}{l}1998 \\
\text { to } \\
2014\end{array}$ & \multicolumn{6}{|c|}{$0.5 \%$ and $2.1 \%$ of bacteremia in children and adults respectively } & $\begin{array}{c}\text { Muthumbi } \\
\text { et al., } \\
2015\end{array}$ \\
\hline $\begin{array}{l}\text { Madagascar }^{\mathrm{b}} \\
\text { (Imerintsiatosika) }^{\text {Imiation }}\end{array}$ & $\begin{array}{l}2011 \\
\text { to } \\
2013\end{array}$ & $\begin{array}{c}0 \\
(0 \text { to } 0)\end{array}$ & $\begin{array}{c}0 \\
(0-0)\end{array}$ & $\begin{array}{c}171 \\
(181 \text { to } 360)\end{array}$ & $\begin{array}{c}95 \\
(45 \text { to } \\
201)\end{array}$ & $\begin{array}{c}20 \\
(4 \text { to } \\
103)\end{array}$ & $\begin{array}{c}58 \\
(29 \text { to } \\
114)\end{array}$ & $\begin{array}{l}\text { Marks et } \\
\text { al., } 2017\end{array}$ \\
\hline $\begin{array}{l}\text { Madagascar } \\
\text { (Isotry) }\end{array}$ & $\begin{array}{l}2011 \\
\text { to } \\
2013\end{array}$ & $\begin{array}{c}0 \\
(0 \text { to } 0)\end{array}$ & $\begin{array}{c}0 \\
(0 \text { to } 0)\end{array}$ & $\begin{array}{c}62 \\
\text { (11 to 359) }\end{array}$ & $\begin{array}{l}42 \\
(7 \text { to } \\
247)\end{array}$ & $\begin{array}{c}42 \\
(12 \text { to } \\
151)\end{array}$ & $\begin{array}{c}42 \\
(15 \text { to } \\
119)\end{array}$ & $\begin{array}{l}\text { Marks et } \\
\text { al., } 2017\end{array}$ \\
\hline $\begin{array}{l}\text { Malawi } \\
\text { (Blantyre) }\end{array}$ & $\begin{array}{l}1998 \\
\text { to } \\
2014\end{array}$ & \multicolumn{6}{|c|}{$\begin{array}{c}S \text {. Typhi associated with } 1.2 \% \text { of bacteremia; was most common in children and } \\
\text { young adults, with a peak age range of } 5 \text { to } 10 \text { years. Number of Salmonella Typhi } \\
\text { isolated from blood cultures peaked in } 2013 \text { with an incidence of } 207 \text { per 100,000 } \\
\text { population. }\end{array}$} & $\begin{array}{l}\text { Feasey et } \\
\text { al., } 2015\end{array}$ \\
\hline Nigeria (Kano) & $\begin{array}{l}2008 \\
\text { to } \\
2015\end{array}$ & \multicolumn{6}{|c|}{$\begin{array}{c}\text { A study of etiology of bacteremia in febrile children under } 5 \text { yrs: } S \text {. Typhi was } \\
\text { isolated from 280/686 (40.8\%) positive blood cultures. Total children screened }(\mathrm{n}= \\
1944) \text {. }\end{array}$} & $\begin{array}{l}\text { Obaro et } \\
\text { al,, } 2015\end{array}$ \\
\hline $\begin{array}{l}\text { Nigeria (Federal } \\
\text { Capital Territory) }\end{array}$ & $\begin{array}{l}2008 \\
\text { to } \\
2015\end{array}$ & \multicolumn{6}{|c|}{$\begin{array}{l}\text { A study of etiology of bacteremia in febrile children under } 5 \text { yrs: } S \text {. Typhi isolated } \\
\text { from } 84 / 457(18.3 \%) \text { positive blood cultures. Total children screened }(\mathrm{n}=6082) \text {. }\end{array}$} & $\begin{array}{l}\text { Obaro et } \\
\mathrm{al}, 2015\end{array}$ \\
\hline $\begin{array}{l}\text { Sudan (East Wad } \\
\text { Medani) }^{b}\end{array}$ & $\begin{array}{l}2012 \\
\text { to } \\
2013\end{array}$ & $0(0-0)$ & $0(0-0)$ & $0(0-0)$ & $0(0-0)$ & $0(0-0)$ & $0(0-0)$ & $\begin{array}{l}\text { Marks et } \\
\text { al., } 2017\end{array}$ \\
\hline South Africa & $\begin{array}{l}2003 \\
\text { to } \\
2015\end{array}$ & \multicolumn{6}{|c|}{$\begin{array}{l}\text { Data collected as part of national surveillance showed that the annual incidence } \\
\text { rates of typhoid fever subsequent to } 2003 \text { remained low; between } 0.1 \text { and } 0.2 \text { cases } \\
\text { per } 100,000 \text { population }\end{array}$} & $\begin{array}{l}\text { Keddy et } \\
\text { al., } 2018\end{array}$ \\
\hline $\begin{array}{l}\text { Tanzania } \\
(\text { Moshi) })^{b} \text { Rural }\end{array}$ & $\begin{array}{l}2011 \\
\text { to } \\
2013\end{array}$ & $\begin{array}{c}0 \\
(0 \text { to } 0)\end{array}$ & $\begin{array}{c}0 \\
(0 \text { to } 0)\end{array}$ & $\begin{array}{c}18 \\
(8 \text { to } 44)\end{array}$ & $\begin{array}{l}18 \\
(7 \text { to } \\
42)\end{array}$ & $\begin{array}{l}28 \\
(8 \text { to } \\
95)\end{array}$ & $\begin{array}{l}20 \\
(10 \text { to } \\
41)\end{array}$ & $\begin{array}{l}\text { Marks et } \\
\text { al., } 2017\end{array}$ \\
\hline $\begin{array}{l}\text { Tanzania } \\
\left(\text { Moshi) }{ }^{b} \text { Urban }\right.\end{array}$ & $\begin{array}{l}2011 \\
\text { to } \\
2013\end{array}$ & $\begin{array}{c}0 \\
(0 \text { to } 0)\end{array}$ & $\begin{array}{l}1,028 \\
(472 \text { to } \\
2,237)\end{array}$ & $\begin{array}{c}103 \\
\text { (54 to } 199)\end{array}$ & $\begin{array}{c}155 \\
(94 \text { to } \\
256)\end{array}$ & $\begin{array}{c}201 \\
(99 \text { to } \\
408)\end{array}$ & $\begin{array}{c}168 \\
(111 \text { to } \\
253)\end{array}$ & $\begin{array}{l}\text { Marks et } \\
\text { al., } 2017\end{array}$ \\
\hline \multicolumn{9}{|c|}{ Invasive Non typhoidal Salmonella (iNTS) } \\
\hline $\begin{array}{l}\text { Burkina Faso }{ }^{b} \\
\text { (Nioko 11) }\end{array}$ & $\begin{array}{c}2012 \\
\text { to } \\
2013\end{array}$ & $\begin{array}{c}753 \\
(460 \text { to } \\
1,233)\end{array}$ & $\begin{array}{c}753 \\
(460 \text { to } \\
1,233)\end{array}$ & $\begin{array}{c}236 \\
(133 \text { to } 420)\end{array}$ & $\begin{array}{c}475 \\
\text { (352 to } \\
640)\end{array}$ & $\begin{array}{c}35 \\
(13 \text { to } \\
96)\end{array}$ & $\begin{array}{c}237 \\
(178 \text { to } \\
316)\end{array}$ & $\begin{array}{l}\text { Marks et } \\
\text { al., } 2017\end{array}$ \\
\hline $\begin{array}{l}\text { Burkina Faso }{ }^{\mathrm{b}} \\
\text { (Polesgo) }\end{array}$ & $\begin{array}{l}2012 \\
\text { to } \\
2013\end{array}$ & $\begin{array}{c}431 \\
(162 \text { to } \\
1,147)\end{array}$ & $\begin{array}{c}630 \\
(288 \text { to } \\
1,380)\end{array}$ & $\begin{array}{c}0 \\
(0 \text { to } 0)\end{array}$ & $\begin{array}{c}255 \\
\text { (138 to } \\
470)\end{array}$ & $\begin{array}{c}54 \\
(16 \text { to } \\
179)\end{array}$ & $\begin{array}{c}144 \\
(83 \text { to } \\
249)\end{array}$ & $\begin{array}{l}\text { Marks et } \\
\text { al., } 2017\end{array}$ \\
\hline $\begin{array}{l}\text { Ghana (Asante } \\
\text { Akim North) }\end{array}$ & $\begin{array}{l}2011 \\
\text { to } \\
2013\end{array}$ & $\begin{array}{c}1,733 \\
(1,373 \text { to } \\
2,188)\end{array}$ & $\begin{array}{c}1,908 \\
(1,469 \text { to } \\
2,479)\end{array}$ & $\begin{array}{c}147 \\
\text { (93 to } 232 \text { ) }\end{array}$ & $\begin{array}{c}742 \\
\text { (631 to } \\
873)\end{array}$ & - & - & $\begin{array}{l}\text { Marks et } \\
\text { al., } 2017\end{array}$ \\
\hline $\begin{array}{l}\text { Guinea-Bissau } \\
\text { (Bandim) }^{\mathrm{b}}\end{array}$ & $\begin{array}{l}2011 \\
\text { to } \\
2013\end{array}$ & $\begin{array}{c}291 \\
(176 \text { to } \\
482)\end{array}$ & $\begin{array}{c}53 \\
(13 \text { to } \\
208)\end{array}$ & $\begin{array}{c}53 \\
(14 \text { to } 97)\end{array}$ & $\begin{array}{c}116 \\
(69 \text { to } \\
161)\end{array}$ & $\begin{array}{c}0 \\
(0 \text { to } 0)\end{array}$ & $\begin{array}{c}37 \\
(24 \text { to } \\
57)\end{array}$ & $\begin{array}{l}\text { Marks et } \\
\text { al., } 2017\end{array}$ \\
\hline Kenya (Kibera) ${ }^{b}$ & $\begin{array}{l}2012 \\
\text { to } \\
2013\end{array}$ & $\begin{array}{c}49 \\
(7 \text { to } \\
350)\end{array}$ & $\begin{array}{c}49 \\
(7 \text { to } \\
348)\end{array}$ & $\begin{array}{c}17 \\
\text { (2 to } 124)\end{array}$ & $\begin{array}{c}31 \\
(10 \text { to } \\
95)\end{array}$ & $\begin{array}{c}33 \\
(10 \text { to } \\
101)\end{array}$ & $\begin{array}{c}32 \\
(14 \text { to } \\
70)\end{array}$ & $\begin{array}{l}\text { Marks et } \\
\text { al., } 2017\end{array}$ \\
\hline Kenya (Khilifi) ${ }^{c}$ & $\begin{array}{l}1998 \\
\text { to } \\
2014\end{array}$ & \multicolumn{2}{|c|}{$\begin{array}{c}32.6 \\
(28.1 \text { to } 37.7)\end{array}$} & $\begin{array}{c}2.4 \\
(1.49 \text { to } 3.62)\end{array}$ & \multicolumn{3}{|c|}{$\begin{array}{c}1.7 \\
(0.87 \text { to } 3.11)\end{array}$} & $\begin{array}{l}\text { Muthumbi } \\
\text { et al., } \\
2015\end{array}$ \\
\hline
\end{tabular}




\begin{tabular}{|c|c|c|c|c|c|c|c|}
\hline Region & Years & \multicolumn{5}{|c|}{ Adjusted Incidence/ 100,000 PYO $(95 \% \mathrm{CI})^{\mathrm{a}}$} & Referenc \\
\hline Kenya (Kibera) ${ }^{b}$ & $\begin{array}{c}2009 \\
\text { to } \\
2014\end{array}$ & \multicolumn{5}{|c|}{ In children 0 to 4 yrs: 735.2 (622.4 to 868.5 ) and overall 149.8 (128 to 175.2 ) } & $\begin{array}{l}\text { Verani et } \\
\text { al., } 2015\end{array}$ \\
\hline Kenya $\left(\right.$ Lwak) ${ }^{b}$ & $\begin{array}{c}2009 \\
\text { to } \\
2014\end{array}$ & \multicolumn{5}{|c|}{ In children 0 to 4 yrs: $2305.6(2,102.2$ to $2,528.7)$ and overall 471.9 (436.7 to 510) } & $\begin{array}{l}\text { Verani et } \\
\text { al., } 2015\end{array}$ \\
\hline $\begin{array}{l}\text { Madagascar }^{\mathrm{b}} \\
\text { (Imerintsiatosika) }\end{array}$ & $\begin{array}{c}2011 \\
\text { to } \\
2013\end{array}$ & $\begin{array}{c}100 \\
(18 \text { to } \\
562)\end{array}$ & $\begin{array}{c}0 \\
(0 \text { to } 0)\end{array}$ & $\begin{array}{c}18 \\
(3 \text { to } \\
99)\end{array}$ & $\begin{array}{c}0 \\
(0 \text { to } 0)\end{array}$ & $\begin{array}{c}9 \\
(2 \text { to } \\
50)\end{array}$ & $\begin{array}{l}\text { Marks et } \\
\text { al., } 2017\end{array}$ \\
\hline $\begin{array}{l}\text { Madagascar } \\
\text { (Isotry) }\end{array}$ & $\begin{array}{c}2011 \\
\text { to } \\
2013\end{array}$ & $\begin{array}{c}0 \\
(0 \text { to } 0)\end{array}$ & $\begin{array}{c}0 \\
(0 \text { to } 0)\end{array}$ & $\begin{array}{c}0 \\
(0 \text { to } 0)\end{array}$ & $\begin{array}{c}0 \\
(0 \text { to } 0)\end{array}$ & $\begin{array}{c}0 \\
(0 \text { to } 0)\end{array}$ & $\begin{array}{l}\text { Marks et } \\
\text { al., } 2017\end{array}$ \\
\hline $\begin{array}{l}\text { Malawi } \\
\text { (Blantyre) }\end{array}$ & $\begin{array}{c}1998 \\
\text { to } \\
2014\end{array}$ & \multicolumn{5}{|c|}{$\begin{array}{l}\text { iNTS serovars isolates from } 6.1 \% \text { of blood cultures, of which } 79.1 \% \text { were } S \text {. } \\
\text { Typhimurium and } 15.8 \% \text { were } S \text {. Enteritidis. Frequency of iNTS peaked in }<5 \text { yrs } \\
\text { and in } 20 \text { to } 45 \text { yrs age groups. During the study period isolations of } S \text {. Enteritidis } \\
\text { peaked in 2001, and of } S \text {. Typhimurium in } 2003 \text {. }\end{array}$} & $\begin{array}{l}\text { Feasey et } \\
\text { al., } 2015\end{array}$ \\
\hline Nigeria (Kano) & $\begin{array}{l}2008 \\
\text { to } \\
2015\end{array}$ & \multicolumn{5}{|c|}{$\begin{array}{l}\text { A study of etiology of bacteremia in febrile children under } 5 \text { yrs. NTS isolated from } \\
73 / 686(10.6 \%) \text { positive blood cultures. Total children screened }(\mathrm{n}=1,944) \text {. }\end{array}$} & $\begin{array}{l}\text { Obaro et } \\
\text { al., } 2015\end{array}$ \\
\hline $\begin{array}{l}\text { Nigeria (Federal } \\
\text { Capital Territory) }\end{array}$ & $\begin{array}{l}2008 \\
\text { to } \\
2015\end{array}$ & \multicolumn{5}{|c|}{$\begin{array}{l}\text { A study of etiology of bacteremia in febrile children under } 5 \text { yrs. NTS isolated from } \\
26 / 457(5.7 \%) \text { positive blood cultures. Total children screened }(n=6,082) \text {. }\end{array}$} & $\begin{array}{l}\text { Obaro et } \\
\text { al., } 2015\end{array}$ \\
\hline $\begin{array}{l}\text { Sudan (East Wad } \\
\text { Medani) }^{\text {b }}\end{array}$ & $\begin{array}{l}2012 \\
\text { to } \\
2013\end{array}$ & $\begin{array}{c}0 \\
(0 \text { to } 0)\end{array}$ & $\begin{array}{c}0 \\
(0 \text { to } 0)\end{array}$ & $\begin{array}{c}0 \\
(0 \text { to } 0)\end{array}$ & $\begin{array}{c}0 \\
(0 \text { to } 0)\end{array}$ & $\begin{array}{c}0 \\
(0 \text { to } 0)\end{array}$ & $\begin{array}{l}\text { Marks et } \\
\text { al., } 2017\end{array}$ \\
\hline $\begin{array}{l}\text { South Africa } \\
\text { (Gauteng } \\
\text { Province) }\end{array}$ & $\begin{array}{l}2003 \\
\text { to } \\
2013\end{array}$ & \multicolumn{5}{|c|}{$\begin{array}{l}\text { Incidence of iNTS per 100,000 population/year dropped from } 5.0 \text { (2003) to } 2.2 \\
\qquad(2013)\end{array}$} & $\begin{array}{l}\text { Keddy et } \\
\text { al., } 2017\end{array}$ \\
\hline $\begin{array}{l}\text { Tanzania } \\
(\text { Moshi) })^{b} \text { Rural }\end{array}$ & $\begin{array}{l}2011 \\
\text { to } \\
2013\end{array}$ & $\begin{array}{c}0 \\
(0 \text { to } 0)\end{array}$ & $\begin{array}{c}0 \\
(0 \text { to } 0)\end{array}$ & $\begin{array}{c}0 \\
(0 \text { to } 0)\end{array}$ & $\begin{array}{l}28 \\
\text { (8 to } \\
95)\end{array}$ & $\begin{array}{c}7 \\
(2 \text { to } \\
23)\end{array}$ & $\begin{array}{l}\text { Marks et } \\
\text { al., } 2017\end{array}$ \\
\hline $\begin{array}{l}\text { Tanzania } \\
(\text { Moshi) })^{\mathrm{b}} \text { Urban }\end{array}$ & $\begin{array}{c}2011 \\
\text { to } \\
2013\end{array}$ & $\begin{array}{c}427 \\
(125 \text { to } \\
1,461)\end{array}$ & $\begin{array}{c}0 \\
(0 \text { to } 0)\end{array}$ & $\begin{array}{c}0 \\
(0 \text { to } 0)\end{array}$ & $\begin{array}{c}0 \\
(0 \text { to } 0)\end{array}$ & $\begin{array}{c}19 \\
(5 \text { to } \\
64)\end{array}$ & $\begin{array}{l}\text { Marks et } \\
\text { al., } 2017\end{array}$ \\
\hline
\end{tabular}

${ }^{\mathrm{a}}$ Adjusted Incidence/ 100,000 PYO (95\% CI) included unless otherwise described; ${ }^{\mathrm{b}}$ The incidence rate / 100,000 person year of observation (PYO) was adjusted for health-seeking behavior; ${ }^{\mathrm{c}}$ Adjustment based on missed blood cultures and contamination rate per age group.

Table 2. Asia: Salmonella enterica serovar Typhi, Paratyphi (A, B, C) Burden

\begin{tabular}{|c|c|c|c|}
\hline Region & Year & $\begin{array}{c}\text { Burden Incidence/100,000 Person/Years } \\
\text { (Unless Otherwise Noted) }\end{array}$ & Reference \\
\hline \multicolumn{4}{|c|}{ S. Typhi } \\
\hline $\begin{array}{l}\text { Bangladesh } \\
\text { (Dhaka) }\end{array}$ & $\begin{array}{l}2003 \text { to } \\
2004\end{array}$ & $\begin{array}{l}1050(95 \% \text { CI } 680 \text { to } 1550)(<5 \text { yrs }) \\
90(95 \% \text { CI } 50 \text { to } 140)(>5 \text { yrs }) \\
200(95 \% \text { CI } 150 \text { to } 280) \text { (Overall })\end{array}$ & Naheed et al., 2010 \\
\hline $\begin{array}{l}\text { Bangladesh } \\
\text { (Dhaka) }\end{array}$ & $\begin{array}{l}2001 \text { and } \\
2014\end{array}$ & $\begin{array}{c}0.9 \text { to } 3.9 \% \text { and } 3.3 \text { to } 8.8 \% \\
\text { Retrospective analysis of blood culture positivity rates from } 3 \\
\text { hospitals }\end{array}$ & Saha et al., 2018 \\
\hline
\end{tabular}




\begin{tabular}{|c|c|c|}
\hline Region & Year & $\begin{array}{l}\text { Burden Incidence/100,000 Person/Years } \\
\text { (Unless Otherwise Noted) }\end{array}$ \\
\hline China (Hechi) & $\begin{array}{l}2001 \text { to } \\
2002\end{array}$ & $\begin{array}{l}15.3 / 100,000(5 \text { to } 60 \mathrm{yrs}) \\
29.3 / 100,000(5 \text { to } 15 \mathrm{yrs}) \\
12.4 / 100,000(>16 \mathrm{yrs})\end{array}$ \\
\hline India & $\begin{array}{l}1950 \text { to } \\
2015\end{array}$ & $\begin{array}{c}9.7 \% \text { (95\% CI } 5.7 \text { to } 16 \%) \text { prevalence rate } \\
\text { of in hospital based studies, with Systematic and Meta-analysis } \\
377 \text { (95\% CI } 178 \text { to } 801) / 100,000 \text { patient year pooled incidence rate } \\
\text { from community based studies from Delhi and Kolkata. }\end{array}$ \\
\hline India (Kolkata) & $\begin{array}{l}2003 \text { to } \\
2004\end{array}$ & $\begin{array}{l}\text { 214.2/100,000/year (overall) } \\
\text { 89.2/100,000/year ( } 0 \text { to } 1 \mathrm{yr}), \\
\text { 340.1/100,000/year ( } 2 \text { to } 4 \text { yrs), } \\
\text { 493.5/100,000/year ( } 5 \text { to } 15 \mathrm{yrs} \text { ) } \\
\text { 119.7/100,000/year (>16 yrs). }\end{array}$ \\
\hline India (New Delhi) ${ }^{\mathrm{a}}$ & $\begin{array}{l}2010 \text { to } \\
2015\end{array}$ & $0.62 \%$ to $0.18 \%$ \\
\hline India (Vellor) ${ }^{\mathrm{a}}$ & $\begin{array}{l}2010 \text { to } \\
2015\end{array}$ & $1.38 \%$ to $0.17 \%$ \\
\hline India (Mumbai) ${ }^{\mathrm{a}}$ & $\begin{array}{c}2010 \text { to } \\
2015\end{array}$ & $0.4 \%(2010)$ and $0.2 \%(2015)$ \\
\hline $\begin{array}{l}\text { Indonesia (North } \\
\text { Jakarta) }\end{array}$ & $\begin{array}{l}2002 \text { to } \\
2003\end{array}$ & $\begin{array}{c}\text { 81.7/100,000/year (overall) } \\
\text { 0/100,000/year ( } 0 \text { to } 1 \mathrm{yr}), \\
\text { 148.7/100,000/year (2 to } 4 \text { yrs), } \\
\text { 180.3/100,000/year ( } 5 \text { to } 15 \text { yrs) and } \\
51.2 / 100,000 / \text { year (>16 yrs). }\end{array}$ \\
\hline Pakistan (Karachi) & $\begin{array}{l}2002 \text { to } \\
2004\end{array}$ & $\begin{array}{l}573.2 / 100,000 / \text { year ( } 2 \text { to } 5 \text { yrs) } \\
412.9 / 100,000 \text { /year ( } 5 \text { to } 15 \text { yrs) }\end{array}$ \\
\hline $\begin{array}{l}\text { Pakistan (Karachi, } \\
\text { Lahore, Islamabad) }\end{array}$ & $\begin{array}{l}1992 \text { and } \\
2015\end{array}$ & $\begin{array}{c}6.42 \% \text { and } 1.32 \% \\
\text { Review of laboratory data from } 3 \text { tertiary care hospitals showed a } \\
\text { decrease in } S \text {. Typhi positive blood culture rate from }\end{array}$ \\
\hline Nepal (Khatmandu) & $\begin{array}{l}2008 \text { to } \\
2012\end{array}$ & $\begin{array}{l}2 \text { to } 8 \% \text { blood culture positivity rate for } S \text {. Typhi. Retrospective } \\
\text { analysis of patients presenting with fever to } 11 \text { hospital reporting. }\end{array}$ \\
\hline Thailand & $\begin{array}{l}2003 \text { and } \\
2014\end{array}$ & $\begin{array}{l}\text { 8.6 cases } / 100,000 \\
3.0 \text { cases } / 100,000 \\
\text { Based on national surveillance data the incidence of typhoid fever } \\
\text { reported to have decreased }\end{array}$ \\
\hline $\begin{array}{l}\text { Vietnam (Nation } \\
\text { wide) }\end{array}$ & $\begin{array}{c}1999 \text { to } \\
2003\end{array}$ & $\begin{array}{l}14.7 / 100,000 \\
(>100 / 100,000 \text { high incidence in } 2 \text { provinces (Soc Trang and Dien } \\
\text { Bien) and } \\
(>10<100 / 100,000 \text { lower incidence in } 18 \text { other provinces). }\end{array}$ \\
\hline Vietnam (Hue) & $\begin{array}{l}2002 \text { to } \\
2004\end{array}$ & $\begin{array}{l}21.3 / 100,000 \text { (overall) } \\
24.2 / 100,000 \text { ( } 5 \text { to } 15 \text { yrs }) \\
10.9 / 100,000 \text { (>16 yrs). }\end{array}$ \\
\hline $\begin{array}{l}\text { Vietnam (Ho Chi } \\
\text { Minh City) }\end{array}$ & $\begin{array}{l}1994 \text { and } \\
2015\end{array}$ & $\begin{array}{l}\qquad \begin{array}{c}12.3 \% \text { and } 0.07 \% \\
\text { blood culture positivity rate. }\end{array} \\
\text { in an infectious diseases hospital in Ho Chi Minh City, Review of } \\
\text { published reports suggest a decreasing burden of } S \text {. Typhi. }\end{array}$ \\
\hline
\end{tabular}

Reference

Ochiai et al., 2008

John et al., 2016

Ochiai et al., 2008

Balaji et al., 2018

Balaji et al., 2018

Balaji et al., 2018

Ochiai et al., 2008

Ochiai et al., 2008

Das et al., 2018

Bajracharya et al., 2014

Techasaensiri et al., 2018

Cuong, 2011

Ochiai et al., 2008

Nga et al., 2012;

Nga et al., 2018

S. Paratyphi A, B, C

\begin{tabular}{lc}
\hline $\begin{array}{l}\text { Bangladesh } \\
\text { (Dhaka) }\end{array}$ & 2003 to \\
Bangladesh & 2004 \\
(Dhaka) & 2001 and \\
& 2014
\end{tabular}

India
1950 to

2015
40 (95\% CI 20 to 80)

0.2 to $0.8 \%$ and 0.75 to $3 \%$

Retrospective analysis of blood culture positivity rates from 3 hospitals:

105 (95\% CI 74 to 148)/ 100,000 patient year

pooled incidence rate of from community based studies from Kolkata.

$0.9 \%$ (95\% CI 0.5 to $1.7 \%)$ prevalence rate

Systematic review and Meta-analysis in hospital based studies $1.29 \%$ and $0.39 \%$

Pakistan (Karachi, 1992 and Review of laboratory data from 3 large medical centers showed that Lahore, Islamabad) $2015 \quad$ blood culture positivity for Salmonella enterica Para A and B decreased

Naheed et al., 2010

Saha et al., 2018

John et al., 2016

Das et al., 2018 


\begin{tabular}{|c|c|c|c|}
\hline Region & Year & $\begin{array}{c}\text { Burden Incidence/100,000 Person/Years } \\
\text { (Unless Otherwise Noted) }\end{array}$ & Reference \\
\hline Nepal (Khatmandu) & $\begin{array}{l}2008 \text { to } \\
2012\end{array}$ & $\begin{array}{l}\text { 2 to } 3 \% \\
\text { blood cultures positive for } S \text {. Paratyphi } \\
\text { Retrospective analysis of data in patients presenting with fever to } \\
11 \text { hospital reporting. }\end{array}$ & $\begin{array}{l}\text { Bajracharya et al., } \\
\qquad 2014\end{array}$ \\
\hline Thailand & $\begin{array}{l}2007 \text { and } \\
2009\end{array}$ & $\begin{array}{l}0.41 \text { and } 0.77 \text { cases } / 100,000 \text { persons/year } \\
\text { Based on national surveillance data the incidence of paratyphoid } \\
\text { fever remained stable during the study period }\end{array}$ & $\begin{array}{l}\text { Techasaensiri et al., } \\
2018\end{array}$ \\
\hline
\end{tabular}

${ }^{a}$ Laboratory data in 3 large medical centers reviewed to investigate proportion of $S$. Typhi positive blood culture.

In high income settings such as Western Pacific Region (Australia, Brunei, Japan, New Zealand and Singapore) Salmonella infections are primarily associated with gastrointestinal rather than invasive disease. Estimates from 2010 suggested that salmonellae contributed to $1 \%$ of waterborne gastrointestinal infections (Gibney et al., 2017). In the USA, 1872 cases of $S$. Typhi and 467 cases of $S$. Paratyphi were reported between 2008 and 2012 (Date et al., 2016), although the majority were travel associated.

Notably Salmonella strains show geographical differences. The Non-typhoidal salmonellae (NTS) associated with invasive disease in Southern Africa are reported to be $S$. Typhimurium and S. Enteritidis with Salmonella Typhimurium pathotype ST313 primarily seen to be associated with invasive disease and febrile illness (Kariuki and Onsare, 2015). On the other hand, in the Lao People's Democratic Republic, studies of isolates collected between 2000 and 2012 showed the most frequent isolates associated with both non-invasive and invasive nontyphoidal salmonella (iNTS) disease included S. Enteritidis, $S$. Typhimurium as well as S. Choleraesuis (Le Thi Phuong, 2017).

The strains can evolve and change over time within countries and regions. Studies conducted in Nepal suggested that, in 2005-2006, several distinct genotypes of $S$. Typhi were present. More recent findings, however, show that this heterogeneity of genotypes, particularly in children under five, is now reduced. Such change is linked to ongoing clonal expansion of the S. Typhi H58 lineage. Further analyses reveal a shift in dominance from $\mathrm{H} 58$ Lineage I to H58 Lineage II, with the latter being significantly more common after 2010. Such change is likely due to spread from other South Asian Countries (Britto et al., 2018).

NTS are mainly associated with diarrhoeal infection. The first global estimates of the disease burden 1990-2010 reported that of all foodborne diseases, diarrheal and invasive infections due to non-typhoidal $S$. enterica infections resulted in the highest burden, causing 4.07million (95\% uncertainty interval (UI) 2.49-6.27 million) Disability-Adjusted Life Years (Kirk et al., 2015).

A more recent Global burden of diseases study 2015 (Collaborators, 2017) reinforces that finding and estimates that, globally, Rota virus, Shigella and Salmonella were among the top three causes of diarrhoeal deaths, with Salmonella infection contributing 90,300 deaths (95\% UI $34,100-183,100)$.

\subsubsection{Symptomology}

Clinical features of enteric infections, including their complications and outcomes, differ between adults and children. Even among children, differences exist between infants and older children as well as between children in Africa and Asia (Azmatullah et al., 2015). The typical presentation is fever 5-15 days after exposure. Fever may be accompanied by gastrointestinal features and these can vary from diarrhoea, which is more common in infants, to constipation. Abdominal pain and nausea are more frequent in adults. Complications include gastrointestinal bleeds and perforations, which are related to the robust immune response and hence more common in older children and adults, while younger children are more likely to develop a paralytic ileus. Additional complications include seizures, cardiopulmonary disorders (myocarditis, endocarditis, pericarditis, and pericardial effusion) as well as bronchopneumonia. Transient pancytopenia in acute stage related to seeding of $S$. Typhi to the bone marrow is also recognized (Mai et al., 2003; Britto et al., 2017). Children in Africa have a higher risk of developing anaemia and thrombocytopenia relative to children from Asia (Azmatullah et al., 2015). Typhoid may also be associated with sepsis. A multinational study on causes of sepsis in Southeast Asia reported that $0.2 \%$ of sepsis cases were related to $S$. Typhi (Southeast Asia Infectious Disease Clinical Research Network, 2017).

While NTS are classically associated with gastrointestinal infections, in immunocompromised patients there is increasing recognition of their role in invasive disease. However, genomic differences in strains may also account for the difference in invasive versus enterocolitic manifestations, and influence host immune response, and these differences are subjects of active research (Gal-Mor et al., 2014).

Between 2003 and 2013, 278 cases of meningitis due to NTS (of which $44.5 \%(n=106)$ were due to Salmonella Typhimurium) were detected through a laboratory-based surveillance in South Africa and were shown to be 
significantly associated with HIV disease (Keddy et al., 2015). Similar association of iNTS with HIV and sickle cell disease has been reported from Kenya. Analysis of these 192 iNTS isolates obtained 2005-2013, 114 were shown to be Typhimurium and 78 Enteritidis. Salmonella Typhimurium pathotype ST313 was primarily seen to be associated with invasive disease and febrile illness (Kariuki and Onsare, 2015). Use of antiretroviral therapy has been associated with reduction in disease due to invasive NTS (Keddy et al., 2017). These reports are supported by a recent literature review, spanning 1966-2014, which reported NTS as being responsible for up to $39 \%$ of community-acquired blood stream infections in subSaharan Africa (Uche et al., 2017). In Southeast Asia, 21\% of sepsis is associated with invasive NTS (Southeast Asia Infectious Disease Clinical Research Network, 2017).

\subsection{Taxonomic Classification}

The genus Salmonella is included in the family Enterobacteriaceae, order Enterobacteriales (Adeolu et al., 2016). The taxonomy of salmonellae has evolved over the last quarter of a century towards a modern classification based on DNA-DNA homology (Popoff et al., 2004). Currently the genus Salmonella has two species: Salmonella enterica and Salmonella bongori. Six S.enterica subspecies are also recognized; Salmonella enterica subspecies: enterica (I), salamae (II), arizonae (IIIa), diarizonae (IIIb), houtenae (IV), indica (VI) (Alikhan et al., 2018; Brenner et al., 2000; Johnson, 2018). Salmonella enterica subspecies are further sub-classified as 'serovars' based on the antigenic structure and reactivity. Subspecies I of Salmonella enterica, also known as Salmonella enterica subspecies enterica, contains many of the medically important human pathogens; however, rare infections with other subspecies have been reported.

The first compilation of classification based on antigenic structure, the Kauffman-White-Le Minor (KWL), scheme remains widely used as the gold standard for strain typing. This classification is based on the antigenic structure of salmonellae. The bacterium has somatic " $\mathrm{O}$ " and flagellar " $\mathrm{H}$ " antigens with significant variation in antigenic composition that allows identification in the laboratory based on antigen-based agglutination tests. The $\mathrm{O}$ antigen is the polysaccharide constituent of the lipopolysaccharide (LPS) of the bacterial cell wall; where a single bacterium may express more than one antigenic type of $\mathrm{O}$ on its cell surface (Wattiau et al., 2011). By contrast, only one " $\mathrm{H}$ " flagellar antigen is expressed on the bacterial cell's surface at any one time. However, the Salmonella genome may encode for 2 (mostly) or up to 3-4 flagellar antigens, where cultures in the laboratory can exhibit a switching of flagellar antigens called phase variation. Serovars determined by antigenic serotyping (antibody agglutination) in the laboratory are named in the KWL scheme, which is maintained by the WHO collaborating Center for Reference and Research on Salmonella. Updates for addition of new emerging variants to the latest classification scheme of 2007 were proposed in a research paper in 2014 (Issenhuth-Jeanjean et al., 2014).
The diversity, and phase variation of antigens in Salmonella have made antigenic classification difficult. Molecular typing based on genes encoding for $\mathrm{O}$ and $\mathrm{H}$ antigens has been performed (Wattiau et al., 2011). Further, many molecular methods with improved discrimination have also been proposed to replace serotyping (Alikhan et al., 2018). The genome structures of several medically important salmonellae are now accessible in GenBank, which could inform more specific molecular-based typing methods. However, due to labour and cost demands, KWL schemebased serotyping remains in use. Many clinical laboratories shorten this serotyping scheme to perform a few agglutination reactions to identify the most common serotypes. Application of rapid methods including Matrix Assisted Laser Desorption Ionisation Time-of-Flight (MALDI-TOF) Mass Spectrometry, and molecular methods such as Pulsed Field Gel Electrophoresis (PFGE), Multilocus Sequence Typing (MLST), and Multiple-Locus Variable-Number Tandem Repeat Analysis (MVLA) also enable typing, but these methods have varying accuracy and discriminatory ability. Rare and emerging serotypes are still only identifiable in reference laboratories through either exhaustive antigenic serotyping or molecular serotyping. Such methods are necessary to establish new pathogenic serotypes, detect and confirm outbreaks, and delineate epidemiology.

\subsubsection{Pathogenic salmonellae}

Salmonellae have a widely-distributed host range including both human and animal species. Two distinct disease processes are known in humans: invasive and noninvasive. Non-invasive infections manifest most commonly as gastroenteritis, whereas invasive infections comprise bacteremia - including the syndrome of 'enteric fever' - and meningitis. Enteric fever pathogens, also known as typhoidal salmonellae, are restricted to human hosts and have no animal reservoir (Eng et al., 2015). Other zoonotic salmonellae occasionally cause invasive infections in immunocompromised hosts. Typhoidal salmonellae include: Salmonella enterica serovars Typhi, Paratyphi A, Paratyphi $\mathrm{B}$, and Paratyphi C. Reasons for the predilection of typhoidal salmonellae to cause invasive bacteremic infections remain putative; however, the consensus leans toward their avoidance of the human natural immunity by suppression of neutrophilic killing as one of the major escape mechanisms leading to invasiveness (Hiyoshi et al., 2018).

Non-typhoidal salmonellae (NTS), while occasionally responsible for invasive infections in those with weak immunity, mostly induce gastrointestinal inflammation leading to gastroenteritis. Although many new serovars are increasingly recognized, more commonly identified ones are Salmonella enterica subspecies enterica serovar Enteritidis (Salmonella Enteritidis), and Salmonella enterica subspecies enterica serovar Typhimurium (Salmonella Typhimurium). Several emerging strains causing zoonotic and foodborne salmonellosis among humans have been described. Among the more common ones observed in the 2000-2007 WHO analysis of data from quality assured laboratories are: Infantis, Agona, 
Heidelberg, Virchow, Newport, Hadar, Montevideo, and Saintpaul (Hendriksen et al., 2011).

\subsection{Transmission}

Transmission routes and reservoirs are important control points for salmonelloses and therefore an understanding of these epidemiological aspects is essential to devise control measures to prevent illness.

Salmonellae enter their hosts through the gastrointestinal tract and multiply therein to either cause inflammation directly (resulting in gastroenteritis) or invade the intestinal epithelium to establish systemic illness (Pegues and Miller, 2010). The route of transmission is therefore fecal-oral, with reservoirs propagating the cycle through fecal shedding and hosts becoming infected through oral intake. The primary reservoirs for salmonellae are gastrointestinal tracts of vertebrates, with environmental contamination occurring through shedding of bacteria in feces (Kingsley and Baumler, 2000). Transmission is facilitated and sustained through environmental reservoirs such as contaminated food, water, and soil, although direct transmission through contaminated hands (with feces from human or animal hosts) also occurs. This environmental transmission is enabled by the prototrophic nature of salmonellae; they require little or no nutrients to thrive in environmental or food reservoirs (Rhodes and Kator, 1988).

One important feature of Salmonella transmission cycle is asymptomatic fecal shedding by vertebrate hosts. This occurs in both animals and humans, usually following an infection, and continuing in the recovery phase (Gopinath et al., 2012). This shedding may continue in the long term, giving rise to 'salmonella carriers' or chronic excretors in the population that serve as important reservoirs of infection. Based on murine models of $S$. Typhimurium, it has been proposed that transmission is reinforced due to 'super-shedders' in the population, excreting larger amounts of the organisms in their feces due to persistent inflammation and high abundance of organisms in the intestinal lumen (Monack, 2012).

Asymptomatic NTS carriage rate of $2.0-2.9 \%$ in the general populations, with $4.4 \%$ reported amongst chicken farmers in Vietnam (Trung et al., 2017). While the exact pathogenesis of persistence is unclear, a long term followup of NTS cases in Israel showing an overall persistence rate of $2.2 \%$ suggests that $65 \%$ of the persistent cases had experienced prolonged symptoms and relapsing diarrhoea (Marzel et al., 2016).

Since NTS have a wider host range, transmission is efficiently maintained through multiple direct and indirect routes where zoonotic reservoirs are present. NTS gastroenteritis is recognized as predominantly a food-borne illness, although water remains an environmental source leading to food contamination (Hohmann, 2001). Where the zoonotic reservoirs are food animals, transmission occurs through contaminated food as vehicles: poultry, eggs, pork, fish, shellfish, beef, milk, and dairy products (Carrasco et al., 2012). Where domestic or companion animals are in contact with fresh produce, fresh fruit and vegetables, and juices contaminated with animal feces are efficient vehicles of transmission. Where such raw material is used in preparation of packaged foods, retail food products that become contaminated also act as sources of transmission and can lead to significant outbreaks due to centralized large-scale production (Tauxe, 1991). In all such instances, poor sanitation practices, poor population hygiene, and poor manufacturing and packaging practices instigate the transmission cycle. Use of water contaminated with NTS for irrigation in horticulture and to wash fresh produce also leads to propagation (Islam et al., 2004), as a variety of salmonellae have been recovered from surface water and groundwater sources (Levantesi et al., 2012).

Recent evidence also suggests that invasive vs diarrheal strains of salmonellae are distinct genotypically and phenotypically, and differentially adapted to environmental reservoirs (MacKenzie et al., 2019). Mutations altering biofilm formation in strains affect adaptability to environmental reservoirs, and strains causing invasive disease have been found to 'switch off' biofilm genes. The triggers and possible therapeutic and engineering control implications of this phenotypic difference between invasive and gastroenteritis-causing strains require further study.

As highlighted earlier, typhoidal salmonellae are exclusively adapted to human hosts and therefore transmission cycles are also restricted to humans. In contrast to NTS, typhoidal salmonellae are not considered primarily foodborne, but also understood to spread through drinking water. Presence of $S$. Typhi in drinking water, surface water and groundwater has been demonstrated as well as linked with outbreaks (Gauld et al., 2019; Qamar et al., 2018). Potable water contaminated with human feces or sewage therefore serves as a critical link in the transmission chain with potential to serve as a hazard control point (Dewettinck et al., 2001).

The incubation period of most salmonelloses is 12 to 72 hours, but may be as long as one week (Humphrey, 2000). However, when the infective dose is high, incubation periods of as short as 2.5 hours have been observed. Both NTS and typhoidal salmonellae have been subjected to volunteer studies to establish infective doses. Earlier studies carried out three quarters of a century ago demonstrated infective doses as high as 100,000 cells of NTS to establish infection in volunteers with later studies demonstrating an even higher required dose. Such doses are unlikely to occur in food or water, and practically smaller doses can establish infection as bacteria are protected by food particles. Typically, infective doses associated with dairy, chocolate, and processed meat are lower due to inherent capacity to inactivate and overcome the host stomach acid barrier. Individuals with impaired gastric acidity are therefore at higher risk of contracting illness (Humphrey, 2000).

The presence of salmonellae in aquatic environments due to contamination with human and animal excreta is an important instigator of the natural transmission cycle. Precautions taken at the consumer level or population level 
to minimize food contamination are therefore necessary to prevent human infections.

\subsection{Population and Individual Control Measures}

In addition to the high burden of typhoid fever in many parts of the world, growing antimicrobial resistance in Salmonella Typhi is a major concern (Bhutta et al., 2018a; 2018b). Recent reports of XDR Typhi strains that are resistant to first line agents (Cotrimoxazole, Ampicillin, Chloramphenicol) as well as to flouroquinolones and to third generation cephalosporins has raised alarm bells. In settings where these strains prevail, treatment options are limited to Azithromycin and carbapenems (Klemm et al., 2018). Azithromycin resistance has also been reported
(Ahsan and Rahman, 2018) and the possibility of XDR Typhi acquiring additional resistance to Azithromycin is a feasible concern.

In view of increasing limited treatment options, efforts to control the spread of the disease within communities requires urgent attention. Major control strategies include; vaccination and hygiene efforts.

\subsubsection{Vaccines}

1.4.1.1 S. Typhi vaccines

Currently three vaccines are recommended for $S$.Typhi (WHO, 2018a, 2018b) (Table 3).

Table 3. Vaccines for S. Typhi (Adapted from WHO, 2018a)

\begin{tabular}{|c|c|c|c|c|}
\hline Vaccine & Vaccine Composition & Administration & Efficacy & Duration of protection \\
\hline $\begin{array}{l}\text { Typhoid } \\
\text { conjugate } \\
\text { vaccine (TCV) }\end{array}$ & $\begin{array}{l}\text { Vi polysaccharide } \\
\text { antigen linked to } \\
\text { tetanus toxoid protein } \\
\text { (also referred to as Vi- } \\
\text { TT conjugate vaccine) }\end{array}$ & $\begin{array}{l}\text { Intramuscular; } \\
\text { single dose }(0.5 \\
\text { mL) in Adults } \\
\text { and children }>6 \\
\text { months to }<45 \\
\text { years of age. }\end{array}$ & $\begin{array}{l}\text { Vaccine "sero- } \\
\text { efficacy": } 85 \text { to } \\
87 \% \text { [95\% CI: } \\
80 \text { to } 88 \text { ] } \\
\text { Voysey and } \\
\text { Pollard, 2018; } \\
\text { Jin et al., } 2017\end{array}$ & $\begin{array}{l}\text { Evidence suggests protection may persist for up } \\
\text { to } 5 \text { years after primary immunization. }\end{array}$ \\
\hline $\begin{array}{l}\text { Unconjugated } \\
\text { Vi } \\
\text { polysaccharide } \\
\text { (ViPS) }\end{array}$ & $\begin{array}{l}\text { Purified Vi capsular } \\
\text { polysaccharide from } \\
\text { the Ty2 } S \text {. Typhi } \\
\text { strain. }\end{array}$ & $\begin{array}{l}\text { Intramuscular/ } \\
\text { subcutaneous, } \\
\text { single dose. } \\
\text { Adults and } \\
\text { children }>2 \\
\text { years of age }\end{array}$ & $\begin{array}{c}\text { Effectiveness } \\
\text { in children } \\
\text { aged } 5 \text { to } 16 \\
\text { years: } 57 \% \\
\text { [95\% CI: } 6 \text { to } \\
\text { 81] Khan et al., } \\
\text { 2012; Sur et } \\
\text { al., } 2009\end{array}$ & Revaccination recommended every 3 years \\
\hline $\begin{array}{l}\text { Live } \\
\text { attenuated } \\
\text { Ty21a }\end{array}$ & $\begin{array}{l}\text { A live attenuated Ty2 } \\
\text { strain of } S \text {. Typhi in } \\
\text { which several genes } \\
\text { have been attenuated. } \\
\text { The resulting vaccine } \\
\text { strain, termed Ty21a, } \\
\text { lacks the Vi antigen }\end{array}$ & $\begin{array}{l}\text { Enteric coated } \\
\text { capsules } \\
\text { administered } \\
\text { orally: } 3 \text { doses } \\
\text { every second } \\
\text { (alternate) day. } \\
\text { (USA and } \\
\text { Canada } 4 \\
\text { doses). } \\
\text { Adults and } \\
\text { children }>6 \\
\text { years of age. }\end{array}$ & $\begin{array}{c}\text { Efficacy for } 3 \\
\text { oral doses of } \\
\text { Ty21a: } 67 \text { to } \\
80 \% \text { [95\% CI: } \\
16 \text { to 95] } \\
\text { Jin et al., 2017; } \\
\text { Darton et al., } \\
\text { 2016; Levine } \\
\text { et al., } 1999\end{array}$ & $\begin{array}{c}\text { Australia and Europe recommend re-vaccination } \\
\text { every } 3 \text { years for people living in endemic areas, } \\
\text { and yearly for travelers to these areas. } \\
\text { While USA recommends vaccination after } 5 \\
\text { years and Canada after } 7 \text { years in people at } \\
\text { exposure risk. }\end{array}$ \\
\hline
\end{tabular}

Currently there are no approved vaccines for Paratyphoid. Protection against $S$. Paratyphi B following Ty21a vaccine was reported in a large scale trial in Santiago, Chile (Levine et al., 1999). This finding however has not been confirmed by other studies. Ty21a vaccination was further shown not to confer protection against $S$. Paratyphi A in a trial in Indonesia (Simanjuntak et al., 1991).

\subsubsection{NTS vaccines}

The increasing realization of the high burden of invasive
NTS disease and associated morbidity, particularly in Africa, has triggered efforts towards developing a vaccine for these infections (Tennant et al., 2016). These efforts have been encouraged by findings suggesting that antibodies against NTS protect against invasive NTS disease (Gordon, 2011). A number of vaccine candidates targeting $S$. Typhimurium and $S$. Dublin are in the process of development (Haselbeck et al., 2017). However, NTS vaccine efforts face challenges including paucity of NTS disease data from Asia and South America. The major challenge though is the large number of NTS serovars circulating, raising concerns that strains targeted by a 
vaccine would be replaced by other circulating strains. In other words, there is concern that widespread use of a vaccine against $S$. Typhimurium and $S$. Enteritidis would result in serovar replacement, e.g., by $S$. Dublin (Haselbeck et al., 2017).

\subsubsection{Hygiene measures}

Intake of unsafe water and contaminated food has been implicated in several outbreaks of typhoid fever (Luby, 2018). Contamination of municipal water or borehole water with sewage or other contaminated water is well recognized to contribute to spread of typhoid in many settings (Baker et al., 2011). Given the role of contaminated water and food in transmission of Salmonella, access to safe water, adequate sanitation as well as food safety including hygiene among food handlers are important pillars of typhoid control.

Improvements to water supplies, including filtration and chlorination, have been shown to reduce the burden of typhoid fever and lead to its elimination. In an outbreak in Tajikistan in 1997 associated with inadequate treatment of municipal water supplies, the re-introduction of chlorinated water supplies was effective in leading to a marked decline in typhoid fever cases (Mermin et al., 1999).

Similarly, the Metropolitan Region of Chile faced a large outbreak of typhoid fever from 1975-1983. In response, between 1983 and 1984 the country instituted a number of measures to prevent the spread of enteric fever. These included typhoid vaccination, treatment of chronic $S$. Typhi carriers, and educational campaigns about hygienic handling of crops and food. In 1991, as part of efforts to control cholera, crop irrigation with sewage contaminated water was stopped, leading to improvement of water quality and irrigation practices. New irrigation channels were constructed to avoid sewage discharge and water channels were chlorinated. Human activity near water sources was prohibited and sanitary barriers were established (Marco et al., 2018). Impact analysis suggests that interruption of person to person transmission through the 1983-1984 measures reduced disease rates by $51 \%$. However, introduction of environmental measures in 1991; through control of irrigation waters and crop cultivation and interrupting the contact of sewage-contaminated items with the public led to a $77 \%$ decline in typhoid fever. This decline has continued so that today the typhoid fever is rare in the region (Marco et al., 2018).

Evidence therefore points to a need for a multipronged approach to controlling diseases associated with Salmonella enterica serovars Typhi, Paratyphi A, Paratyphi $B$, and Paratyphi $C$ as well as with NTS serovars. Access to safe water and food, as well as improved sanitation and sewage disposal, are key. These measures need to be implemented along with a system aimed at early case detection with appropriate treatment and vaccination of at risk populations.

\subsection{Environmental Occurrence and Persistence}

\subsection{Detection Methods}

\subsubsection{Culture-based methods}

Salmonellae are gram-negative, flagellated, non-lactose fermenting, facultative anaerobic bacilli, of which most are motile. Most of the Salmonella serovars grow at a temperature range of $5-47^{\circ} \mathrm{C}$, with the optimum being $35-37^{\circ} \mathrm{C}$, and in the $\mathrm{pH}$ range $4-9$, with the optimum range of $\mathrm{pH}$ 6.5-7.5. Salmonellae require high water activity for growth (Aw 0.94-0.99) (Graziani et al., 2017). Current testing of food and environmental samples for the presence of salmonellae can be divided into three stages: (i) detection of Salmonella spp.; (ii) identification of the species and its specific serovar designation; and (iii) subtyping of the isolate. For the detection and isolation of salmonellae, culture-based methods still dominate, with several media used in both food microbiology and for environmental sampling (Table 4). Most traditional culturebased methods for detection and isolation of salmonellae generally involve nonselective pre-enrichment, followed by a selective enrichment step, followed by plating onto selective agars, and finally biochemical and serological confirmation of presumptive colonies (Lee et al., 2015). Table 4 lists culture media and selective/differentiating compounds currently in use for food and environmental monitoring and indicates when media are recommended by standards/guidelines for environmental monitoring. 
Table 4. Culture-based media used for Salmonella detection and identification in food and environmental samples. Letters indicate corresponding standards/guidelines that recommend the media for environmental sampling (mandatory or optional).

\begin{tabular}{|c|c|}
\hline \multicolumn{2}{|r|}{ Enrichment media } \\
\hline Non Selective Enrichment Media & Selective Enrichment Media \\
\hline $\begin{array}{l}\text { Buffered peptone water (BPW) })^{\mathrm{a}, \mathrm{c}, \mathrm{d}} \\
\text { Lactose broth (LB) } \\
\text { ONE Broth-Salmonella } \\
\text { Phosphate buffered saline (PBS) } \\
\text { solutiong } \\
\text { Salmosysts broth base } \\
\text { Tryptic soy broth (TSB) } \\
\text { Modified tryptone soya broth } \\
\text { Universal pre-enrichment (PU) }^{\mathrm{a}} \\
\text { broth }^{\mathrm{f}}\end{array}$ & $\begin{array}{c}\text { Diagnostic semi-solid Salmonella agar (DiaSalm) } \\
\text { Gram-negative Hajna broth } \\
\text { Modified Semi-solid Rappaport-Vasiliadis (MSRV) medium }{ }^{\mathrm{b}, \mathrm{d}, \mathrm{e}} \\
\text { Muller-Kauffmann Tetrathionate Novobiocin (MKTTn) broth } \\
\text { Manitol selenite broth } \\
\text { Peptone-Novobiocin broth } \\
\text { Rappaport-Vassiliadis (RV) medium }{ }^{\mathrm{a}} \\
\text { Rappaport-Vassiliadis Soya Peptone (RVS) medium }{ }^{\mathrm{c}, \mathrm{d}} \\
\text { Selenite Cystine (SC) broth } \\
\text { Simple method Salmonella (SMS) agar } \\
\text { Tetrathionate (TT) broth }\end{array}$ \\
\hline & ctive/differential Plate Media \\
\hline
\end{tabular}

\section{Traditional Plate Media}

Selective/differential Plate Media

Salmonella-Shigella (SS) agar ${ }^{\mathrm{d}}$

Brilliant green (BG) agar $^{\mathrm{c}, \mathrm{d}}$

Brilliant green-phenol red-lactosesucrose (BPLA) agar ${ }^{\mathrm{a}}$

Bismuth-sulfite (BS) agar, ${ }^{\mathrm{c}, \mathrm{d}^{*}, \mathrm{f}}$

Hektoen enteric (HE) agar $^{d}$

MacConkey agar

Miller-Mallinson (MM) ${ }^{\mathrm{d}, \mathrm{f}}$

Xylose-lysine-deoxycholate (XLD)

$\operatorname{agar}^{\mathrm{a}, \mathrm{b}, \mathrm{c}, \mathrm{d}, \mathrm{e}}$

Xylose Lysin Tergitol (XLT4) agar ${ }^{\mathrm{d}}$ Deoxycholate citrate lactose agar

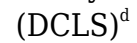

Deoxycholate citrate agar DCA

(Leifson agar) $^{\mathrm{d}}$

Mannitol lysine crystal violet

brilliant green (MLCB) $\operatorname{agar}^{\mathrm{d}}$

Selective/inhibitory Reagents

chromID ${ }^{\circledR}$ Salmonella / Salmonella Identification medium II (SMID II) ${ }^{\mathrm{d}}$ SM-ID agar/SMID2/CHROMOID2/Rambach agar ${ }^{\mathrm{a}}$ BBL CHROMagar

Salmonella SMS -agar

RAPID Salmonella plate SALSA plate

ASAP Salmonella ${ }^{\mathrm{d}}(\mathrm{C} 8)$

Harlequin Salmonella ABC/ ab-Chromogenic (ABC) medium ${ }^{\mathrm{d}}$

Oxoid Brilliance Salmonella Agar (Oxoid)/Oxoid Salmonella Chromogenic medium II ${ }^{\mathrm{d}}$ Chromogenic Salmonella esterase (CSE) ${ }^{\mathrm{d}}$

HiChrome ${ }^{\mathrm{TM}}$ Salmonella agar RaiHans

bile salts

bismuth sulfite

brilliant green

cefsulodin

cycloheximide

sodium deoxycholate

ferric ammonium citrate III

malachite green, nitrofurantoin

novobiocin, sulphacetamide

sulfadiazine

sulphamethazine

sulfapyridine

tetrathionate

tergitol

sodium thiosulphate

ferrioxamine $\mathrm{E}$

Oxyrase $^{\mathrm{TM}}$

Inhibigen $^{\mathrm{TM}}$

Biochemical/differential Tests (Salmonella Reaction, Predominant*)

${ }^{\mathrm{a} C E N / T R ~ 15215, ~} 2006$ Characterization of sludges - Detection and enumeration of Salmonella spp. in sludges, soils, soil improvers, growing media and biowastes - Parts 1-3; ' ${ }^{\text {USEPA, }} 2006$ Method 1682: Salmonella in Sewage Sludge (biosolids) by Modified Semisolid Rappaport-Vassiliadis (MSRV) Medium (EPA-821-R06-14); 'ISO 19250, 2010 Water quality -Detection of Salmonella spp.; ${ }^{\mathrm{d}}$ ISO 6579, 2017 Microbiology of the food chain - Horizontal method for the detection, enumeration and serotyping of Salmonella, Parts 1-3; ${ }^{e}$ USEPA, 2012. Method 1200: Analytical Protocol for Non-Typhoidal Salmonella in Drinking Water and Surface Water (EPA. EPA 817-R-12-004); ${ }^{\mathrm{f} U S E P A, ~ 2010 . ~ S t a n d a r d ~ A n a l y t i c a l ~ P r o t o c o l ~ f o r ~}$ Salmonella Typhi in Drinking Water (EPA/600/R-10/133) 
Culture-based methods are still the most widely used for salmonellae testing of environmental samples due to their sensitivity and selectivity. A major drawback is that 5-7 days is typically required to obtain a result, especially because multiple culture- and identification steps are required. Chromogenic and fluorogenic growth media (Table 4) for detection, enumeration, and identification directly on the isolation plate will make the test result using these selective media typically available at least 1 day earlier than conventional methods (Mooijman, 2012). These media are in general as sensitive as conventional culture media but improved in regard to readability. Attempts to shorten the total culture time for the isolation of Salmonella spp. are ongoing, often by combining culture steps. For example, in Salmosysts broth and the ONE BrothSalmonella, the pre-enrichment and the selective enrichment are combined in one culture step (Mooijman, 2012). When such enrichment is combined with a chromogenic medium (e.g., in Qxoid Salmonella Precis; Simple Method Salmonella SMS or BioRad 7 methods) presumptive Salmonella can be recognized in $42 \mathrm{~h}$ to 3 days. There is also a rapid API kit available for enterobacteriaceae differentiation (Rapid $20 \mathrm{E}$ ), which performs the biochemical testing in 4 hours compared to the typical 18-24 h (BioMérieux).

Lee et al. (2015) and Silva et al. (2018) both reviewed methods for salmonellae detection and identification for the purpose of food safety and emergency response and provide a comprehensive list of commercially-available biochemical tests for salmonella confirmation. For culture media formulation and how to interpret responses to media and tests presented in Table 4, we refer to U.S. FDA Bacteriological Analytical Manual (BAM) Chapter 5: Salmonella (Andrews et al., 2011). Mooijman et al. (2012) also present a comprehensive description about culture media used to detect salmonellae in food microbiology. Further details are found in Appendix A

\subsubsection{Molecular methods}

Salmonella can also be detected via molecular methods targeting macromolecules (e.g., DNA, RNA, proteins) specific to the pathogen. Generally, molecular methods for salmonellae can be divided into immuno-based assays and nucleic acid based-assays, although some methods, such as lateral flow assays and biosensors, are applied to a wide range of compounds (Bahadir and Sezgintürk, 2016). An enrichment step is often used to concentrate salmonellae prior to rapid molecular confirmation, e.g., using immunobased assays, which can shorten the time for analysis. Depending on the enrichment method, analysis time can be reduced by as much as 48 hours. Nucleic acid based-assays, on the other hand, are designed to serve as a means of primary detection and screening, rather than for viability confirmation. They can be used to help determine if viable but non-culturable (VBNC) cells exist but cannot be used to directly determine viability or virulence. Details are found in Appendix A

\subsubsection{Applicability for environmental sampling}

Detecting and enumerating salmonellae in environmental samples is particularly challenging, especially when seeking to differentiate strains and serovars. Most works to date apply culture with PCR or other confirmation, but there are some reports of direct analysis of environmental samples using PCR-based methods. Environmental samples are typically complex and variable matrixes are prone to interfere with analysis media. Additionally, the number of salmonellae cells in the samples may be low, whereas other environmental bacteria may be abundant. Addressing the diversity of bacteria with selective media may in turn not allow injured cells to grow. Similarly, inhibitors, such as humic acids and metals, that are co-extracted with DNA or RNA can interfere with subsequent PCR-based analyses. There are reference methods for analysis of salmonellae in a wide range of environmental samples, including: sewage sludge (USEPA, 2006; SIS-CEN 15216, 2006); wastewater (ISO, 2010), drinking water (ISO, 2010; USEPA, 2012;USEPA, 2010), surface waters (ISO, 2010; USEPA, 2012; USEPA, 2010) and soil (SIS-CEN 15216, 2006). For soil, sediments, and other environmental matrices that may not be directly covered by a specific standard, the U.S. EPA /FDA Selected Analytical Methods for Environmental Remediation and Recovery (SAM) (Campisano et al., 2017) do suggest methods for sample preparation and subsequent analysis by culture or PCR (Table 5). The latest ISO standard method for salmonella in the food chain, ISO 6579 (2017) is applicable for samples from the primary production stage such as animal feces, dust, and swabs (ISO 6579 - Part 1) and also guide on the procedure for serotyping Salmonella serovars, independent of the source from which they are isolated (ISO 6579 - Part 3) (Table 5).

Table 5. Salmonella spp. concentrations in manure samples

\begin{tabular}{|c|c|c|c|c|c|}
\hline Area & Matrices & $\begin{array}{c}\text { Salmonella Serovar or } \\
\text { Gene }\end{array}$ & $\begin{array}{l}\text { Percent Positives } \\
\text { (\# of Samples) }\end{array}$ & $\begin{array}{c}\text { Concentrations } \\
\text { CFU or GC/g } \\
\text { Average } \\
\text { (Min to Max) } \\
\end{array}$ & Reference \\
\hline Australia & $\begin{array}{l}\text { Cattle, } \\
\text { fresh }\end{array}$ & invA & $\begin{array}{c}32 \% \\
(6)\end{array}$ & $2.5 \mathrm{E}+03 \mathrm{GC}$ & $\begin{array}{l}\text { Klein et } \\
\text { al., } 2010\end{array}$ \\
\hline Ireland & $\begin{array}{l}\text { Pig, } \\
\text { infected } \\
\text { only }\end{array}$ & S. Typhimurium & (20) & $\begin{array}{c}\mathrm{NR}^{\mathrm{b}} \\
(1.0 \mathrm{E}+00 \text { to } \\
1.0 \mathrm{E}+04)\end{array}$ & $\begin{array}{l}\text { Lynch et } \\
\text { al., } 2017\end{array}$ \\
\hline
\end{tabular}




\begin{tabular}{|c|c|c|c|c|c|}
\hline Area & Matrices & $\begin{array}{c}\text { Salmonella Serovar or } \\
\text { Gene }\end{array}$ & $\begin{array}{l}\text { Percent Positives } \\
\text { (\# of Samples) }\end{array}$ & $\begin{array}{c}\text { Concentrations } \\
\text { CFU or GC/g } \\
\text { Average } \\
\text { (Min to Max) } \\
\end{array}$ & Reference \\
\hline UK & $\begin{array}{l}\text { Cattle, } \\
\text { fresh }\end{array}$ & Salmonella spp. & $\begin{array}{l}7.7 \% \\
(810)\end{array}$ & $\begin{array}{c}3.9 \mathrm{E}+04 \\
(\mathrm{NR} \text { to } 5.8 \mathrm{E}+05)\end{array}$ & $\begin{array}{l}\text { Hutchison } \\
\text { et al., } \\
2004\end{array}$ \\
\hline UK & Pig, fresh & Salmonella spp. & $\begin{array}{l}7.9 \% \\
(126)\end{array}$ & $\begin{array}{c}9.6 \mathrm{E}+03 \\
(\mathrm{NR} \text { to } 7.8 \mathrm{E}+04)\end{array}$ & $\begin{array}{l}\text { Hutchison } \\
\text { et al., } \\
2004\end{array}$ \\
\hline UK & $\begin{array}{l}\text { Poultry } \\
\text { litter, } \\
\text { fresh }\end{array}$ & Salmonella spp. & $\begin{array}{c}17.9 \% \\
(67)\end{array}$ & $\begin{array}{c}5.0 \mathrm{E}+03 \\
(\mathrm{NR} \text { to } 2.2 \\
\mathrm{E}+04)\end{array}$ & $\begin{array}{l}\text { Hutchison } \\
\text { et al., } \\
2004\end{array}$ \\
\hline UK & $\begin{array}{l}\text { Sheep, } \\
\text { fresh }\end{array}$ & Salmonella spp. & $\begin{array}{l}8.3 \% \\
(24)\end{array}$ & $\begin{array}{c}1.1 \mathrm{E}+03 \\
(\mathrm{NR} \text { to } 2.0 \mathrm{E}+03)\end{array}$ & $\begin{array}{l}\text { Hutchison } \\
\text { et al., } \\
2004\end{array}$ \\
\hline USA & $\begin{array}{l}\text { Poultry } \\
\text { litter, } \\
\text { stored } 4 \\
\text { weeks }\end{array}$ & Salmonella spp. & $\begin{array}{l}\text { NR } \\
(6)\end{array}$ & $\begin{array}{c}\mathrm{NR} \\
(2.0 \mathrm{E}+02 \text { to } \\
1.4 \mathrm{E}+05)\end{array}$ & $\begin{array}{l}\text { Hruby et } \\
\text { al., } 2018\end{array}$ \\
\hline
\end{tabular}

${ }^{\mathrm{a}}$ Concentrations as CFU (Colony Forming Units) unless noted as GC (Gene Copies); ${ }^{\mathrm{b}}$ NR: Not Reported

Sewage fractions, due to their nature or treatment (e.g. alkaline stabilization), potentially have low or high $\mathrm{pH}$ and can contain considerable amounts of ammonia, which may be toxic to the salmonella cultivation if the $\mathrm{pH}$ in the culture media is/will become alkaline during incubation. The effect on culture media from the matrix will be most crucial during the pre-enrichment step. The U.S. EPA (2006) guidelines for sewage sludge analyses suggest initial adjustment of sludge $\mathrm{pH}$ to 7.0-7.5. Different preenrichment media (LB, BPW, UP, M-9, TT and RV) applied to environmental poultry samples was found to result in different $\mathrm{pH}$, with $\mathrm{LB}$ having the lowest $\mathrm{pH}$ of 4.7 , whereas in UP, M-9, and BPW, the lowest pH was 6.1-6.4 (Cox et al., 2018). U.S. EPA reference methods for drinking and surface waters suggest dilution with double strength preenrichment solution when pre-enriching water samples to account for dilution effects. Filtration can also be used to overcome influences from complex sample matrixes, which could interfere with the media and is by ISO 15215:1 (2006) recommended for resuscitation of sub-lethally stressed bacteria for sludge samples with TS up to $20 \%$. The standard/technical report by the European committee for standardization (CEN) for characterization of sludges, soils, soil amendments, growth media and biowastes recommend that a novobiocin-supplemented peptone water is used as a primary medium to suppress competing microflora. Similarly, to the ISO19250 (2010) water standard, direct inoculation in selective media is recommended when waste water is analyzed. Among nonselective enrichment media in the standards/methods listed in Table 5 are buffered peptone water (BPW) and Tryptic soy broth (TSB) for primary enrichment of salmonellae in general and universal pre-enrichment broth (UP) for $S$. Typhi (Table 4).
For the nucleic acid based methods, DNA can be extracted for downstream PCR and qPCR to determine the presence/ absence and quantity of the target gene. Method development for the type of environmental sample of interest is required to ensure that an appropriate amount of sample is collected. Significant dilution may also be required to reduce the effects of PCR inhibitors. Messenger-RNA (mRNA) using reverse transcription PCR (RT-PCR) can be used to better assess the viable population due to short half-life of mRNA and detection of mRNA from housekeeping genes are indicative for active transcription. For culture-based methods, elevated nutrients and temperature (sometimes suggested stepwise $10^{\circ} \mathrm{C}$ at a time) are applied to rescuing VBNC state and generally stressed cells. Baloda et al. (2001) did find the conventional culture method (pre-culture in enriched, buffered peptone water followed by the use of selective media) to be more reliable and sensitive method for complex environmental samples compared to molecular methods such as Salmonella-specific PCR. For plate culturing, the cells can be subjected to less stress by overlaying selective agar with a nonselective agar, e.g. overlaying XLD with TSA. Standard methods are still being established in nucleic methods and genes used for detection in environmental samples vary (Table 5).

Karkey et al. has shown success in extracting from utilizing the Metagenomic DNA Isolation Kit for Water and diluting extracted DNA 1:20 (Karkey et al., 2016). This, in conjunction with enrichment plating successfully identified Salmonella in well waters.

\subsection{Occurrence in the Environment}




\subsubsection{Animal manure}

Agricultural livestock are widely recognized as carriers of Salmonella spp. (Jacobsen and Bech, 2012) and salmonellae have been isolated from numerous species of farm animals, including poultry, cattle, pigs, and sheep (Abulreesh, 2012). It is predominantly serovars of $S$. enterica subspecies enterica that infect warm blooded animals (including humans). The non-enterica subspecies of $S$. enterica are considered to be related to cold-blooded animals and human infections more common in immunocompromised individuals (Lamas et al., 2018). Salmonellae appearing as commensals in farm animals, but not associated with infection in humans in the same region, indicates that not all salmonellaes are of clinical interest (Lamas et al., 2018). Whereas some salmonellae infect mainly one or few species, some are highly zoonotic and infect humans as well as animal hosts. For some serovars, the animals act as asymptomatic carriers whereas the salmonella causes illness in human. Table 6 includes, for comparison with excreta/sewage fractions, some references on concentrations of salmonellae in animal manure.

Table 6. Salmonella spp. in urine, black water, latrine and septic tank sludge

\begin{tabular}{|c|c|c|c|c|c|}
\hline Area & Matrices & $\begin{array}{c}\text { Salmonella Serovar or } \\
\text { Gene }\end{array}$ & $\begin{array}{l}\text { Percent Positives } \\
\text { (\# of Samples) }\end{array}$ & $\begin{array}{c}\text { Concentrations }^{\mathrm{a}} \\
\text { CFU or MPN/ ml or } \mathrm{g} \\
\text { Average } \\
\text { (Min to Max) } \\
\end{array}$ & Reference \\
\hline Australia & $\begin{array}{l}\text { Urine, } \\
\text { human, } \\
\text { individual } \\
\text { samples }\end{array}$ & Non typhoidal Salmonella & $\begin{array}{l}N^{b} \\
(23)\end{array}$ & $\begin{array}{l}>1.0 \mathrm{E}+05 \\
\quad / \mathrm{ml}\end{array}$ & $\begin{array}{l}\text { Paterson } \\
\text { et al., } \\
1997\end{array}$ \\
\hline Malawi & $\begin{array}{l}\text { Latrine } \\
\text { sludge, } \\
\text { Fossa } \\
\text { alternas }\end{array}$ & Salmonella spp. & $\begin{array}{l}\text { NR } \\
(11)\end{array}$ & $\begin{array}{c}3.46 \mathrm{E}+02 \\
(<1 \text { to1.2 } \mathrm{E}+03) \\
/ \mathrm{g}\end{array}$ & $\begin{array}{l}\text { Kumwenda } \\
\text { et al., } \\
2017\end{array}$ \\
\hline Malawi & $\begin{array}{l}\text { Latrine } \\
\text { sludge, } \\
\text { Urine dry } \\
\text { diverting } \\
\text { toilets }\end{array}$ & Salmonella spp. & $\begin{array}{l}\text { NR } \\
(13)\end{array}$ & $\begin{array}{c}5.09 \mathrm{E}+02 \\
(<1 \text { to } 3.2 \mathrm{E}+03) \\
/ \mathrm{g}\end{array}$ & $\begin{array}{l}\text { Kumwenda } \\
\text { et al., } \\
2017\end{array}$ \\
\hline $\begin{array}{l}\text { South } \\
\text { Africa }\end{array}$ & $\begin{array}{l}\text { Latrine } \\
\text { sludge, } \\
\text { Ecosan } \\
\text { toilets }\end{array}$ & Salmonella spp. & $\begin{array}{l}\mathrm{NR} \\
(\mathrm{NR})\end{array}$ & $\begin{array}{c}2.2 \mathrm{E}+05 \\
(\mathrm{NR}) \\
\text { /g dry matter }\end{array}$ & $\begin{array}{l}\text { Jimenez et } \\
\text { al., } 2006\end{array}$ \\
\hline Sweden & $\begin{array}{l}\text { Black } \\
\text { water, } \\
100 \text { pec }\end{array}$ & Stanley; Bareilly & $\begin{array}{l}\text { NR } \\
(\mathrm{NR})\end{array}$ & $\begin{array}{c}\text { NR } \\
(0.2 \mathrm{E}+01 \text { to } \\
0.35 \mathrm{E}+01) / \mathrm{mL}\end{array}$ & $\begin{array}{l}\text { Nordin } \\
\text { and } \\
\text { Vinneras, } \\
2015\end{array}$ \\
\hline USA & $\begin{array}{c}\text { Urine, } \\
\text { human, } \\
\text { individual } \\
\text { samples, } \\
\text { all } \\
\text { infected }\end{array}$ & $\begin{array}{c}\text { Montevideo; Oranienberg; Senftenberg; } \\
\text { Meleagridis }\end{array}$ & $\begin{array}{l}\text { NR } \\
(65)\end{array}$ & $\begin{array}{c}\mathrm{NR} \\
(>1.0 \mathrm{E}+05-1.0 \mathrm{E}+04) \\
/ \mathrm{mL}\end{array}$ & $\begin{array}{l}\text { Abbot et } \\
\text { al., } 1999\end{array}$ \\
\hline Vietnam & $\begin{array}{l}\text { Septic } \\
\text { tank } \\
\text { sludge }\end{array}$ & Salmonella spp. & $\begin{array}{l}60 \% \\
(20)\end{array}$ & $\begin{array}{c}5.79 \mathrm{E}+02 \\
(9.0 \mathrm{E}+01 \text { to } 1.9 \mathrm{E}+03) \\
\mathrm{MPN} / \mathrm{g} \text { dry matter }\end{array}$ & $\begin{array}{l}\text { Yen-phi et } \\
\text { al., } 2010\end{array}$ \\
\hline
\end{tabular}

${ }^{\mathrm{a}}$ Concentrations as CFU (Colony Forming Units) unless noted as MPN (Most Probable Number); ${ }^{\mathrm{b}}$ NR: Not Reported; ${ }^{\mathrm{c}} \mathrm{PE}$ : Person Equivalent

\subsubsection{Human excreta}

Most salmonellae infecting humans are excreted via the faeces, but $S$. Typhi and Paratyphi are, during the phase of typhoid and paratyphoid fevers, excreted in the urine
(Schönning and Stenström, 2004). However, NTS cases of urinary tract infection has been recorded with concentrations of $>100,000$ colony forming units $\mathrm{mL}-1$ urine (Allerberger et al., 1992; Abbott et al., 1999). Even if salmonellosis is among the common causes of enteritis in 
humans, studies report mainly prevalence and duration and not faecal excretion rates. There are a few publications reporting presence of salmonellae in source-separating sanitation systems. Concentrations of culturable salmonella in a black water system in Sweden (Nordin and Vinneras,
2015) was rather low compared to latrine sludge samples in South Africa (Jimenez et al., 2007; Jimenez et al., 2006) and Malawi (Kumwenda et al., 2017), despite the fact that in the latter studies samples were taken after a 12 months waiting period (Table 7).

Table 7. Salmonella spp. in raw and treated sewage

\begin{tabular}{|c|c|c|c|c|c|}
\hline Area & Matrices, Level of Treatment & $\begin{array}{c}\text { Salmonella Serovar } \\
\text { or } \\
\text { Gene }\end{array}$ & $\begin{array}{l}\text { Percent } \\
\text { Positives } \\
\text { (\# of } \\
\text { Samples) }\end{array}$ & $\begin{array}{c}\text { Concentrations } \\
\text { CFU or MPN / 100ml } \\
\text { Average } \\
\text { (Min to Max) } \\
\end{array}$ & Reference \\
\hline \multicolumn{6}{|c|}{ Raw Wastewater } \\
\hline Poland & $\begin{array}{c}1 \text { facility }^{\mathrm{b}}, 315,000 \mathrm{PE}^{\mathrm{c}} \text {, sampled } \\
\text { over } 1 \mathrm{yr}\end{array}$ & S. Typhimurium & $100 \%(12)$ & $\begin{array}{c}\text { NR } \\
(2.5 \mathrm{E}+05 \text { to } 1.43 \mathrm{E}+06)\end{array}$ & $\begin{array}{l}\text { Kacprzak } \\
\text { et al., } \\
2015\end{array}$ \\
\hline Poland & $\begin{array}{c}1 \text { facility }^{\mathrm{b}}, 315,000 \mathrm{PE} \text {, sampled over } \\
1 \mathrm{yr}\end{array}$ & bipA & $\begin{array}{l}100 \% \\
(12)\end{array}$ & $\begin{array}{c}(1.1 \mathrm{E}+06 \text { to } 5.81 \mathrm{E}+07 \\
\mathrm{GC})\end{array}$ & $\begin{array}{l}\text { Kacprzak } \\
\text { et al., } \\
2015\end{array}$ \\
\hline Spain & 1 facility, sampled over 7 months & Salmonella spp. & $\begin{array}{l}\text { NR } \\
(21)\end{array}$ & $\begin{array}{l}2.67 \mathrm{E}+02 \mathrm{MPN} \\
(\mathrm{NR})\end{array}$ & $\begin{array}{l}\text { Howard et } \\
\text { al., } 2004\end{array}$ \\
\hline Taiwan & 9 hospital facilities $^{\mathrm{b}}$ & Salmonella spp. & $\begin{array}{l}33.3 \% \\
(27)\end{array}$ & $\begin{array}{c}\mathrm{NR} \\
(1.0 \mathrm{E}+02 \text { to } 1.0 \mathrm{E}+05)\end{array}$ & $\begin{array}{l}\text { Tsai et al., } \\
1998\end{array}$ \\
\hline Zimbabwe & 1 facility, 100,000 PE & Salmonella spp. & $65 \%(\mathrm{NR})$ & $\begin{array}{l}1.0 \mathrm{E}+08 \\
(\mathrm{NR})\end{array}$ & $\begin{array}{l}\text { Gopo and } \\
\text { Chingobe, } \\
1995\end{array}$ \\
\hline \multicolumn{6}{|c|}{ Treated Wastewater Effluent } \\
\hline Poland & $\begin{array}{l}1 \text { facility, 315,000 PE, activated } \\
\text { sludge sampled over } 1 \text { year }\end{array}$ & S. Typhimurium & $\begin{array}{l}50 \% \\
(12)\end{array}$ & $\begin{array}{c}\mathrm{NR} \\
(2.0 \mathrm{E}+04 \text { to1.47E+05) }\end{array}$ & $\begin{array}{l}\text { Kacprzak } \\
\text { et al., } \\
2015\end{array}$ \\
\hline Poland & $\begin{array}{l}1 \text { facility, 315,000 PE, activated } \\
\text { sludge sampled over } 1 \text { year }\end{array}$ & bipA & $\begin{array}{l}75 \% \\
(12)\end{array}$ & $\begin{array}{c}\mathrm{NR} \\
\text { (0 to } 2.8+06 \mathrm{GC})\end{array}$ & $\begin{array}{l}\text { Kacprzak } \\
\text { et al., } \\
2015\end{array}$ \\
\hline $\begin{array}{l}\text { South } \\
\text { Africa }\end{array}$ & $\begin{array}{c}2 \text { facilities, activated sludge } \\
\text { process, chlorination, sampled over } \\
1 \text { year }\end{array}$ & Salmonella spp. & $\begin{array}{l}\text { NR } \\
(>24)\end{array}$ & $\begin{array}{c}\mathrm{NR} \\
(1.0 \mathrm{E}+03 \text { to } 2.0 \mathrm{E}+05)\end{array}$ & $\begin{array}{l}\text { Odjadjare } \\
\text { and } \\
\text { Olaniran, } \\
2015\end{array}$ \\
\hline Spain & $\begin{array}{l}1 \text { facility, activated sludge process, } \\
\text { sampled over } 7 \text { months. }\end{array}$ & Salmonella spp. & $\begin{array}{l}\text { NR } \\
(21)\end{array}$ & $\begin{array}{l}\text { 4.5E+01 MPN } \\
\quad(\mathrm{NR})\end{array}$ & $\begin{array}{l}\text { Howard et } \\
\text { al., } 2004\end{array}$ \\
\hline Zimbabwe & $\begin{array}{c}1 \text { facility, modified activated sludge } \\
\text { process }\end{array}$ & Salmonella spp. & $\begin{array}{l}52 \% \\
(\mathrm{NR})\end{array}$ & $<1 \mathrm{E}+02$ & $\begin{array}{l}\text { Gopo and } \\
\text { Chingobe, } \\
1995\end{array}$ \\
\hline
\end{tabular}

${ }^{\mathrm{a}}$ Concentrations as CFU (Colony Forming Units), unless noted as MPN (Most Probable Number); ${ }^{\text {b} W a s t e w a t e r ~}$ treatment facility; ${ }^{\mathrm{c}} \mathrm{PE}$ : Person Equivalent

\subsubsection{Sewage/ wastewater and wastewater effluent}

Systems collecting mixed waste water are generally larger than source-separating systems and the material is likely to contain salmonellae. In Sweden, it has been suggested that with more than 5,000 people connected to a sewage system, Salmonella can be expected in the waste water (Albihn and Stenstrom, 1998). However, even though the reported human salmonella prevalence /incidence in Sweden is rather low, salmonella has been detected in black water from rather small systems (<100 PE) (Nordin and Vinneras, 2015; Nordin et al., 2018).

When Salmonella concentrations have been studied at different points in wastewater treatment systems, in general a decrease in concentration is observed as treatment progresses (Howard et al., 2004). However, the reduction is typically not sufficient to eliminate salmonellae, which are frequently found in treated effluent, even after disinfecting treatment including chlorination and 
UV-treatment (Kinde et al., 1997; Santiago et al., 2018). Due to variation over locations, the concentration in treated effluent is for some studies higher than in the incoming wastewater in other locations/studies.

2.2.4 Biosolids/Sludge
Of the sewage fractions /products sewage sludge are most thoroughly analyzed with respect to salmonella. Salmonella spp. are frequently found in sewage sludge where concentrations as high as $10^{7} \mathrm{cfu}$ per $\mathrm{ml}$ has been reported for raw sludge (Parmar et al., 2001; Sahlstrom et al., 2004)(Table 8). Post storage of sewage sludge repopulation may occur and has been related to changes in water content, e.g. rain fall (Zaleski et al., 2005).

Table 8. Salmonella spp. in sewage sludge

\begin{tabular}{|c|c|c|c|c|}
\hline Area & Matrices, Sludge Treatment & $\begin{array}{l}\text { Percent Positives } \\
\text { (\# of Samples) }\end{array}$ & $\begin{array}{l}\text { Concentrations } \\
\text { CFU or MPN/ g or } \mathrm{ml}^{\mathrm{a}} \\
\text { Average (Min to Max) }\end{array}$ & Reference \\
\hline Brazil & $\begin{array}{c}5 \text { facilities, sampled over } 1 \\
\text { year, MAD followed by } \\
\text { dewatering and liming ( } 3 \text { of } 5 \\
\text { facilities) }\end{array}$ & $\begin{array}{l}39 \% \\
(54)^{b}\end{array}$ & $\begin{array}{c}\mathrm{NR} \\
(0.43 \text { to } 1.22 \mathrm{E}+01) / \mathrm{g} \\
\text { dry matter }\end{array}$ & $\begin{array}{l}\text { Krzyzanowski } \\
\text { et al., } 2014\end{array}$ \\
\hline Canada & 1 facility, MAD & $\begin{array}{l}\mathrm{NR} \\
(\mathrm{NR})\end{array}$ & $\begin{array}{c}1.5 \mathrm{E}+07 \mathrm{CFU} / \mathrm{ml} \\
(\mathrm{NR})\end{array}$ & $\begin{array}{l}\text { Parmar et al., } \\
2001\end{array}$ \\
\hline France & 1 facility, raw sludge & $\begin{array}{l}100 \% \\
(3)\end{array}$ & $\begin{array}{c}\mathrm{NR} \\
(1.2 \text { to } 3.2) / \mathrm{g} \text { dry } \\
\text { matter }\end{array}$ & $\begin{array}{l}\text { Pourcher et } \\
\text { al., } 2005\end{array}$ \\
\hline Mexico & $\begin{array}{l}1 \text { facility, } 35 \mathrm{~L} / \mathrm{s} \text {, raw sludge, } \\
\text { sampled over } 8 \text { months }\end{array}$ & $\begin{array}{l}100 \% \\
(32)^{d}\end{array}$ & $\begin{array}{c}\mathrm{NR} \\
(9.5 \mathrm{E}+06 \text { to } 1.4 \mathrm{E}+08) / \\
\text { g dry matter }\end{array}$ & $\begin{array}{l}\text { Jiminez et al., } \\
2002\end{array}$ \\
\hline Taiwan & $\begin{array}{l}9 \text { hospital facilities, various } \\
\text { sludge treatments }\end{array}$ & $\begin{array}{l}37 \% \\
(27)\end{array}$ & $\begin{array}{c}\mathrm{NR} \\
(<1 \text { to } 9.2 \mathrm{E}+04) \mathrm{CFU} / \mathrm{g} \\
\text { total solids }\end{array}$ & $\begin{array}{l}\text { Tsai et al., } \\
1998\end{array}$ \\
\hline USA & $\begin{array}{c}2 \text { facilities, MAD or aerobic } \\
\text { digestion followed by } \\
\text { drying for } 23 \text { to } 30 \text { weeks }\end{array}$ & $\begin{array}{l}\text { NR } \\
(\mathrm{NR})\end{array}$ & $\begin{array}{c}\mathrm{NR} \\
(1.0 \mathrm{E}+01 \text { to } 1.0 \mathrm{E}+02) \\
\mathrm{CFU} / \mathrm{g} \\
\text { (growth to }>1.0 \mathrm{E}+05 \\
\text { after rain) }\end{array}$ & $\begin{array}{l}\text { Zaleski et al., } \\
\quad 2005\end{array}$ \\
\hline USA & 1 facility, raw sludge & $\begin{array}{c}100 \% \\
(14)\end{array}$ & $\begin{array}{c}1.14 \mathrm{E}+03 \\
(1.0 \mathrm{E}+02 \text { to } 7 \mathrm{E}+04) / \mathrm{g}\end{array}$ & $\begin{array}{l}\text { Gerba et al., } \\
2008\end{array}$ \\
\hline USA & 1 facility, MAD & $\begin{array}{c}100 \% \\
(14)\end{array}$ & $\begin{array}{c}1.05 \mathrm{E}+02 \\
(1.0 \mathrm{E}+00 \text { to } 4.8 \mathrm{E}+02) / \\
g\end{array}$ & $\begin{array}{l}\text { Gerba et al., } \\
2008\end{array}$ \\
\hline USA & $\begin{array}{l}4 \text { facilities, MAD, } 3 \text { sampling } \\
\text { campains over } 10 \text { months }\end{array}$ & $\begin{array}{l}33 \% \\
(6)^{\mathrm{e}}\end{array}$ & $\begin{array}{c}\mathrm{NR} \\
(1.2 \mathrm{E}-01 \text { to } 2.4 \mathrm{E}-01 / \mathrm{g})\end{array}$ & $\begin{array}{l}\text { Wong et al., } \\
2010\end{array}$ \\
\hline USA & 1 facility, raw sludge & $\begin{array}{l}100 \% \\
(1)\end{array}$ & $\begin{array}{c}\mathrm{NR} \\
2.44 \mathrm{E}+02 / \mathrm{g}\end{array}$ & $\begin{array}{l}\text { Wong et al., } \\
2010\end{array}$ \\
\hline USA & $\begin{array}{c}6 \text { facilities, raw sludge from } \\
\text { setteling }\end{array}$ & $\begin{array}{l}100 \% \\
(\mathrm{NR})\end{array}$ & $\begin{array}{c}6.3 \mathrm{E}+02 \\
(2.17 \mathrm{E}+02 \text { to } 1.0 \mathrm{E}+03) \\
\text { g dry matter }\end{array}$ & $\begin{array}{l}\text { Dahab and } \\
\text { Surampalli, } \\
2002\end{array}$ \\
\hline USA & $\begin{array}{l}3 \text { facilities, raw sludge from } \\
\text { activated sludge process }\end{array}$ & $\begin{array}{c}100 \% \\
(\mathrm{NR})\end{array}$ & $\begin{array}{c}6.0 \mathrm{E}+02 \\
(4.0 \mathrm{E}+02 \text { to } 7.5 \mathrm{E}+02) / \\
\text { g dry matter }\end{array}$ & $\begin{array}{l}\text { Dahab and } \\
\text { Surampalli, } \\
\quad 2002\end{array}$ \\
\hline USA & 6 facilities, MAD & $\begin{array}{c}100 \% \\
(\mathrm{NR})\end{array}$ & $\begin{array}{c}(1.00 \mathrm{E}+00 \text { to } \\
5.20 \mathrm{E}+01) / g \text { dry } \\
\text { matter }\end{array}$ & $\begin{array}{l}\text { Dahab and } \\
\text { Surampalli, } \\
2002\end{array}$ \\
\hline
\end{tabular}

${ }^{\mathrm{a} C}$ Concentration given as MPN (Most Probable Number) unless noted as CFU (Colony Forming Unit); ${ }^{\mathrm{b}}$ Wastewater treatment facility; 'Serotypes identified: Infantis; Agona; Anatum; Corvalis ; Mbandaka; Typhimurium ; München; Salamae; Give; Javiana ; Minnesota; Molade; Newport; Ohio; Oranienburg; Ouakan; 'GC: Gene Copy; ${ }^{\mathrm{d}}$ Serotype identified S. Typhi; érotype identified $S$. Enterica 


\subsubsection{Waters}

Salmonellosis in general is considered to be a foodborne disease, mainly infecting through fresh produce, although the actual source of the salmonellae may be contaminated water. Water contaminated with human feces is one of the main transmission routes. Even if most serovars are considered to be foodborne, $S$. Typhi and $S$. Paratyphi are considered to be waterborne. Salmonellae has been detected in different countries and in a diverse range of water sources, ranging from pristine (e.g. Patchanee et al., 2010; Till et al., 2008)) and low impacted water (e.g. Patchanee et al., 2010; Jokinen et al., 2010; Meinersmann et al., 2008) to heavily impacted water sources (e.g.Jyoti et al., 2010) (Table 8). Salmonella contamination occurring in surface water used for recreational purposes (Till et al., 2008); as a source of drinking water (Till et al., 2008); and for irrigation(Gannon et al., 2004). Increasing evidence indicates that irrigation water is a key source (or a vehicle) for transmission of Salmonella (Liu et al., 2018).

Table 9. Salmonella spp. in environmental samples, soil, and water fractions

\begin{tabular}{|c|c|c|c|c|}
\hline Area & Matricies & $\begin{array}{l}\text { Percent Positives } \\
\text { (\# of Samples) }\end{array}$ & Concentrations CFU or GC/ $100 \mathrm{~mL}^{\mathrm{a}}$ & Reference \\
\hline Australia & Rain Water & (6) & $\begin{array}{l}1 \text { to } 3.8 \mathrm{E}+01 \mathrm{GC}^{\mathrm{a}} \\
\quad \text { (invA gene) }\end{array}$ & $\begin{array}{c}\text { Ahmed et al., } \\
2010\end{array}$ \\
\hline Bangladesh & Soil & $\mathrm{NR}^{\mathrm{b}}$ & $1.0 \mathrm{E}+02$ to $5.0 \mathrm{E}+02$ & $\begin{array}{l}\text { Alam and } \\
\text { Mohammad, } \\
2012\end{array}$ \\
\hline India & River water & $\begin{array}{c}87 \% \\
(8)\end{array}$ & $1.0 \mathrm{E}+04$ to $1.0 \mathrm{E}+06$ & $\begin{array}{l}\text { Jyoti et al., } \\
2011\end{array}$ \\
\hline Indiac & River Water & (18) & $\begin{array}{c}2.32 \mathrm{E}+02 \text { to } 5.89 \mathrm{E}+02 \mathrm{GC} \\
\quad(\text { staG gene) }\end{array}$ & $\begin{array}{l}\text { Rani et al., } \\
\quad 2014\end{array}$ \\
\hline Indiac & $\begin{array}{l}\text { River Water } \\
\text { Sediments }\end{array}$ & (18) & $\begin{array}{c}2.8 \text { to } \\
6.6 \mathrm{GC} / \mathrm{g}- \\
\text { (staG gene) }\end{array}$ & $\begin{array}{l}\text { Rani et al., } \\
2014\end{array}$ \\
\hline $\begin{array}{l}\text { Saudi } \\
\text { Arabia }\end{array}$ & $\begin{array}{c}\text { Soil } \\
\text { recreational } \\
\text { and } \\
\text { agricultural } \\
\text { areas }\end{array}$ & $\begin{array}{l}15.5 \% \\
(220)\end{array}$ & NR & $\begin{array}{c}\text { Abdel-Monem } \\
\text { and Dowidar, } \\
1990\end{array}$ \\
\hline $\begin{array}{l}\text { Saudi } \\
\text { Arabia }\end{array}$ & $\begin{array}{l}\text { Poultry } \\
\text { manure }\end{array}$ & NR & $37 / g$ & $\begin{array}{l}\text { Hruby et al., } \\
2018\end{array}$ \\
\hline $\begin{array}{l}\text { South } \\
\text { Africa }\end{array}$ & River water & $\begin{array}{l}\text { Upstream sewage } \\
\text { plant, sewage } \\
\text { contaminated }\end{array}$ & $1.0 \mathrm{E}+02$ to $3.5 \mathrm{E}+02$ & $\begin{array}{l}\text { Odjadjare and } \\
\text { Olaniran, } \\
2015\end{array}$ \\
\hline USA & $\begin{array}{l}\text { Lake and } \\
\text { river water }\end{array}$ & $\begin{array}{l}42 \% \\
(19)\end{array}$ & $\begin{array}{l}0.2 \text { to } \\
1.7 \mathrm{MPN}^{\mathrm{d}}\end{array}$ & $\begin{array}{l}\text { Byappanahalli } \\
\text { et al., } 2009\end{array}$ \\
\hline USA & $\begin{array}{l}\text { Pond water } \\
\text { in a water } \\
\text { shed }\end{array}$ & NR & $\begin{array}{c}0.01 \text { to } \\
0.34 \mathrm{MPN}\end{array}$ & $\begin{array}{l}\text { Jenkins et al., } \\
2008\end{array}$ \\
\hline
\end{tabular}

${ }^{\mathrm{a}} \mathrm{CFU}$ (Colony Forming Units) and GC (Gene Copies) per $100 \mathrm{ml}$ unless otherwise noted; ${ }^{\mathrm{b}}$ NR: Not Reported; ${ }^{\mathrm{c}} \mathrm{S}$. Typhi Salmonella serovar; ${ }^{\mathrm{d}} \mathrm{MPN}$ : Most Probable Number

Salmonellae frequently occur in sewage-impacted fresh and marine water environments and their detection in the water environment have been correlated with proximity to the sewage discharge area (Jacobsen and Bech, 2012; Alonso et al., 1992; Baudart et al., 2000). They have also been linked to the intensity of rainfall, suggesting importance of transport of salmonellae by overland flow and animal rearing (Phan et al., 2003). However, other studies have found as many salmonellae positive samples upstream as downstream of sewage effluent discharge (Gopo and Chingobe, 1995) and sometimes even higher concentrations upstream (Odjadjare and Olaniran, 2015). Studies have shown that salmonellae are able to colonialize the non-host environment by forming stable, dividing populations and that a stable aquatic presence not solely be the consequence of continuous bulk transfer from human and animal sources. 


\subsubsection{Soil}

Salmonella has been detected frequently in soils from both agricultural and recreational areas (Abdel-Monem and Dowidar, 1990; Thomason et al., 1975a; Thomason et al., 1975b)(Table 8). Salmonella survives for long periods and has also been found colonizing soil related to environmental and ecological niches as plant tissue and soil flagellates (Xuan Thanh et al., 2012). The presence of salmonellae in agricultural soils has been linked to use of irrigation water and organic fertilizers, such as sewage sludge and manure. It has also been shown that salmonellae can come from other sources besides irrigation or manure-derived fertilisers, such as wild birds. The same has been found in recreational land and in school yards where the salmonellae occurrence has been linked to the presence of wild animals (Phan et al., 2003; Haddock and Nocon, 1993; Haddock and Nocon, 1986).

\subsection{Persistence}

Compared to other bacteria, Salmonella spp. have high survival rates in aquatic environments and have been shown to have better survival strategies than E. coli in the natural environment (Winfield and Groisman, 2003).

The long persistence of Salmonella clones on farm premises (Baloda et al., 2001; Sandvang et al., 2000; Twiddy et al., 1988) indicates that the treatment of manures as well as other measures to prevent environmental contamination are necessary.

There is evidence to indicate that the survival of Salmonella spp. in organic-containing substrates, e.g. faecal sludge and manure, is lower than that in buffer solution. For example, Olsen and Larsen (1987) found 10-25\% lower survival of Salmonella spp. in manure than for the same bacteria in the treatment capsuled in nylon bags added where the bacteria were kept in tryptic soy broth. However, Smith et al. (2005) observed the opposite, i.e. higher survival of Salmonella spp. in TSB than in sewage sludge at $55^{\circ} \mathrm{C}$, although some chemical substances, not investigated, could have affected the survival in the sludge.

The survival of Salmonella spp. in soil is determined by various factors, including temperature, moisture, soil type, presence of plants, exposure to sun (UV) light, protozoan predation (Garcia et al., 2010), and competing microbial community members (Schierstaedt et al., 2016; Abd-Elall and Maysa, 2015). Salmonellae have been reported to survive for more than one year (Davies and Wray, 1996), with longer survival in clay soil than sandy soils (Nicholson et al., 2005) and in soils amended with organic material (Ellis et al., 2018; Paluszak et al., 2003). Salmonellae survival in soil has been correlated to soil moisture and temperature (Garcia et al., 2010; Pepper et al., 1993; Danyluk et al., 2008). However, Ongeng et al. (2015) reviewed survival of Salmonella in manure-amended soils and inconsistencies among survival times in soil, likely reflecting environmental variability of differences in methodology. Further, they noted that persistence under field conditions are inconsistent compared to controlled environmental studies, where often one factor is singled out. It was also highlighted that, for many survival studies, populations potentially removed from soil by leaching are often not accounted for (Ongeng et al., 2015). Many studies from the field do not quantify the concentrations of salmonellae in soil, but merely detect its continued detection. Persistence of Escherichia coli and Salmonella spp. in surface soil following application of liquid hog manure for production of pickling cucumbers has also been documented (Cote and Quessy, 2005). Salmonella was also still present in one plot at the beginning of harvest time in the last year of the experiment, with a maximal persistence of 54 days in loamy sand and 27 days in sandy loam.

\subsection{Reductions by Sanitation Measures}

\subsection{Biological Treatment}

\subsubsection{Latrines, septic tanks and wastewater treatment}

Removal may be similar to E.coli, please see Pathogenic members of Escherichia coli \& Shigella spp. Shigellosis for further information.

\subsubsection{Excreta, biosolids and manure}

\subsubsection{Anaerobic digestion}

Thermophilic anaerobic digestion at temperatures of $53^{\circ} \mathrm{C}$ and above brings about a rapid reduction in Salmonella spp., with D-values below one hour in all cases (Figure 1). During mesophilic $\left(30-45^{\circ} \mathrm{C}\right)$ treatment, the reduction is very inconsistent and ranges from no reduction during 20 days of treatment (Smith et al., 2005; Shih, 1987), to a D-value of 1.7 days (Olsen and Larsen, 1987). Olsen and Larsen (1987) also found a great difference in treatment efficiency between 30 and $35^{\circ} \mathrm{C}$. At colder temperatures $\left(<30^{\circ} \mathrm{C}\right)$, rapid inactivation is reported in some studies (Cote et al., 2006), while others report limited to no reduction during the treatment (Figure 1). Compared with Salmonella spp., E. coli cells are more sensitive to the environment and are thereby inactivated faster during anaerobic digestion than cells of Salmonella spp. (Figure 1). 


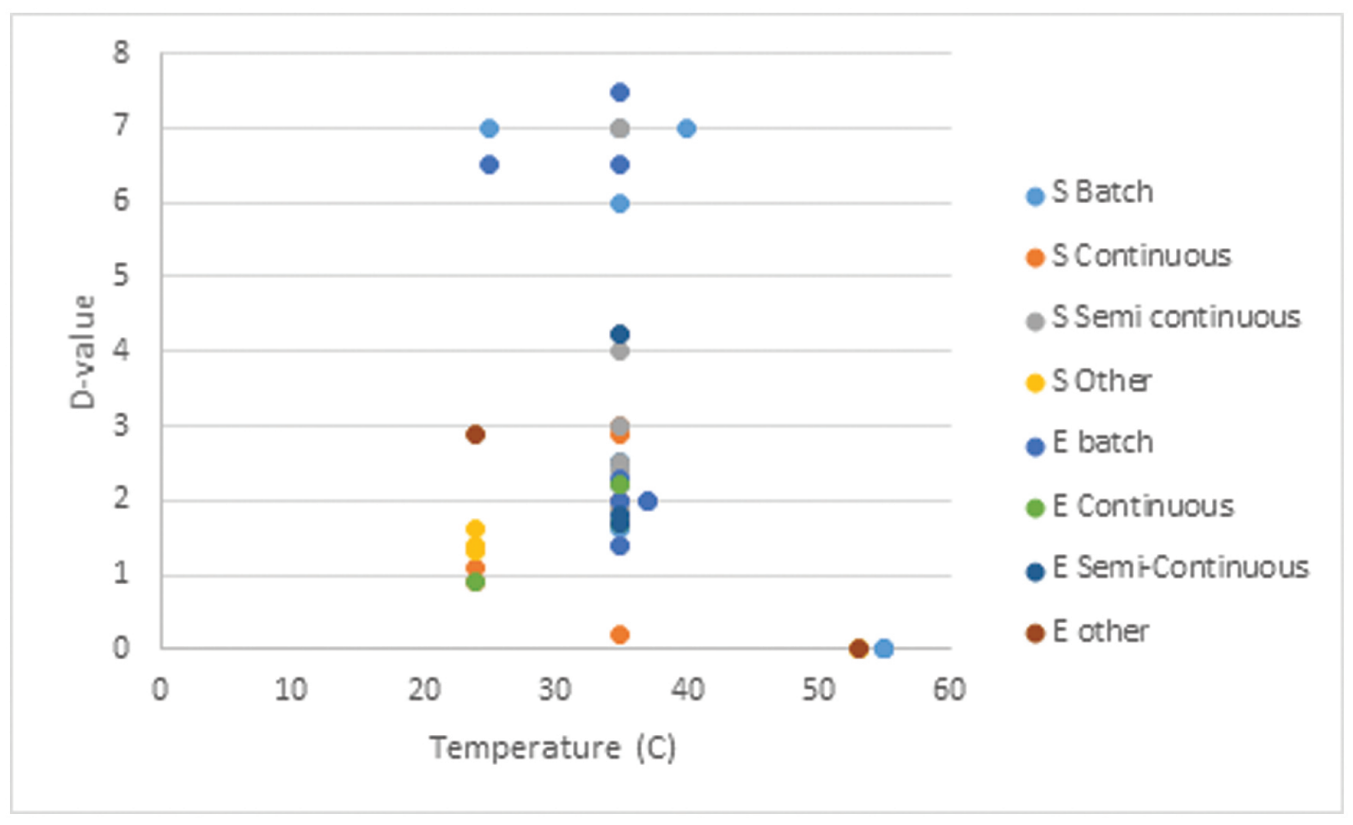

Figure 1. Decimal reduction (D) values (days) for $90 \%$ inactivation of Salmonella spp. (S) and Escherichia coli (E) during anaerobic digestion at temperatures from 24 to $55^{\circ} \mathrm{C}$ in batch, semi-continuous, semi-continuous or other reactors (average values from different treatment methods) (Abd-Elall and Maysa, 2015; Davies and Wray, 1996; Loewen and HenggeAronis, 1994; Spector and Kenyon, 2012; Lianou and Koutsoumanis, 2013; Pin et al., 2012; Erickson et al., 2014; Vinneras, 2013; Scaglia et al., 2014; Sidhu et al., 2001; Elving et al., 2014; Shih, 1987; Cote, Masse and Quessy, 2006; Termorshuizen et al., 2003).

Increased retention time within treatment increases the reduction effect. For example, Yen-Phi et al., (2009) showed that increasing the retention time from 3 to 30 days increased the reduction in $S$. Senftenberg $775 \mathrm{~W}$ by $1 \log _{10}$. However, in mixed systems it is important to have a minimal retention time within the process, i.e. the shortest time from a material entering the reactor until it exits or, in fully mixed fed batch reactor systems, the time between loadings. To ensure pathogen inactivation within an anaerobic system at mesophilic or psychrophilic temperature, the treatment needs to be validated regarding the effect upon salmonellae, while thermophilic treatment requires time and temperature validation to confirm salmonella inactivation.

\subsubsection{Fly larvae/vermicomposting}

Fly larvae composting is rapidly gaining popularity as an alternative treatment method within faecal sludge management (Lalander et al., 2019; Lalander et al., 2013; Mutsakatira et al., 2018). The treatment is mainly performed using larvae of black soldier fly (Hermetia illucens) but can also be performed using larvae of other fly species, such as common housefly (Musca domestica) or blowfly (family Calliphoridae).

All studies show a decrease in salmonellae numbers during fly larvae treatment compared with untreated controls. In S. enteritidis, Erickson et al. (2004) found a $1 \log _{10}$ reduction within 3 days and an even greater reduction with longer treatment time. In $S$. Typhimurium in faecal matter, Lalander et al. (2013) found a reduction of over $6 \log _{10}$ in 8 days in treatment with larvae, compared with just over 1 $\log _{10}$ reduction during storage at room temperature. Those authors also found that 8 days of treatment were enough to ensure that no detectable salmonellae remained in any of the material, including inside and outside the larvae, from a starting concentration above $6 \log _{10}$ per $g$ of faeces (Lalander et al., 2013).

Investigations into the mechanisms responsible for Salmonella spp. inactivation during fly larvae treatment indicate that the larvae treatment process generate antibacterial substances, either from the larvae or from bacteria in the process, decreasing the number of bacteria inside the larvae gut (Mumcuoglu et al., 2001), as well as protein or lipid substances that have an additional effect in treating the substrate. No studies have been performed on the risk of re-growth in the material during post-treatment 
storage. However, the indication of excretion of antibacterial substances by the larvae indicates continued kill-off of any salmonella present.

Vermicomposting has similar effects on Salmonella spp. to fly larvae composting (Lalander et al., 2013; Lalander et al., 2015). The main difference is the actual vermicomposting process, which is more often run as a continuous process, with the risk of cross-contamination from migrating worms. In summary, fly larvae composting in batches during at least one week is sufficient to reduce Salmonella spp. to very low concentrations. The compost material and the larvae will then be safe from a Salmonella contamination perspective. Batch-wise vermicomposting has similar effects, but takes a longer time for full removal of Salmonella spp.

\subsubsection{Composting}

The main effect within composting is related to heat inactivation. The composting itself may have some effect in reducing salmonella numbers during the process, due to a combination of heat and chemicals produced during degradation, such as ammonia, carbonate and organic acids (Singh et al., 2012). The self-heating of the compost is very effective in sanitizing the material, but to achieve this effect it is important to keep the heat within the compost. This is best done by having a large enough pile/windrow (at least $1.2 \mathrm{~m}$ high) or an insulated reactor (Haug, 1993). However, there may be major differences in temperature in different parts of the compost, so to have an efficient removal of salmonellae, the compost needs to be turned several times so that all the material is treated (Berry et al., 2013). As a rule of thumb, reactors should be mixed three times and windrows should be mixed five times with time between turnings long enough for pathogen inactivation within the thermophilic area (Vinneras, 2013; Vinneras et al., 2010).

The main effect of the composting process derives from stabilisation of the material and from providing competing bacteria to decrease the risk of re-growth of salmonella that have survived the process or that have been carried in by vectors or by cross-contamination within the process. Elving et al. (2010) compared the risk of re-growth of $S$. Typhimurium during composting of food waste and manure in relation to the level of maturity of the compost, measured with Solvita ${ }^{\mathrm{TM}}$ tests. They found an inverse correlation between compost maturity and rate of Salmonella re-growth. On comparing different temperatures, they found that at mesophilic temperatures $\left(37^{\circ} \mathrm{C}\right)$, Salmonella growth in less mature compost was fast, increasing by $2-3 \log 10$ during the first days of incubation and thereafter decreasing slowly, but never to below the initial count during the 8 days of the study. Salmonella growth was slower at psychrophilic temperatures $\left(14^{\circ} \mathrm{C}\right)$, taking up to 8 days to reach the same level as at $37^{\circ} \mathrm{C}$. In matured composts, there was no growth or in some cases even a decrease in Salmonella concentration (Elving et al., 2010). Miller et al. (2013)observed similar effects, with growth of $1 \log 10$ during the first day at $24^{\circ} \mathrm{C}$ in material with a lower stabilization level (bone meal) than manure-based fertilizers, which are normally composted for a very long time prior to use
In summary, composting is a good stabilisation method and can prevent re-growth and re-contamination by Salmonella spp. (Sidhu et al., 2001; Elving et al., 2010; Miller et al., 2013). For sanitation, temperatures above $50^{\circ} \mathrm{C}$ are required, combined with mixing, as the material can have an uneven temperature distribution. Repeated mixing during the thermophilic phase ensures that most of the material reaches the higher temperature required to inactivate microbes. To reach a high level of pathogen removal, most of the material needs to be treated, e.g. a 5 $\log _{10}$ reduction requires $99.999 \%$ of the material to be treated at a high enough temperature and that no regrowth occurs in zones with lower temperatures.

\subsection{Disinfection}

In treatment of substrates to reduce the Salmonella spp. content, when using natural substrates like faecal sludge and different sewage fractions it is difficult to isolate the single pathogen inactivation factor. Inactivation can be due to a combination of temperature, $\mathrm{pH}$ and toxic chemical substances, e.g. ammonia or organic acids. The survival of Salmonella spp. cells is regulated by several different stress responses that protect the cells in the environment, but all these are energy consuming and thus the survival will also depend on the availability of energy to the cells. For most treatments evaluated, Escherichia coli can be used as a somewhat more sensitive indicator of treatment efficiency regarding inactivation of Salmonella spp.

\subsection{1 pH (lime, ammonia)}

The two main chemical treatment systems used in water and wastewater disinfection are high $\mathrm{pH}$ and oxidation. Liming is a classic high $\mathrm{pH}$ treatment that has been used on sludge, surfaces and liquids for over a century. The goal of liming is to raise the $\mathrm{pH}$ of the matrix above 10 , a value at which most organisms cannot survive. In high $\mathrm{pH}$ treatments, the effect of increased $\mathrm{pH}$ can be separated into two different functions, one related to ammonia (NH3) concentration and one related to $\mathrm{pH}$. As higher $\mathrm{pH}$ allows for a larger proportion of ammonia to be present in the uncharged toxic form, ammonia has a faster effect than just elevated $\mathrm{pH}$ alone, as it affects microbial cells that prefer lower $\mathrm{pH}$. However, if only a small $\mathrm{pH}$ elevation is achieved by liming, the treatment can still be effective, because a small increase in $\mathrm{pH}$ leads to higher concentrations of basic, biocidal matrix constituents, such as ammonia and carbonate. These substances in turn contribute to pathogen inactivation. Lime treatment thus has multiple routes by which inactivation can be achieved, although they are all ultimately based on raising the $\mathrm{pH}$.

Mechanisms of inactivation: High $\mathrm{pH}$ inactivates Salmonella cells by raising the intracellular $\mathrm{pH}$, which ultimately leads to collapse of intracellular functions. Alternatively, the organisms may starve because all of their energy must be spent on actions to compensate for the high extracellular pH. For example, most non-extremophile bacteria maintain a stable internal $\mathrm{pH}$ of about 7.4-7.9, but survive or even grow over a considerably larger external $\mathrm{pH}$ range of 5.5-9 (Padan et al., 2005). At higher $\mathrm{pH}$ levels, cation/proton antiporters in most non-extremophile bacterial cell membrane export cations such as sodium $(\mathrm{Na}$ + ), in exchange for importing hydrogen $(\mathrm{H}+)$. This energy- 
consuming process is employed to maintain the intracellular $\mathrm{pH}$ within an optimal range. In combination with other stress factors, such as low redox potential and high temperatures, the sensitivity to high extracellular $\mathrm{pH}$ increases. Therefore, treatment with burnt lime $(\mathrm{CaO})$ can be considerably more efficient than treatment with slaked lime $(\mathrm{Ca}(\mathrm{OH}) 2)$, as the burnt lime increases not only the $\mathrm{pH}$, but also the matrix temperature.
Ammonia has a rapid effect on Salmonella cells even at low concentrations (Figure 2). Inactivation of Escherichia coli by ammonia is similar to inactivation of Salmonella spp. and therefore E. coli can be used as an indicator for inactivation of Salmonella. An ammonia concentration of $10 \mathrm{mM}$ is enough for inactivation, with decimal reduction values (D-values) lower than 100 days and in most cases considerably lower than 10 days. The advantage with ammonia treatment is that the ammonia is not consumed during the process and, as long as ammonia remains in the matrix, in combination with elevated $\mathrm{pH}$, there is no risk of re-growth or re-contamination.

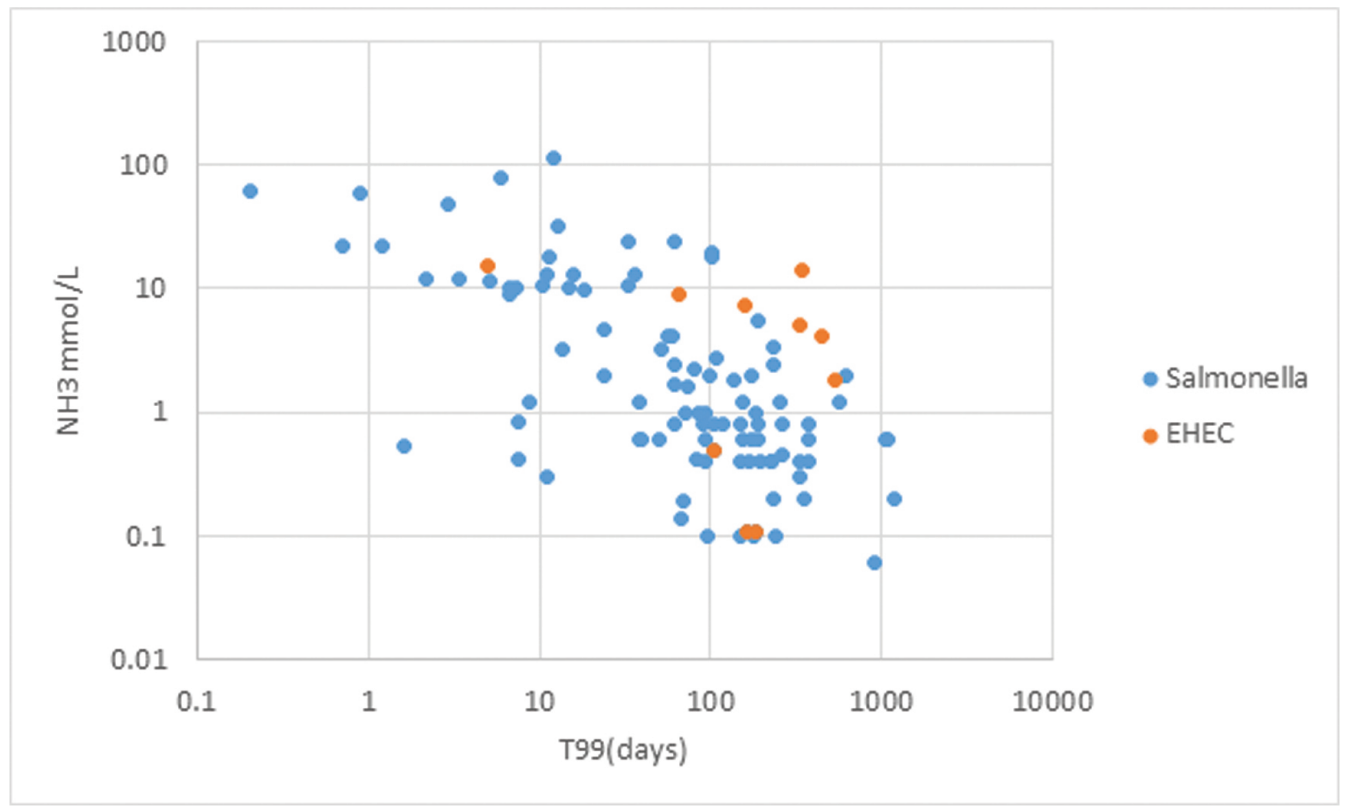

Figure 2. Decimal reduction (D) values (minutes) for 99\% inactivation of Salmonella spp. and enterohaemorrhagic Escherichia coli 0157 (EHEC) in relation to the concentration of uncharged ammonia $\left(\mathbf{N H}_{3}\right)$ (Ellis et al., 2018; Paluszak et al., 2003; Pepper et al., 1993; Arrus et al., 2006; Semenov et al., 2009; Danyluk et al., 2008; Ongeng et al., 2015; Cote and Quessy, 2005; Olsen and Larsen, 1987; Smith et al., 2005; Padan et al., 2005; Vinneras et al., 2008; Vinneras et al., 2003; Ottoson et al., 2008).

\subsubsection{Acids}

There are two levels of acid-related inactivation of salmonellae: low $\mathrm{pH}$ and use of organic acids with higher chemical toxicity than inorganic acids. Organic acids are often used in food preservation, with good success (Huss et al., 2017), while direct use of organic acids for treatment of wastes is less common. A number of studies show that presence of organic acids assists in microbial inactivation during other biological treatments, such as anaerobic digestion. As acids in the environment play an important role in inactivation of salmonella, several defence mechanisms have developed in the bacteria. According to Loewen and Hengge-Aronis (1994), there are similarities in gene expression of the response of Salmonella spp. regarding thermal and chemical stress, where the sigma factor independently, or together with other regulatory transcription factors, is responsible for the chemotactic response. The stress responses of the cells result in a 
completely different structure and activity within cells, which enter a form of dormant stage during stress (Spector and Kenyon, 2012). Spector and Kenyon (2012) show that seven different stress responses are involved in managing acid stress, while only four are involved in managing heat stress. The genetic $\sigma$ HSE factor is involved in three of these responses, for management of both acid and heat stress. However, in a study examining the inactivation kinetics of 60 S. enterica strains, Lianou and Koutsoumanis (2013) found no correlation between Salmonella spp. survival in relation to heat or acid stress $\left(\mathrm{pH} 3(\mathrm{HCl}), 37^{\circ} \mathrm{C}\right)$ or in relation to aryl hydrocarbon receptor (AMR) and the acid resistance of a specific strain. Lianou and Koutsoumanis (2013) also evaluated the acid sensitivity of 30 Salmonella strains at $\mathrm{pH} 3$ during 4 hours at $37^{\circ} \mathrm{C}$ and found that growing the strains in an acid environment decreased the reduction rate in most cases, while 23 out of 30 strains also showed acid resistance build-up in $S$. enterica, indicating that it is strain-dependent. The inactivation rate at $\mathrm{pH} 3$ at $37^{\circ} \mathrm{C}$ varied between a decimal reduction in 42 minutes and up to 4.8 hours (Lianou and Koutsoumanis, 2013). In another study, a moderate decrease in $\mathrm{pH}$ (to $\mathrm{pH}$ 5) was not sufficient to create a hysteresis reaction in the cells of $S$. Typhimurium and no specific gene activity was detected after neutralising the medium to pH 7 (Pin et al., 2012). Erickson et al. (2014) developed a model for Salmonella inactivation at mesophilic composting temperatures related to $\mathrm{pH}$ and time with temperatures above $40^{\circ} \mathrm{C}$, where the main effect of the inactivation was related to production of volatile fatty acids. The study showed a decimal reduction in 7 to 37 hours (the lower the $\mathrm{pH}$, the faster the inactivation of Salmonella), indicating that the uncharged acid is the toxic form. As with the other chemical treatments, higher temperature increased the chemical-induced inactivation rate, mainly due to more permeable membranes (Erickson et al., 2014).

The effect of acids needs to be generally quantified in future studies. When using acids for Salmonella inactivation, each treatment system needs to be validated regarding the actual inactivation rate in that system. Important factors to be monitored in this regard are $\mathrm{pH}$, temperature, and type of acid.

\subsubsection{Thermal treatment}

The effect of heat treatment on Salmonella spp. varies widely depending on the material treated. Many studies have examined heat inactivation of the microbes, but most consider heat treatment of food and feed-related substrates, rather than wastes. Most report the D-value or z-value (number of degrees by which the temperature has to be increased to achieve a $1 \log 10$ reduction in D-value), irrespective of the substrate. The lowest temperature at which inactivation has been detected is $47.5^{\circ} \mathrm{C}$ (Elving et al., 2014) and some studies report effective inactivation at $50^{\circ} \mathrm{C}$, but most previous studies have been performed at temperatures of $55^{\circ} \mathrm{C}$ and above (Figure 3). In addition, some data on $\mathrm{E}$. coli have been produced in studies examining whether it can be used as a model for Salmonella regarding heat inactivation. The data show that E. coli can be used as model for heat inactivation of Salmonella spp., as the inactivation rates ( $D$-values) are within the same range for both bacteria types. However, E. coli seems to correspond to the lower range of $\mathrm{D}$-values reported for Salmonella spp. (Buzrul and Alpas, 2007; Jin et al., 2008; Lang and Smith, 2008; Rakowski, 2012)(Figure 3).

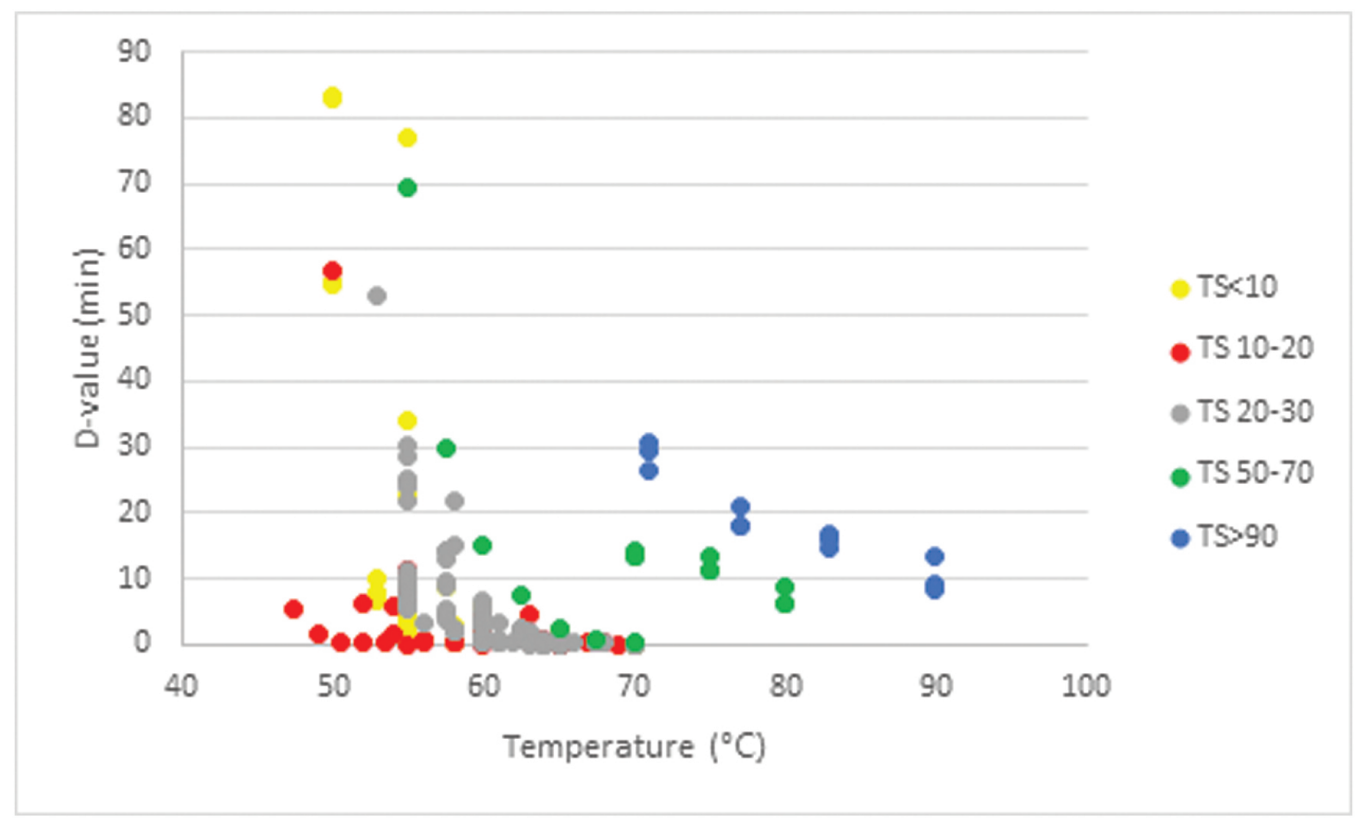

Figure 3. Decimal reduction (D) values (minutes) for $90 \%$ inactivation of Salmonella spp. as a function of treatment temperature during thermal inactivation for substrates with different total solids (TS in percent) content (Elving et al., 2014; Buzrul and Alpas, 2007; Jin et al., 2008; Lang and Smith, 2008; Rakowski, 2012; Soldierer and Strauch, 1991; Eckner, 1992; Duffy et al., 1995; OrtaRamirez et al., 1997; Veeramuthu et al., 1998; Murphy et al., 1999; Mazzotta, 2000; Murphy et al., 2000; Smith et al., 2001; Bolton et al., 2003; Kumar and Kumar, 2003; Manas et al., 2003; Murphy et al., 2003; Spinks et al., 2006; Juneja, 2007; Osaili et al., 2007; Ma et al., 2009; Monfort et al., 2011; Kim et al., 2012; Burns et al., 2016; Hildebrandt et al., 2016). 
Duffy et al. (1995) found a major difference in the survival rate of S. Typhimurium heat-treated in a buffer solution at a particular temperature in relation to the number of other competing organisms, with higher survival with higher concentrations of other bacteria. In that study, the initial concentration of Salmonella was 6 $\log 10$ and the number of competing organisms increased from zero to $8 \log 10$ during the heat treatment. Velliou et al. (2013) observed similar effects when using higher counts of S. Typhimurium, with a population of about 8 $\log 10$ being more heat tolerant, i.e. having a higher D55value, than less dense solutions. S. Senftenberg $775 \mathrm{~W}$ has been used in several studies and in some cases shows higher thermal resistance than other strains tested
(Jarvis et al., 2016). However, when looking at all evaluated Salmonella spp. compared with S. Senftenberg, there is no trend for higher D-value in the latter (Figure 4). Other factors during treatment have a greater impact on the survival at different heat treatment temperatures. One factor found to have a substantial impact on the survival of Salmonella spp. is the stage of bacterial growth at the start of the trial, where bacteria at the lag phase have a higher survival rate than bacteria at the log stage. Other important factors are the number of bacteria in the material (where a higher bacteria count $(8 \log 10)$ either of Salmonella spp. or other bacteria, results in increased survival), the composition of the substrate itself, and how the heat is transferred within the material (Figure 4).

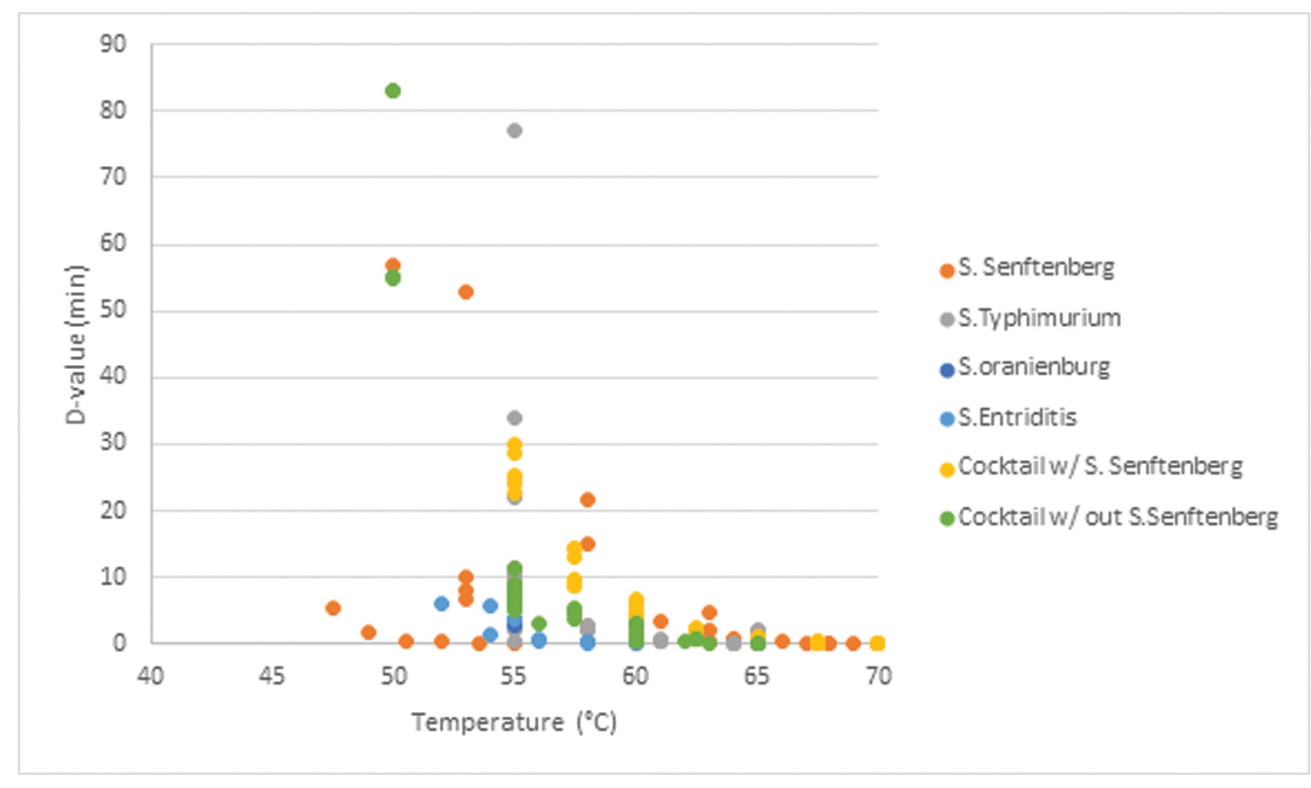

Figure 4. Decimal reduction (D) values (minutes) for $90 \%$ inactivation of different Salmonella strains in material with a dry matter content $<\mathbf{3 0} \%$ heat-treated at different temperatures. Cocktail of all strains, with and without $S$. Senftenberg, is compared (Elving et al., 2014; Buzrul and Alpas, 2007; Jin et al., 2008; Lang and Smith, 2008; Rakowski, 2012; Soldierer and Strauch, 1991; Eckner, 1992; Duffy et al., 1995; OrtaRamirez et al., 1997; Veeramuthu et al., 1998; Murphy et al., 1999; Mazzotta, 2000; Murphy et al., 2000; Smith et al., 2001; Bolton et al., 2003; Kumar and Kumar, 2003; Manas et al., 2003; Murphy et al., 2003; Spinks et al., 2006; Juneja, 2007; Osaili et al., 2007; Ma et al., 2009; Monofort et al., 2011; Kim et al., 2012; Burns et al., 2016; Hildebrandt et al., 2016).

Duffy et al. (1995) concluded that the longer survival in some Salmonella species is related to the cells being in a stationary phase mediated by the genetic os factor, thereby increasing the thermal resistance of the organism. Within species, the heat resistance of $\mathrm{S}$. Senftenberg is greater when it is stressed by heat shock after overnight heat adaptation at $45^{\circ} \mathrm{C}$ (Kumar and Kumar, 2003). Similar results have been found for $S$. Senftenberg, S. Enteritidis and S. Typhimurium grown at different temperatures $(10,20,37,40)$, with higher Dvalues obtained with higher growth temperature (Manas et al., 2003). However, the z-values do not seem to be affected by the growth temperature. The memory of the cell regarding heat protection persists for at least 30 minutes, as indicated by the tailing off in heat-induced gene expression, with 187 upregulated genes still remaining out of 373 upregulated genes during heat treatment at $45^{\circ} \mathrm{C}$ (Pin et al., 2012). 
Several studies report substantial variation in the D-value of a specific strain in relation to the substrate within which it is heat-treated (Jin et al., 2008; Lang and Smith, 2008). A decrease in substrate moisture content results in increased resistance of Salmonella spp. to heat, mainly due to decreased heat transfer capacity (Kim et al., 2012; Bischel et al., 2016). A similar effect is found for the zvalues, with materials with a dry matter content up to $30 \%$ having a similar z-value of $5.5 \pm 1$. However, when the dry matter content increases above $50 \%$, the z-value increases to well above 30 . On the other hand, the $\mathrm{z}$ value has been found not to be affected by the substrate as long as a similar dry matter content is maintained (Jin et al., 2008; Murphy et al., 1999; Murphy et al., 2000) (Figure 5).

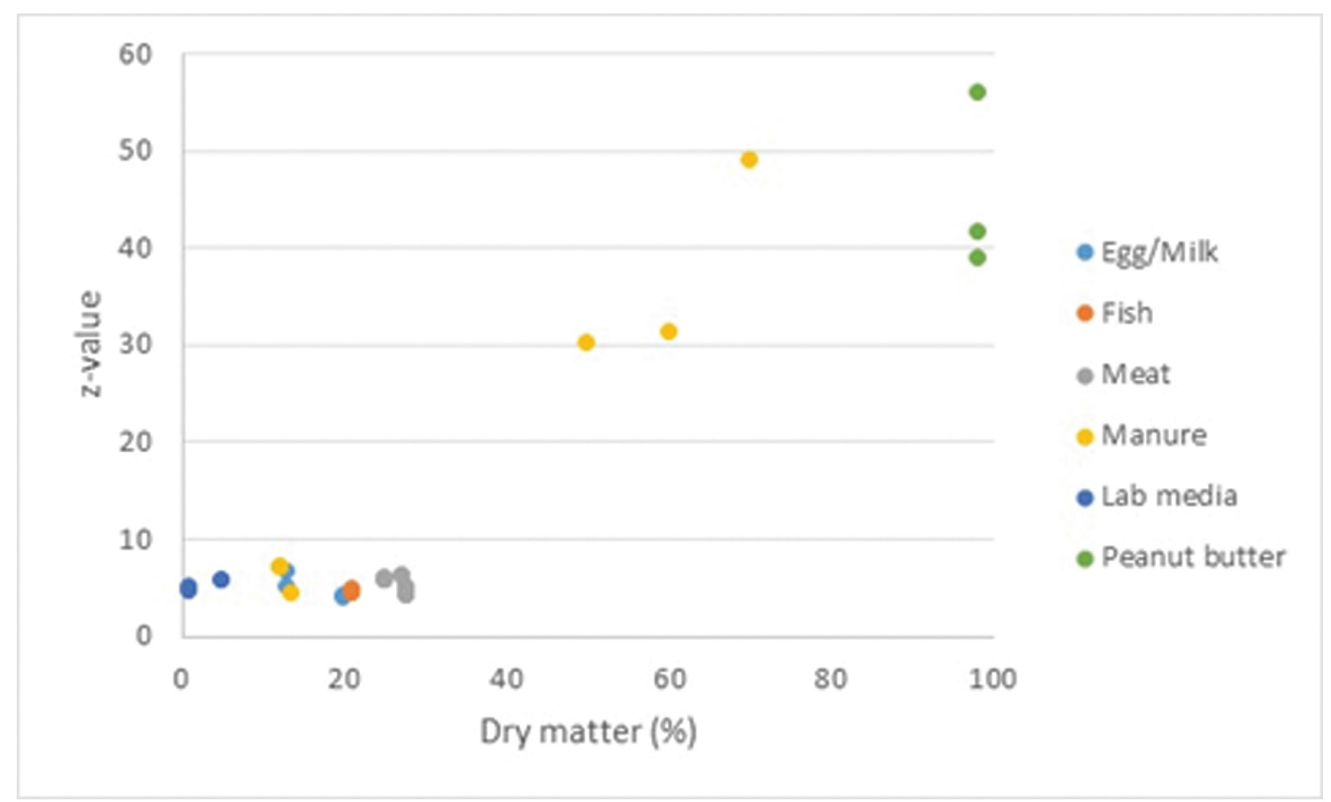

Figure 5. Increase in temperature $\left({ }^{\circ} \mathrm{C}\right.$ ) necessary to change the decimal reduction value (D) by a factor of 10 (z-value) of 16 different Salmonella strains, present either individually or as a cocktail of four to eight strains, in material with different dry matter content (Jin et al., 2008; Rakowski, 2012; Soldierer and Strauch, 1991; Eckner, 1992; OrtaRamirez et al., 1997; Murphy et al., 1999; Mazzotta, 2000; Smith et al., 2001; Manas et al., 2003; Ma et al., 2009; Kim et al., 2012).

Heat-damaged salmonellae cells show great variation in the lag phase before rapid re-growth, with a lag phase of up to $20 \mathrm{~h}$ and with notable variation in recovery in relation to the broth used (Stephens et al., 1997). In that study, there were no correlating factors for the effect of the different broths used and duration of the lag phase. The growth temperature also affected the lag phase, e.g. $25^{\circ} \mathrm{C}$ resulted in a longer lag phase than $37^{\circ} \mathrm{C}$ (Juneja and Marks, 2006). Moreover, studies have shown that recovery of heatdamaged cells is higher under reduced oxygen conditions (George et al., 1998).

Humpheson et al. (1998) suggest that biphasic thermal inactivation kinetics should be used for heat inactivation of Salmonella at temperatures above $51^{\circ} \mathrm{C}$. They attribute the tailing in inactivation mainly to formation of heat shock proteins that preserve the cells of a small subpopulation with a considerably higher D-value. During heat treatment, there are several possible explanations for prolonged survival of individual Salmonella cells, such as protective particles and uneven heat distribution in the material
(Haug, 1993). It is therefore important to know the properties of the material to be treated before planning a specific treatment method.

In summary, there is a rapid decrease in the D-value of Salmonella spp. with increased temperature in the range $50-60^{\circ} \mathrm{C}$. The most important factor is the dry matter content of the material, as the D-value and the z-value increase with dry matter content above 30\%. At the lower range of dry matter content, the most important factor for proper inactivation is achieving uniform heat distribution in all the material. For full inactivation of Salmonella spp., the temperature should at least be above $47.5^{\circ} \mathrm{C}$ and preferably above $55^{\circ} \mathrm{C}$. Even at $55^{\circ} \mathrm{C}$, the time required for a decimal reduction (D-value) can be above 1 hour. For validation of the process, a cocktail of several Salmonella spp. types should be used and the D-value and z-value for inactivation in the specific substrate should be determined. A heat map of the process is also required, to ensure that the time and temperature requirements are met within the process. 


\section{Appendix A. Methods for detection of Salmonellae}

\section{A.1 Culture methods}

Pre-enrichment uses a nutritious, nonselective medium to recover sub-lethally injured salmonellae cells. Buffered peptone water (BPW) is a commonly used primary enrichment medium for environmental samples as well as in food microbiology whereas CEN/TR 15215:2006 for characterization of sludges suggest BPW supplemented with the antibiotic Novobiocin. For detection of $S$. Typhi and $S$. Paratyphi serovars, selenite cysteine (SC) broth or universal pre-enrichment (UP) broth is recommended by standards/guidelines for environmental samples as the first enrichment step (See Table 4).

Primary pre-enrichment is followed by inoculation into selective media containing inhibitory reagents to allow for further growth of salmonellae, while suppressing other bacteria. Traditionally, three types of selective enrichments are used: tetrathionate media (TT and MKTTn broth), selenite-based media (SC broth) and Rappaport media (RV, RVS and MSRV). Rappaport-Vassiliadis media (with malachite green and magnesium chloride as suppressive agent) have for the enrichment step shown more sensitive than SC and TT broth (Mooijman, 2012) and is the primary choice by several reference methods for environmental samples. However, for $S$. Typhi detection in fruit, enrichment in SC and TT broths proved much more efficient than RV medium (Hammack et al., 2008) and is also recommended by ISO 6579 for the detection of $S$. Typi and $S$. Paratyphi. MKTTn can also recover some strains of $S$. Paratyphi, but not S. Paratyphi C (ISO 19250:2010). Selenite enrichment has otherwise been used most frequently for the isolation of salmonellae when direct enrichment of the sample in selective media is recommended, e.g., with stool or organ samples (Mooijman, 2012). To account for the varying selectivity of media, food microbiology reference methods have often prescribed the use of two enrichment media of different groups in parallel. Motility enrichment in semi-solid agar (e.g., MSRV; DIASALM; SMS-agar), based on swarming of motile salmonellae, functions by both enriching and indicating presumptive salmonellae in one step. Semi-solid media have shown significantly higher sensitivity compared to liquid media (De Busser et al., 2013) and MSRV is currently part of several reference methods for environmental samples.

To isolate presumptive positive salmonellae colonies, which requires inhibition of the growth of other bacteria, the selective enrichments are plated on one or more selective media in parallel. Selective plating agars rely on different selective agents, indicator systems and differential characteristics to distinguish Salmonella spp. from related enteric bacteria and may also to some extent be used to differentiate between different salmonellae. It is often recommended to use at least two plating media based on different selective agent and indicator systems, since no plating agar can detect all salmonellae serovars.
Chromogenic media, which exploit substrates that release colored dyes upon enzymatic hydrolysis, generally have higher specificity than traditional selective media and may be suitable for environmental samples with varying background flora. Chromogenic media helps also reduce the potential for false-positives selected for further testing. Many of the chromogenic media currently in use for salmonellae are based on C8-esterase activity or $\alpha$ galactosidase, whereas $\beta$-galactosidase is used for differentiating between other enterobacteriaceae (Perry, 2017). Chromogenic media can also be sprayed onto nonchromogenic agar for further differentiation, e.g., between Salmonella spp. and Citrobacter spp. (CEN/TR 15210:2006). Fluorogenic salmonellae media generally differentiate salmonella from $E$. coli by fluorescence in the latter. Currently, there are several chromogenic agars that are sold under different brand names for which composition is not fully reported (Table 4). Several reference methods for food and environmental samples (Table 5) include Brilliant green (BG) agar, Xylose-lysine-deoxycholate (XLD) agar, and Rambach agar (Table 4) as solid media for Salmonella spp. isolation. XLD agar may work well for most salmonellae isolates, although H2S-negative and/or lactose fermenting strains may result in non-typical appearance. Some salmonellae strains, including $S$. Typhi and $S$. Paratyphi, and some strains of $S$. Typhimurium and $S$. Dublin, may, however, be inhibited by brilliant green, the dye used in BG agar (Curtis and Clarke, 1994). Salmonella Typhi, though, will display typical growth on Miller-Mallinson (MM) medium, which also will distinguish lactose-positive Salmonella spp. from coliforms by their $\mathrm{H}_{2} \mathrm{~S}$ production. MM medium is suggested by US EPA (2010), together with Bismuth-sulfite (BS), for analyses specifically targeting $S$. Typhi in drinking water. Also, the abchromogenic (ABC) medium results in typical growth of $S$. Typhi and $S$. Paratyphi A and B. On Rambach agar $S$. Typhi, $S$. Paratyphi A and B, as well as strains of $S$. bongori (V) and S. enterica subsp. arizonae (IIIa) and diarizonae (IIIb), may appear atypical (Kuhn et al., 1994).

Presumptive salmonellae colonies isolated on solid media are subsequently subjected to several biochemical tests and serological identification. Common biochemical tests for salmonellae are based on fermentation of selected substances (e.g., citrate, glucose, mannose, inositol, sorbitol, rhamnose, sucrose, melibiose, amygdalin, arabinose) and production of enzymes ( $\beta$-galactosidase; decarboxylases, urease, tryptophan deaminase, tryptophanase, gelatinase etc.). Commonly applied reference methods tests include triple sugar iron agar (TSI), lysine iron agar (LIA), urease- and indole test (Table 4). Some of these tests include several aspects for identification of salmonellae, e.g., $\mathrm{H}_{2} \mathrm{~S}$ production in combination with sugar fermentation (in TSI) or L-Lysine decarboxylation (in LDC test). Test strips, such as the Analytical Profile Index kit (API 20E), include miniaturized versions of several biochemical tests with the purpose of differentiating among bacteria in the Enterobacteriace family (Tables 4 and 5).

Selective enrichment media given by standard methods for environmental samples presently includes MSRV, RVS, RV 
and MKTTn for salmonellae in general and SC broth for detection of $S$. Typhi (Table 4). In addition to selective agents, an elevated incubation temperature (approximately $42^{\circ} \mathrm{C}$ ) of the medium will further inhibit the growth of interfering background flora but is not recommended if salmonellae are assumed present in low concentrations. For samples with relatively high amounts of background flora, the semi-solid media MSRV and DIASALM, based on salmonellae motility, have shown to be very effective for the detection of salmonellae (Voogt et al., 2001). However, it has been observed that the use of semi-solid agar as a selective enrichment seems to favor the development of $S$. Enteritidis (Svastova et al., 1984; Perales and Erkiaga, 1991; Poppe et al., 1992). As selective plating media XLD is predominantly recommended by environmental standard methods (Table 6). As different culture media may have different sensitivity for different salmonella serovars, the objectives for a particular environmental analysis may determine the choice of media or that media with different specificity shall be used in parallel. $S$. Typhi and specifically $S$. Paratyphi, non-motile salmonellae and lactose positive salmonellae that also are $\mathrm{H}_{2} \mathrm{~S}$ negative, may potentially be overlooked by the standard methods (Table 6). The relevance to determine the subspecies, serotype or features as antimicrobial resistance of Salmonella in environmental samples may be highly dependent of the scope of the sampling (Table 4 and 5). It's worth mentioning that since the formulation, validation, review and agreement of standards typically requires several years, standard methods may not cover the latest method developments and optimal media and methodology in current research may show a significant departure from media and methods given by standards.

In the VBNC state, bacteria fail to grow on conventional growth media, but still maintain metabolic functions and cell integrity. Culture methods thus risk underestimation of total viable cells (Li et al., 2014). In the food industry, the VBNC state has been shown to be induced by disinfectants used in food hygiene (Gruzdev et al., 2011; Highmore et al., 2018) or sterilization techniques (Liao et al., 2018) and food preservation measures, e.g. dehydration, heat treatment, cold storage and acid treatment (Gruzdev et al., 2011; Gruzdev et al., 2012; Morishige et al., 2017; Xu et al., 2008). Also the environment will subject Salmonella spp. to stresses as osmotic-, nutritional-, heat- and cold stress. Fu et al. (2015) found that the VBNC state of Salmonella spp. and Shigella spp. in sewage sludge was induced to a higher degree (four orders of magnitude) during thermophilic anaerobic digestion compared to mesophilic digestion. As a result, the $S$. Typhimurium concentration in thermophilic digested sludge after cake storage were two orders of magnitude higher than for mesophilic digested sludge. When simulating starvation in aquatic environment, VBNC states for most of the Salmonella population studied was induced in 30 minutes to 5 weeks (Chmielewski and Frank, 1995; Baleux et al., 1998). Idil et al. (2011) studied the effect of UV-A and different wavelengths of visible lights on $S$. Typhimurium in seawater microcosms found that visible red light induced the largest shift to VBNC. These studies indicate that VBNC states are likely to be induced in environment, even though not frequently studied. In general, VBNC cells have higher physical and chemical resistance than culturable cells (Li et al., 2014), which make them not just undetectable, but also increases their persistence in the environment. An extreme case is the resuscitation of $S$. Typhimurium incubated in seawater and soil microcosms for 20 years (Dhiaf et al., 2010). To account for VBNC subpopulations, alternative methods for determining viability have been developed based on demonstration of cellular integrity, physiological responsiveness/metabolic activity or presence of nuclei acids (Keer and Birch, 2003). Direct count of bacterial cells with the viability indicated by staining in relation to different integrity/activity aspects is used to assess and enumerate VBNC bacterial subpopulations. Alternatives to cell counting include the use of flow cytometry and fluorescent staining techniques, the exploitation of physiological responsiveness or metabolic activity.

\section{A.2 Immunology and nucleic acid based tests}

The immunology-based methods for salmonellae detection utilize antibodies, which complex with antigens that are normally located on the cellular membrane surface of salmonellae. Depending on the formulation, the applied antibodies can serve different purposes: identification/differentiation (e.g., agglutination; serotyping; immunoprecipitation), separation/concentration (immunomagnetic separation), or detection with indirect quantification of the targeted pathogen (LFIA, EIA/ELISA). In combination with culture media, as in immunodiffusion assays, antibodies are also used as an integrated identification/confirmation step, thus reducing the time to confirm salmonellae. Agglutination and serotyping are commonly used as confirmatory steps for culture-based methods and yields clear and rapid typing down to serogroup. Lateral flow immunoassays (LFIA), often formulated as paper-based platforms, may display results within 5-30 min. Such assays have important clinical value of being rapid and easy to interpret. The small sample that is absorbed into the LFIA means that the detection limit is rather high, and that the media only can perform direct testing on water samples. The specificity is high (to serovar level), whereas sample preparation is necessary for fecal material as well as environmental samples due to the low detection limits, often $\geq 10^{6}$ cells per $\mathrm{ml}$.

EIA/ELISA-based methods are considered to be particularly promising for rapid detection because they combine the specificity of the antibodies with the sensitivity of the enzymatic assays by coupling easily assayed enzymes to antibodies or antigens. Usually, EIA/ELISA are more selective and sensitive than agglutination or immunoprecipitation assays, but they need more time to obtain quantitative results. Still, the time required is typically less than that of most nucleic acid-based methods.

Nucleic acid-based assays detect a specific DNA or RNA target sequence within the Salmonella genome by matching complementary sequences of single-stranded DNA or RNA to pair with each other. Two major categories of nucleic acid-based assays are direct hybridization (DNA probe) and amplification methods, such as polymerase chain reaction 
(PCR). Many primer sets have been developed to target various genes specific to both the genus and species level of Salmonella using both PCR and quantitative PCR (qPCR) (Table A1). These assays can target many different levels of specificity in Salmonella. Often the invA gene is targeted for detection of salmonella at the genus level. Detection of species and subspecies varies widely.

Table A1. Molecular-based assays used for Salmonella genus detection and identification

\begin{tabular}{|c|c|c|c|c|}
\hline $\begin{array}{l}\text { Targeted } \\
\text { Species }\end{array}$ & $\begin{array}{c}\text { Targeted } \\
\text { Subspecies }\end{array}$ & $\begin{array}{l}\text { Target } \\
\text { Gene }\end{array}$ & Primer Set $\left(5^{\prime}-3^{\prime}\right)$ & Reference \\
\hline All & All & invA & $\begin{array}{l}\text { PCR-F:GTGAAATTATCGCCACGTTCGGGCAA, } \\
\text { R:TCATCGCACCGTCAAAGGAACC }\end{array}$ & $\begin{array}{c}\text { Rahn et al., } \\
1992\end{array}$ \\
\hline All & All & invA & $\begin{array}{c}\text { qPCR-F: GCGTTCTGAACCTTTGGTAATAA } \\
\text { R: CGTTCGGGCAATTCGTTA, Probe: } \\
\text { FAM-TGGCGGTGGGTTTTGTTGTCTTCT-TA } \\
\text { MRA }\end{array}$ & $\begin{array}{l}\text { Daum et al., } \\
2002\end{array}$ \\
\hline All & All & ttrRSBCA & $\begin{array}{c}\text { ttr-6 F: CTCACCAGGAGATTACAACATGG } \\
\text { ttr-4 R: AGCTCAGACCAAAAGTGACCATC Target } \\
\text { probe (ttr-5) FAM-CACCGACGGCGAGACCGACTTT- } \\
\text { Dark Quencher }\end{array}$ & $\begin{array}{l}\text { Malorney et al., } \\
\qquad 2004\end{array}$ \\
\hline enterica & All & iroB-192 & $\begin{array}{l}\text { F: CCAAGAGATCTGGCGTGGATA } \\
\text { R: TATTGCATGGAGATAACCGGCT }\end{array}$ & $\begin{array}{l}\text { Murphy et al., } \\
2007\end{array}$ \\
\hline enterica & All & iroB-12 & $\begin{array}{l}\text { F: GGRACAAAAATGGGGMACTTCT } \\
\text { R: AAGGGGAGGRTAGACGATGA }\end{array}$ & $\begin{array}{l}\text { Barbau-Piednoir } \\
\text { et al., } 2013\end{array}$ \\
\hline enterica & Enterica & safC-10 & $\begin{array}{l}\text { F: CACTAAAAAGTCGTCTGACTCTGG } \\
\text { R: CGGTAAATGGCACACTATCAAAT }\end{array}$ & $\begin{array}{l}\text { Barbau-Piednoir } \\
\text { et al., } 2013\end{array}$ \\
\hline enterica & Enterica & safC-13 & $\begin{array}{l}\text { F: ATGATGACAGCTACGGACTGAGTT } \\
\text { R: CTGTTTTGATTCCAGTTCAATGAC }\end{array}$ & $\begin{array}{c}\text { Barbau-Piednoir } \\
\text { et al., } 2013\end{array}$ \\
\hline enterica & Enterica & STM0296 & $\begin{array}{l}\text { F: AMGCCCATCCCTTCAATACAG R: } \\
\text { GTGATYACGCCGCAGCATACCC }\end{array}$ & $\begin{array}{l}\text { Barbau-Piednoir } \\
\text { et al., } 2013\end{array}$ \\
\hline enterica & Typhi & $\begin{array}{l}\text { STY0201, } \\
\quad \text { staG }\end{array}$ & $\begin{array}{c}\text { F: CGCGAAGTCAGAGTCGACATAG } \\
\text { R: AAGACCTCAACGCCGATCAC } \\
\text { Probe: FAM-CATTTGTTCTGGAGCAGGCTGACGG-TAMRA }\end{array}$ & Nga et al., 2010 \\
\hline enterica & Paratyphi & SSPA2308 & $\begin{array}{c}\text { F: ACGATGATGACTGATTTATCGAAC, } \\
\text { R: TGAAAAGATATCTCTCAGAGCTGG , } \\
\text { Probe:CCATACAATTTCATTCTTATTGAGAATGCGC-BHQ5[ }\end{array}$ & Nga et al., 2010 \\
\hline enterica & Paratyphi & SPC0869 & $\begin{array}{c}\text { F: CTGGCTGACACATGAACAAATC, } \\
\text { R: CCTGAGAACGAGTCAGGTTTAC, } \\
\text { Probe: CY5-TGTACGACTGCAAACGCCAAAGTC- BHQ2 }\end{array}$ & $\begin{array}{l}\text { Nair et al., } \\
2019\end{array}$ \\
\hline
\end{tabular}


Direct hybridization assay use a labeled DNA probe complementary to the target sequence of a DNA or RNA molecule present in the target bacteria and quantify the DNA by correlation of signals measured from labels, labeled substrates, or subproducts (Lee et al., 2015; Mozola et al., 2013). The analytical detection technique used depends on the characteristics of the label (enzymatic, radioisotope, fluorescence, etc.), but colorimetric assays are the most common.

Laboratory automation and miniaturized tests may be important future complementary technologies, especially for rapid screening or identification purposes. Matrix-assisted laser desorption ionization-time of flight mass spectrometry (MALDI-TOF MS) allows ionization of biomolecules as DNA, proteins, peptides and sugars, compounds, which tend to be too fragile to be ionized by conventional MS. Used for bacterial identification, it mainly analyzes the composition of proteins of low molecular weight in cell lysate or whole cells, which means that, e.g., biomarker prefractionation, digestion, separation, or cleanup is not required. Main benefits of MALDI-TOF MS include reduced time for confirmation (1 hour) and reduced cost of identification and screening of multiple colonies at the same time. However, since it is still dependent on culture methods for isolation, it mainly serves as an identification tool. Studies applying MALDI-TOF-MS for salmonellae indicate that the method provides high accuracy in identification of salmonellae at species level, but currently is limited in capacity to type or subtype salmonellae serovars (Kang et al., 2017). It is suggested that MALDI-TOF MS can be used in conjunction with culture media and to some extent compensate for a lack of specificity of some culture media for salmonellae giving an overall cost effective and rapid test procedure when capital investments are made (Perry, 2017). Biosensors are analytical devices aiming to perform chemical or biological analysis theoretically with no considerable sample preprocessing and comprises a bio-receptor integrated with a signal transducer (Silva et al., 2018). Bio-receptors for pathogen detection recognize and react with enzymes, whole cells, specific proteins, antibodies or their fragments, nucleic acids or related substances and since read by a transduced signal easy to interpret. However, even though development is ongoing, the examples of commercial biosensors currently available in the market seem to be limited. 


\section{References}

Abbott, S.L., Portoni, B.A. and Janda, J.M. (1999). Urinary tract infections associated with nontyphoidal Salmonella serogroups. Journal of Clinical MicrobiologyJournal of Clinical Microbiology. 37, pp. 4177-4178.

Abd-Elall, A.M.M. and Maysa, A.I.A. (2015). Survival and growth behaviour of Salmonella enterica serovar Typhimurium in lettuce leaves and soil at various temperatures. International Food Research JournalInternational Food Research Journal. 22, pp. 1817-1823.

Abdel-Monem, M.H. and Dowidar, A. (1990). Recoveries of Salmonella from soil in Eastern region of Saudi Arabia Kingdom. The Journal of the Egyptian Public Health AssociationThe Journal of the Egyptian Public Health Association. 65, pp. 61-75.

Abulreesh, H.H., Annous, B. and Gurtler, J.B. (2012). Salmonellae in the Environment. Salmonella-Distribution, adaptation, control measures and molecular technologies. Intech Open. London, United Kingdom. pp. 19-50. doi: 10.5772/28201.

Adeolu, M., Alnajar, S., Naushad, S. and S. R, G. (2016). Genome-based phylogeny and taxonomy of the 'Enterobacteriales': proposal for Enterobacterales ord. nov. divided into the families Enterobacteriaceae, Erwiniaceae fam. nov., Pectobacteriaceae fam. nov., Yersiniaceae fam. nov., Hafniaceae fam. nov., Morgane. Int J Syst Evol MicrobiolInt J Syst Evol Microbiol. 2016/09/14 ed.66, pp. 5575-5599.

Ahmed, W., Vieritz, A., Goonetilleke, A. and Gardner, T. (2010). Health risk from the use of roof-harvested rainwater in Southeast Queensland, Australia, as potable or nonpotable water, determined using quantitative microbial risk assessment. Appl. Environ. Microbiol.Appl. Environ. Microbiol. 76, pp. 7382-7391.

Ahsan, S. and Rahman, S. (2018). Azithromycin Resistance in Clinical Isolates of Salmonella enterica Serovars Typhi and Paratyphi in Bangladesh. Microb Drug ResistMicrob Drug Resist. 2018/07/18 ed.

Alam, M.W. and Mohammad, Z. (2012). Occurrences of Salmonella spp. in water and soil sample of the Karnafuli river estuary. Microbes and HealthMicrobes and Health. 1, pp. 41-45.

Albihn, A. and Stenström, T.A. (1998). Systemanalys VA - Hygienstudie. (Systems analysis of sanitation systemsbiosecurity). VA - FORSK rapport 1998-16, Stockholm, SwedenVA - FORSK rapport 1998-16, Stockholm, Sweden.

Alikhan, N.F., Zhou, Z., Sergeant, M.J. and Achtman, M. (2018). A genomic overview of the population structure of Salmonella. PLoS GenetPLoS Genet. 2018/04/06 ed.14, pp. e1007261.

Allerberger, F.J., Dierich, M.P., Ebner, A., Keating, M.R., Steckelberg, J.M., Yu, P.K.W. et al. (1992). URINARY-TRACT INFECTION CAUSED BY NONTYPHOIDAL SALMONELLA - REPORT OF 30 CASES. Urologia InternationalisUrologia Internationalis. 48, pp. 395-400.

Alonso, J.L., Botella, M.S., Amorós, I. and Rambach, A. (1992). SALMONELLA DETECTION IN MARINE WATERS USING A SHORT STANDARD METHOD. Water ResearchWater research. 26, pp. 973-978.

Andrews, W.H., Jacobson, A. and Hammack, T. (2011). Chapter 5: Salmonella. Bacteriological Analytical Manual (BAM). U.S. Food and Drug Administration. Silver Spring, Maryland, USA.

Arrus, K.M., Holley, R.A., Ominski, K.H., Tenuta, M. and Blank, G. (2006). Influence of temperature on Salmonella survival in hog manure slurry and seasonal temperature profiles in farm manure storage reservoirs. Livestock ScienceLivestock Science. 102, pp. 226-236.

Azmatullah, A., Qamar, F.N., Thaver, D., Zaidi, A.K. and Bhutta, Z.A. (2015). Systematic review of the global epidemiology, clinical and laboratory profile of enteric fever. J Glob HealthJ Glob Health. 2015/12/10 ed.5, pp. 020407.

Bahadır, E.Burcu and Sezgintürk, M.Kemal (2016). Lateral flow assays: Principles, designs and labels. TrAC Trends in Analytical ChemistryTrAC Trends in Analytical Chemistry. 82, pp. 286-306. 
Bajracharya, D., Khan, M.I.,.,., Shrestha, P., Joshi, N., Upreti, S.R. et al. (2014). 25 years after Vi typhoid vaccine efficacy study, typhoid affects significant number of population in Nepal. PLoS OnePlos One. 2014/01/09 ed.9, pp. e77974.

Baker, S., Holt, K.E., Clements, A.C.A., Karkey, A., Arjyal, A., Boni, M.F. et al. (2011). Combined high-resolution genotyping and geospatial analysis reveals modes of endemic urban typhoid fever transmission. Open BiologyOpen Biology. 1, pp. 110008-110008.

Balaji, V., Kapil, A., Shastri, J., Pragasam, A.K., Gole, G., Choudhari, S. et al. (2018). Longitudinal Typhoid Fever Trends in India from 2000 to 2015. Am J Trop Med HygAm J Trop Med Hyg. 2018/07/27 ed.

Baloda, S.B., Christensen, L. and Trajcevska, S. (2001). Persistence of a Salmonella enterica serovar typhimurium DT12 clone in a piggery and in agricultural soil amended with Salmonella-contaminated slurry. Applied and Environmental MicrobiologyApplied and Environmental Microbiology. 67, pp. 2859-2862.

Baudart, J., Lemarchand, K., Brisabois, A. and Lebaron, P. (2000). Diversity of Salmonella strains isolated from the aquatic environment as determined by serotyping and amplification of the ribosomal DNA spacer regions. Applied and Environmental MicrobiologyApplied and Environmental Microbiology. 66, pp. 1544-1552.

Berry, E.D., Millner, P.D., Wells, J.E., Kalchayanand, N. and Guerini, M.N. (2013). Fate of Naturally Occurring Escherichia coli O157:H7 and Other Zoonotic Pathogens during Minimally Managed Bovine Feedlot Manure Composting Processes. Journal of Food ProtectionJournal of food protection. 76, pp. 1308-1321.

Bhutta, Z.A., Gaffey, M., Crump, J.A., Steele, D., Breiman, R.F., Mintz, E.D. et al. (2018). Typhoid Fever: Way Forward. Am J Trop Med HygAm J Trop Med Hyg. 2018/07/27 ed.

Bhutta, Z.A., Zaidi, A.K.M. and Pangestu, T. (2018). Reducing Typhoid Burden within a Generation. Am J Trop Med HygAm J Trop Med Hyg. 2018/07/27 ed.

Bischel, H.N., Schindelholz, S., Schoger, M., Decrey, L., Buckley, C.A., Udert, K.M. et al. (2016). Bacteria Inactivation during the Drying of Struvite Fertilizers Produced from Stored Urine. Environmental Science \&amp; TechnologyEnvironmental science \&amp; technologyEnviron Sci Technol. 50, pp. 13013-13023.

Bolton, D.J., Pearce, R., Sheridan, J.J., McDowell, D.A. and Blair, I.S. (2003). Decontamination of pork carcasses during scalding and the prevention of Salmonella cross-contamination. Journal of Applied MicrobiologyJournal of applied microbiologyJ Appl Microbiol. 94, pp. 1036-1042.

Brenner, F.W., Villar, R.G., Angulo, F.J., Tauxe, R. and Swaminathan, B. (2000). Salmonella nomenclature. J Clin MicrobiolJ Clin Microbiol. 2000/07/06 ed.38, pp. 2465-7.

Britto, C.D., Dyson, Z.A., Duchene, S., Carter, M.J., Gurung, M., Kelly, D.F. et al. (2018). Laboratory and molecular surveillance of paediatric typhoidal Salmonella in Nepal: Antimicrobial resistance and implications for vaccine policy. PLoS Negl Trop DisPLoS Negl Trop Dis. 2018/04/24 ed.12, pp. e0006408.

Britto, C., Pollard, A.J., Voysey, M. and Blohmke, C.J. (2017). An Appraisal of the Clinical Features of Pediatric Enteric Fever: Systematic Review and Meta-analysis of the Age-Stratified Disease Occurrence. Clin Infect DisClin Infect Dis. 2017/04/04 ed.64, pp. 1604-1611.

Burns, A.M., Duffy, G., Walsh, D., Tiwari, B.K., Grant, J., Lawlor, P.G. et al. (2016). Survival characteristics of monophasic Salmonella Typhimurium 4,[5],12:i:- strains derived from pig feed ingredients and compound feed. Food ControlFood ControlFood Control. 64, pp. 105-114.

Buzrul, S. and Alpas, H. (2007). Modeling inactivation kinetics of food borne pathogens at a constant temperature. LwtFood Science and TechnologyLwt-Food Science and TechnologyLwt-Food Science and Technology. 40, pp. 632-637.

Byappanahalli, M.N., Sawdey, R., Ishii, S., Shively, D.A., Ferguson, J.A., Whitman, R.L. et al. (2009). Seasonal stability of Cladophora-associated Salmonella in Lake Michigan watersheds. Water ResWater ResWater research. 2008/12/09 ed.43, pp. 806-14. 
.. (2017). Selected Analytical Methods for Environmental Remediation and Recovery (SAM) (EPA/600/R-17/356). U.S. Environmental Protection Agency, Washington, DC. U.S. Environmental Protection Agency, Washington, DC,.

Collaborators, G.B.D.Diar (2017). Estimates of global, regional, and national morbidity, mortality, and aetiologies of diarrhoeal diseases: a systematic analysis for the Global Burden of Disease Study 2015. Lancet Infect DisLancet Infect Dis. 2017/06/06 ed.17, pp. 909-948.

Cote, C., Masse, D.I. and Quessy, S. (2006). Reduction of indicator and pathogenic microorganisms by psychrophilic anaerobic digestion in swine slurries. Bioresource TechnologyBioresource Technology. 97, pp. 686-691.

Cote, C. and Quessy, S. (2005). Persistence of Escherichia coli and Salmonella in surface soil following application of liquid hog manure for production of pickling cucumbers. J Food ProtJ Food Prot. 68, pp. 900-5.

Cox, N.A., Cosby, D.E., Berrang, M.E., Richardson, K.E., Holcombe, N. and Weller, C. (2018). The effect of environmental poultry samples on the $\mathrm{pH}$ of typical Salmonella pre-enrichment and enrichment media following incubation. Journal of Applied Poultry ResearchJournal of Applied Poultry Research. 27, pp. 112-115.

Cuong, N. (2011). Typhoid vaccine used in Vietnam and its impact. Consultation on Typhoid Vaccine Introduction and Typhoid Surveillance. Available at: https://www. sabin. org/sites/sabin. org/files/CUONG\% 20Typhoid\% 20Vaccine\% 20in\% 20Vietnam. pdf. Accessed JuneConsultation on Typhoid Vaccine Introduction and Typhoid Su. 10, pp. 2018.

Dahab, M.F. and Surampalli, R.Y. (2002). Effects of aerobic and anaerobic digestion systems on pathogen and pathogen indicator reduction in municipal sludge. Water Sci TechnolWater Sci Technol. 2002/12/14 ed.46, pp. 181-7.

Danyluk, M.D., Nozawa-Inoue, M., Hristova, K.R., Scow, K.M., Lampinen, B. and Harris, L.J. (2008). Survival and growth of Salmonella Enteritidis PT 30 in almond orchard soils. Journal of Applied MicrobiologyJournal of applied microbiology. 104, pp. 1391-1399.

Darton, T.C., Jones, C., Blohmke, C.J., Waddington, C.S., Zhou, L., Peters, A. et al. (2016). Using a Human Challenge Model of Infection to Measure Vaccine Efficacy: A Randomised, Controlled Trial Comparing the Typhoid Vaccines M01ZH09 with Placebo and Ty21a. PLoS Negl Trop DisPLoS Negl Trop Dis. 2016/08/18 ed.10, pp. e0004926.

Das, J.K., Hasan, R., Zafar, A., Ahmed, I., Ikram, A., Nizamuddin, S. et al. (2018). Trends, Associations, and Antimicrobial Resistance of Salmonella Typhi and Paratyphi in Pakistan. Am J Trop Med HygAm J Trop Med Hyg. 2018/07/27 ed.

Date, K.A., Newton, A.E., Medalla, F., Blackstock, A., Richardson, L., McCullough, A. et al. (2016). Changing Patterns in Enteric Fever Incidence and Increasing Antibiotic Resistance of Enteric Fever Isolates in the United States, 2008-2012. Clin Infect DisClin Infect Dis. 2016/04/20 ed.63, pp. 322-9.

Davies, R.H. and Wray, C. (1996). Seasonal variations in the isolation of Salmonella typhimurium, Salmonella enteritidis, Bacillus cereus and Clostridium perfringens from environmental samples. Zentralblatt fur Veterinarmedizin. Reihe B. Journal of veterinary medicine. Series BZentralblatt fur Veterinarmedizin. Reihe B. Journal of veterinary medicine. Series B. 43 , pp. 119-27.

Dewettinck, T., Van Houtte, E., Geenens, D., Van Hege, K. and Verstraete, W. (2001). HACCP (Hazard Analysis and Critical Control Points) to guarantee safe water reuse and drinking water production-a case study. Water Science and TechnologyWater Science and Technology. 43, pp. 31-38.

Duffy, G., Ellison, A., Anderson, W., Cole, M.B. and Stewart, G.S.A.B. (1995). Use of Bioluminescence to Model the Thermal Inactivation of Salmonella-Typhimurium in the Presence of a Competitive Microflora. Applied and Environmental MicrobiologyApplied and Environmental MicrobiologyApplied and Environmental Microbiology. 61, pp. 3463-3465.

Eckner, K.F. (1992). Fluorometric Analysis of Alkaline-Phosphatase Inactivation Correlated to Salmonella and Listeria Inactivation. Journal of Food ProtectionJournal of food protection. 55, pp. 960-963.

.. (2012). Cross-contamination and recontamination by Salmonella in foods: A review. Food Research InternationalFood Research International. 45, pp. 545-556. 
Ellis, S., Tyrrel, S., O'Leary, E., Richards, K., Griffiths, B. and Ritz, K. (2018). Proportion of Sewage Sludge to Soil Influences the Survival of Salmonella Dublin and Escherichia coli. Clean-Soil Air WaterClean-Soil Air Water. 46,.

Elving, J., Ottoson, J.R., Vinneras, B. and Albihn, A. (2010). Growth potential of faecal bacteria in simulated psychrophilic/mesophilic zones during composting of organic waste. Journal of Applied MicrobiologyJournal of applied microbiologyJ Appl Microbiol. 108, pp. 1974-1981.

Elving, J., Vinneras, B., Albihn, A. and Ottoson, J.R. (2014). Thermal treatment for pathogen inactivation as a risk mitigation strategy for safe recycling of organic waste in agriculture. Journal of Environmental Science and Health Part BPesticides Food Contaminants and Agricultural WastesJournal of Environmental Science and Health Part B-Pesticides Food Contaminants and Agricultural WastesJournal of Environmental Science and Health Part . 49, pp. 679-689.

Eng, S.-.K., Pusparajah, P., Mutalib, N-S.Ab, Ser, H.-.L., Chan, K.-.G. and Lee, L.-.H. (2015). Salmonella: a review on pathogenesis, epidemiology and antibiotic resistance. Frontiers in Life ScienceFrontiers in Life Science. 8, pp. 284-293.

Erickson, M.C., Islam, M., Sheppard, C., Liao, J. and Doyle, M.P. (2004). Reduction of Escherichia coli 0157 : H7 and Salmonella enterica serovar enteritidis in chicken manure by larvae of the black soldier fly. Journal of Food ProtectionJournal of food protection. 67, pp. 685-690.

Erickson, M.C., Liao, J., Ma, L., Jiang, X. and Doyle, M.P. (2014). Thermal and Nonthermal Factors Affecting Survival of Salmonella and Listeria monocytogenes in Animal Manure-Based Compost Mixtures. Journal of Food ProtectionJournal of food protection. 77, pp. 1512-1518.

Feasey, N.A., Masesa, C., Jassi, C., Faragher, E.B., Mallewa, J., Mallewa, M. et al. (2015). Three Epidemics of Invasive Multidrug-Resistant Salmonella Bloodstream Infection in Blantyre, Malawi, 1998-2014. Clin Infect DisClin Infect Dis. 2015/10/10 ed.61 Suppl 4, pp. S363-71.

Gal-Mor, O., Boyle, E.C. and Grassl, G.A. (2014). Same species, different diseases: how and why typhoidal and nontyphoidal Salmonella enterica serovars differ. Frontiers in microbiologyFrontiers in microbiology. 5, pp. 391.

Gannon, V.P., Graham, T.A., Read, S., Ziebell, K., Muckle, A., Mori, J. et al. (2004). Bacterial pathogens in rural water supplies in Southern Alberta, Canada. J Toxicol Environ Health AJ Toxicol Environ Health A. 67, pp. 1643-53.

Garcia, R., Baelum, J., Fredslund, L., Santorum, P. and Jacobsen, C.S. (2010). Influence of Temperature and Predation on Survival of Salmonella enterica Serovar Typhimurium and Expression of invA in Soil and Manure-Amended Soil. Applied and Environmental MicrobiologyApplied and Environmental Microbiology. 76, pp. 5025-5031.

Gauld, J.S., Olgemoeller, F., Nkata, R., Li, C., Chirambo, A., Morse, T. et al. (2019). Domestic river water use and risk of typhoid fever: results from a case-control study in Blantyre, Malawi. Clinical Infectious DiseasesClinical Infectious Diseases. pp. 1-25.

George, S.M., Richardson, L.C.C., Pol, I.E. and Peck, M.W. (1998). Effect of oxygen concentration and redox potential on recovery of sublethally heat-damaged cells of Escherichia coli 0157 : H7, Salmonella enteritidis and Listeria monocytogenes. Journal of Applied MicrobiologyJournal of applied microbiologyJ Appl Microbiol. 84, pp. 903-909.

Gerba, C.P., N. del Campo, C.-., Brooks, J.P. and Pepper, I.L. (2008). Exposure and risk assessment of Salmonella in recycled residuals. Water Sci TechnolWater Sci Technol. 57, pp. 1061-5.

Gibney, K.B., O'Toole, J., Sinclair, M. and Leder, K. (2017). Burden of Disease Attributed to Waterborne Transmission of Selected Enteric Pathogens, Australia, 2010. Am J Trop Med HygAm J Trop Med Hyg. 2017/07/19 ed.96, pp. 1400-1403.

Gopinath, S., Carden, S. and Monack, D. (2012). Shedding light on Salmonella carriers. Trends MicrobiolTrends Microbiol. 2012/05/18 ed.20, pp. 320-7.

Gopo, J.M. and Chingobe, N. (1995). SALMONELLA CONTAMINATION OF RECYCLED EFFLUENT OF TREATED SEWAGE AND URBAN WASTE-WATER. Water SaWater Sa. 21, pp. 245-250.

Gordon, M.A. (2011). Invasive nontyphoidal Salmonella disease: epidemiology, pathogenesis and diagnosis. Curr Opin 
Infect DisCurr Opin Infect Dis. 2011/08/17 ed.24, pp. 484-9.

Graziani, C., Losasso, C., Luzzi, I., Ricci, A., Scavia, G. and Pasquali, P. (2017). Chapter 5 - Salmonella. Foodborne Diseases (Third Edition). (Dodd, C.E.R., Aldsworth, T., Stein, R.A., Cliver, D.O. and Riemann, H.P., ed.). Academic Press. pp. 133-169.

Haddock, R.L. and Nocon, F.A. (1993). THE SOURCE OF SALMONELLA CONTAMINATION OF SOIL ON GUAM. Journal of Environmental HealthJournal of Environmental Health. 55, pp. 17-17.

Haddock, R.L. and Nocon, F.A. (1986). SALMONELLA CONTAMINATION OF SOIL IN CHILDRENS PLAY AREAS ON GUAM. Journal of Environmental HealthJournal of Environmental Health. 49, pp. 158-160.

Haselbeck, A.H., Panzner, U., Im, J., Baker, S., Meyer, C.G. and Marks, F. (2017). Current perspectives on invasive nontyphoidal Salmonella disease. Curr Opin Infect DisCurr Opin Infect Dis. 2017/07/22 ed.30, pp. 498-503.

Haug, R.T. (1993). <> practical handbook of compost engineering. Lewis Publishers. Boca Raton etc. pp. 717 S.

Hendriksen, R.S., Vieira, A.R., Karlsmose, S., Wong, D.M.Lo Fo, Jensen, A.B., Wegener, H.C. et al. (2011). Global monitoring of Salmonella serovar distribution from the World Health Organization Global Foodborne Infections Network Country Data Bank: results of quality assured laboratories from 2001 to 2007. Foodborne Pathog DisFoodborne Pathog Dis. 2011/04/16 ed.8, pp. 887-900.

Hildebrandt, I.M., Marks, B.P., Juneja, V.K., Osoria, M., Hall, N.O. and Ryser, E.T. (2016). Cross-Laboratory Comparative Study of the Impact of Experimental and Regression Methodologies on Salmonella Thermal Inactivation Parameters in Ground Beef. Journal of Food ProtectionJournal of food protection. 79, pp. 1097-1106.

Hiyoshi, H., Tiffany, C.R., Bronner, D.N. and Baumler, A.J. (2018). Typhoidal Salmonella serovars: ecological opportunity and the evolution of a new pathovar. FEMS Microbiol RevFEMS Microbiol Rev. 2018/05/24 ed.42, pp. 527-541.

Hohmann, E.L. (2001). Nontyphoidal salmonellosis. Clin Infect DisClin Infect Dis. 2001/02/15 ed.32, pp. 263-9.

Howard, I., Espigares, E., Lardelli, P., Martin, J.L. and Espigares, M. (2004). Evaluation of microbiological and physicochemical indicators for wastewater treatment. Environ ToxicolEnviron ToxicolEnviron Toxicol. 2004/04/22 ed.19, pp. 241-9.

Hruby, C.E., Soupir, M.L., Moorman, T.B., Pederson, C. and Kanwar, R. (2018). Salmonella and Fecal Indicator Bacteria Survival in Soils Amended with Poultry Manure. Water Air and Soil PollutionWater Air and Soil Pollution. 229,.

Humpheson, L., Adams, M.R., Anderson, W.A. and Cole, M.B. (1998). Biphasic thermal inactivation kinetics in Salmonella enteritidis PT4. Applied and Environmental MicrobiologyApplied and Environmental MicrobiologyApplied and Environmental Microbiology. 64, pp. 459-464.

Humphrey, T. (2000). Public-health aspects of Salmonella infection. Salmonella in domestic animals, CABI Publishing.

Huss, A.R., Fuller, J.C., Centrella, W., Marshall, D.L., Deliephan, A. and Jones, C.K. (2017). Mitigation of Salmonella on Pet Food Kibbles by Using Liquid and Powdered 3-Hydroxy-3-Methylbutyric Acid. Journal of Food ProtectionJournal of food protection. 80, pp. 1080-1084.

Hutchison, M.L., Walters, L.D., Avery, S.M., Synge, B.A. and Moore, A. (2004). Levels of zoonotic agents in British livestock manures. Letters in Applied MicrobiologyLetters in Applied Microbiology. 39, pp. 207-214.

Islam, M., Morgan, J., Doyle, M.P., Phatak, S.C., Millner, P. and Jiang, X. (2004). Fate of Salmonella enterica serovar Typhimurium on carrots and radishes grown in fields treated with contaminated manure composts or irrigation water. Appl Environ MicrobiolAppl Environ Microbiol. 2004/04/07 ed.70, pp. 2497-502.

ISO (2017). ISO 6579-1:2017 Microbiology of the food chain - Horizontal method for the detection, enumeration and serotyping of Salmonella - Part 1: Detection of Salmonella spp. International Organization for Standardization. Geneva, Switzerland. 
ISO (2010). ISO 2010:19250 Water quality -- Detection of Salmonella spp. International Organization for Standardization (ISO). Geneva Switzerland.

Issenhuth-Jeanjean, S., Roggentin, P., Mikoleit, M., Guibourdenche, M., de Pinna, E., Nair, S. et al. (2014). Supplement 2008-2010 (no. 48) to the White-Kauffmann-Le Minor scheme. Res MicrobiolRes Microbiol. 2014/07/23 ed.165, pp. 526-30.

Jacobsen, C.S. and Bech, T.B. (2012). Soil survival of Salmonella and transfer to freshwater and fresh produce. Food Research InternationalFood Research International. 45, pp. 557-566.

Jarvis, N.A., O'Bryan, C.A., Dawoud, T.M., Park, S.H., Kwon, Y.M., Crandall, P.G. et al. (2016). An overview of Salmonella thermal destruction during food processing and preparation. Food ControlFood ControlFood Control. 68, pp. 280-290.

Jenkins, M.B., Endale, D.M. and Fisher, D.S. (2008). Most probable number methodology for quantifying dilute concentrations and fluxes of Salmonella in surface waters. J Appl Microbiolj Appl Microbiol. 104, pp. 1562-8.

Jimínez, B., Maya, C., Sanchez, E., Romero, A., Lira, L. and Barrios, J.A. (2002). Comparison of the quantity and quality of the microbiological content of sludge in countries with low and high content of pathogens. Water Science and Technology. 46, pp. 17-24.

Jimenez, B., Austin, A., Cloete, E. and Phasha, C. (2006). Using Ecosan sludge for crop production. Water Science and TechnologyWater Science and Technology. 54, pp. 169-177.

Jimenez, B., Austin, A., Cloete, E., Phasha, C. and Beltran, N. (2007). Biological risks to food crops fertilized with Ecosan sludge. Water Science and TechnologyWater Science and Technology. 55, pp. 21-9.

Jin, C., Gibani, M.M., Moore, M., Juel, H.B., Jones, E., Meiring, J. et al. (2017). Efficacy and immunogenicity of a Vi-tetanus toxoid conjugate vaccine in the prevention of typhoid fever using a controlled human infection model of Salmonella Typhi: a randomised controlled, phase $2 b$ trial. LancetLancet. 2017/10/03 ed.390, pp. 2472-2480.

Jin, T., Zhang, H., Boyd, G. and Tang, J. (2008). Thermal resistance of Salmonella enteritidis and Escherichia coli K12 in liquid egg determined by thermal-death-time disks. Journal of Food EngineeringJournal of Food EngineeringJournal of Food Engineering. 84, pp. 608-614.

John, J., Van Aart, C.J. and Grassly, N.C. (2016). The Burden of Typhoid and Paratyphoid in India: Systematic Review and Meta-analysis. PLoS Negl Trop DisPLoS Negl Trop Dis. 2016/04/16 ed.10, pp. e0004616.

Johnson, D.I. (2018). Bacterial Pathogenesis and their Virulence Factors. Springer International Publishing.

Jokinen, C.C., Schreier, H., Mauro, W., Taboada, E., Isaac-Renton, J.L., Topp, E. et al. (2010). The occurrence and sources of Campylobacter spp., Salmonella enterica and Escherichia coli 0157:H7 in the Salmon River, British Columbia, Canada. J Water HealthJ Water Health. 8, pp. 374-86.

Juneja, V.K. (2007). Thermal inactivation of Salmonella spp. in ground chicken breast or thigh meat. International Journal of Food Science and TechnologyInternational Journal of Food Science and TechnologyInternational Journal of Food Science and Technology. 42, pp. 1443-1448.

Juneja, V.K. and Marks, H.M. (2006). Growth kinetics of Salmonella spp. pre- and post-thermal treatment. International Journal of Food MicrobiologyInternational journal of food microbiologyInt J Food Microbiol. 109, pp. 54-59.

Jyoti, A., Ram, S., Vajpayee, P., Singh, G., Dwivedi, P.D., Jain, S.K. et al. (2010). Contamination of surface and potable water in South Asia by Salmonellae: culture-independent quantification with molecular beacon real-time PCR. Sci Total EnvironSci Total Environ. 408, pp. 1256-63.

Jyoti, A., Vajpayee, P., Singh, G., Patel, C.Bali, Gupta, K.Chand and Shanker, R. (2011). Identification of Environmental Reservoirs of Nontyphoidal Salmonellosis: Aptamer-Assisted Bioconcentration and Subsequent Detection of Salmonella Typhimurium by Quantitative Polymerase Chain Reaction. Environmental Science \&amp; TechnologyEnvironmental science \&amp; technology. 45, American Chemical Society. pp. 8996-9002. 
Kacprzak, M., Fijalkowski, K., Grobelak, A., Rosikon, K. and Rorat, A. (2015). Escherichia coli and Salmonella spp. Early Diagnosis and Seasonal Monitoring in the Sewage Treatment Process by EMA-qPCR Method. Polish Journal of MicrobiologyPolish Journal of Microbiology. 64, pp. 143-148.

Kariuki, S. and Onsare, R.S. (2015). Epidemiology and Genomics of Invasive Nontyphoidal Salmonella Infections in Kenya. Clin Infect DisClin Infect Dis. 2015/10/10 ed.61 Suppl 4, pp. S317-24.

Karkey, A., Jombart, T., Walker, A.W., Thompson, C.N., Torres, A., Dongol, S. et al. (2016). The ecological dynamics of fecal contamination and Salmonella Typhi and Salmonella Paratyphi A in municipal Kathmandu drinking water. PLoS neglected tropical diseasesPLoS neglected tropical diseases. 10, pp. e0004346.

Keddy, K.H., Smith, A.M., Sooka, A., Tau, N.P., Ngomane, H.M.P., Radhakrishnan, A. et al. (2018). The Burden of Typhoid Fever in South Africa: The Potential Impact of Selected Interventions. Am J Trop Med HygAm J Trop Med Hyg. 2018/07/27 ed.

Keddy, K.H., Sooka, A., Musekiwa, A., Smith, A.M., Ismail, H., Tau, N.P. et al. (2015). Clinical and Microbiological Features of Salmonella Meningitis in a South African Population, 2003-2013. Clin Infect DisClin Infect Dis. 2015/10/10 ed.61 Suppl 4, pp. S272-82.

Keddy, K.H., Takuva, S., Musekiwa, A., Puren, A.J., Sooka, A., Karstaedt, A. et al. (2017). An association between decreasing incidence of invasive non-typhoidal salmonellosis and increased use of antiretroviral therapy, Gauteng Province, South Africa, 2003-2013. PLoS OnePlos One. 2017/03/07 ed.12, pp. e0173091.

Khan, M.I., Soofi, S.B., Ochiai, R.L., Habib, M.A., Sahito, S.M., Nizami, S.Q. et al. (2012). Effectiveness of Vi capsular polysaccharide typhoid vaccine among children: a cluster randomized trial in Karachi, Pakistan. VaccineVaccine. 2012/06/23 ed.30, pp. 5389-95.

Kim, J., Diao, J.S., Shepherd, M.W., Singh, R., Heringa, S.D., Gong, C. et al. (2012). Validating Thermal Inactivation of Salmonella spp. in Fresh and Aged Chicken Litter. Applied and Environmental MicrobiologyApplied and Environmental MicrobiologyApplied and Environmental Microbiology. 78, pp. 1302-1307.

Kinde, H., Adelson, M., Ardans, A., Little, E.H., Willoughby, D., Berchtold, D. et al. (1997). Prevalence of Salmonella in municipal sewage treatment plant effluents in southern California. Avian DiseasesAvian Diseases. 41, pp. 392-398.

Kingsley, R.A. and Baumler, A.J. (2000). Host adaptation and the emergence of infectious disease: the Salmonella paradigm. Mol MicrobiolMol Microbiol. 2000/06/09 ed.36, pp. 1006-14.

Kirk, M.D., Pires, S.M., Black, R.E., Caipo, M., Crump, J.A., Devleesschauwer, B. et al. (2015). World Health Organization Estimates of the Global and Regional Disease Burden of 22 Foodborne Bacterial, Protozoal, and Viral Diseases, 2010: A Data Synthesis. PLoS MedPLoS Med. 2015/12/04 ed.12, pp. e1001921.

Klein, M., Brown, L., Tucker, R.W., Ashbolt, N.J., Stuetz, R.M. and Roser, D.J. (2010). Diversity and abundance of zoonotic pathogens and indicators in manures of feedlot cattle in Australia. Appl. Environ. Microbiol.Appl. Environ. Microbiol. 76, pp. 6947-6950.

Klemm, E.J., Shakoor, S., Page, A.J., Qamar, F.N., Judge, K., Saeed, D.K. et al. (2018). Emergence of an Extensively DrugResistant Salmonella enterica Serovar Typhi Clone Harboring a Promiscuous Plasmid Encoding Resistance to Fluoroquinolones and Third-Generation Cephalosporins. MBioMBio. 2018/02/22 ed.9,.

Krzyzanowski, Jr., F., Zappelini, L., Martone-Rocha, S., Dropa, M., Matte, M.Helena, Nacache, F. et al. (2014). Quantification and characterization of Salmonella spp. isolates in sewage sludge with potential usage in agriculture. Bmc MicrobiologyBmc Microbiology. 14,.

Kumar, A. and Kumar, S. (2003). Survival kinetics of Salmonella enterica serotype senftenberg (S-senftenberg) after heat and acid stress. World Journal of Microbiology \&amp; BiotechnologyWorld Journal of Microbiology \&amp; BiotechnologyWorld Journal of Microbiology \&amp; Biotechnology. 19, pp. 985-987.

Kumwenda, S., Msefula, C., Kadewa, W., Ngwira, B. and Morse, T. (2017). Estimating the Health Risk Associated with the Use of Ecological Sanitation Toilets in Malawi. Journal of environmental and public healthJournal of environmental and 
public health. 2017, pp. 3931802-3931802.

Lalander, C., Diener, S., Magri, M.E., Zurbrügg, C., Lindstrom, A. and Vinneras, B. (2013). Faecal sludge management with the larvae of the black soldier fly (Hermetia illucens) - From a hygiene aspect. Science of the Total EnvironmentScience of the total environmentSci Total Environ. 458, pp. 312-318.

Lalander, C., Diener, S., Zurbrügg, C. and Vinneras, B. (2019). Effects of feedstock on larval development and process efficiency in waste treatment with black soldier fly (Hermetia illucens). Journal of Cleaner ProductionJournal of Cleaner Production. 208, pp. 211-219.

Lalander, C.H., Komakech, A.J. and Vinneras, B. (2015). Vermicomposting as manure management strategy for urban small-holder animal farms - Kampala case study. Waste ManagementWaste ManagementWaste Management. 39, pp. 96-103.

Lamas, A., Miranda, J.M., Regal, P., Vazquez, B., Franco, C.M. and Cepeda, A. (2018). A comprehensive review of nonenterica subspecies of Salmonella enterica. Microbiol ResMicrobiol Res. 2017/11/18 ed.206, pp. 60-73.

Lang, N.L. and Smith, S.R. (2008). Time and temperature inactivation kinetics of enteric bacteria relevant to sewage sludge treatment processes for agricultural use. Water ResearchWater researchWater Res. 42, pp. 2229-2241.

Lee, K.-.M., Runyon, M., Herrman, T.J., Phillips, R. and Hsieh, J. (2015). Review of Salmonella detection and identification methods: Aspects of rapid emergency response and food safety. Food ControlFood Control. 47, pp. 264-276.

Levantesi, C., Bonadonna, L., Briancesco, R., Grohmann, E., Toze, S. and Tandoi, V. (2012). Salmonella in surface and drinking water: occurrence and water-mediated transmission. Food Research InternationalFood Research International. 45, pp. 587-602.

Levine, M.M., Ferreccio, C., Abrego, P., Martin, O.S., Ortiz, E. and Cryz, S. (1999). Duration of efficacy of Ty21a, attenuated Salmonella typhi live oral vaccine. VaccineVaccine. 1999/10/03 ed.17 Suppl 2, pp. S22-7.

Lianou, A. and Koutsoumanis, K.P. (2013). Evaluation of the strain variability of Salmonella enterica acid and heat resistance. Food MicrobiologyFood Microbiology. 34, pp. 259-267.

Liu, H.L., Whitehouse, C.A. and Lis, B.G. (2018). Presence and Persistence of Salmonella in Water: The Impact on Microbial Quality of Water and Food Safety. Frontiers in Public HealthFrontiers in Public Health. 6,.

Loewen, P.C. and Hengge-Aronis, R. (1994). The role of the sigma factor sigma S (KatF) in bacterial global regulation. Annu Rev MicrobiolAnnu Rev Microbiol. 1994/01/01 ed.48, pp. 53-80.

Luby, S.P. (2018). Urban Slums: A Supportive Ecosystem for Typhoidal Salmonellae. J Infect DisJ Infect Dis. 2018/07/31 ed.

Lynch, H., Arguello, H., Walia, K., Lawlor, P.G., Duffy, G., Gardiner, G.E. et al. (2017). Evaluation of an Alternative Experimental Infection Method, Which Closely Mimics the Natural Route of Transmission of Monophasic Salmonella Typhimurium in Pigs. Foodborne Pathogens and DiseaseFoodborne Pathogens and Disease. 14, pp. 23-28.

MacKenzie, K.D., Wang, Y., Musicha, P., Hansen, E.G., Palmer, M.B., Herman, D.J. et al. (2019). Parallel evolution leading to impaired biofilm formation in invasive Salmonella strains. PLoS geneticsPLoS genetics. 15, pp. e1008233.

Mai, N.L., Phan, V.B., Vo, A.H., Tran, C.T., Lin, F.Y., Bryla, D.A. et al. (2003). Persistent efficacy of Vi conjugate vaccine against typhoid fever in young children. N Engl J MedN Engl J Med. 2003/10/03 ed.349, pp. 1390-1.

Ma, L., Zhang, G.D., Gerner-Smidt, P., Mantripragada, V., Ezeoke, I. and Doyle, M.P. (2009). Thermal Inactivation of Salmonella in Peanut Butter. Journal of Food ProtectionJournal of food protection. 72, pp. 1596-1601.

Manas, P., Pagan, R., Raso, J. and Condon, S. (2003). Predicting thermal inactivation in media of different pH of Salmonella grown at different temperatures. International Journal of Food MicrobiologyInternational journal of food microbiologyInt J Food Microbiol. 87, pp. 45-53. 
Marco, C., Delgado, I., Vargas, C., Munoz, X., Bhutta, Z.A. and Ferreccio, C. (2018). Typhoid Fever in Chile 1969-2012: Analysis of an Epidemic and Its Control. Am J Trop Med HygAm J Trop Med Hyg. 2018/07/27 ed.

Marks, F., von Kalckreuth, V., Aaby, P., Adu-Sarkodie, Y., Tayeb, M.Ahmed El, Ali, M. et al. (2017). Incidence of invasive salmonella disease in sub-Saharan Africa: a multicentre population-based surveillance study. The Lancet Global HealthThe Lancet Global Health. 5, pp. e310-e323.

Marzel, A., Desai, P.T., Goren, A., Schorr, Y.I., Nissan, I., Porwollik, S. et al. (2016). Persistent Infections by Nontyphoidal Salmonella in Humans: Epidemiology and Genetics. Clin Infect DisClin Infect Dis. 2016/01/08 ed.62, pp. 879-886.

Mazzotta, A.S. (2000). D- and z-values of Salmonella in ground chicken breast meat. Journal of Food SafetyJournal of Food SafetyJournal of Food Safety. 20, pp. 217-223.

Meinersmann, R.J., Berrang, M.E., Jackson, C.R., Fedorka-Cray, P., Ladely, S., Little, E. et al. (2008). Salmonella, Campylobacter and Enterococcus spp.: their antimicrobial resistance profiles and their spatial relationships in a synoptic study of the Upper Oconee River basin. Microb EcolMicrob Ecol. 55, pp. 444-52.

Mermin, J.H., Villar, R., Carpenter, J., Roberts, L., Samaridden, A., Gasanova, L. et al. (1999). A massive epidemic of multidrug-resistant typhoid fever in Tajikistan associated with consumption of municipal water. J Infect DisJ Infect Dis. 1999/05/06 ed.179, pp. 1416-22.

Miller, C., Heringa, S., Kim, J. and Jiang, X.P. (2013). Analyzing Indicator Microorganisms, Antibiotic Resistant Escherichia coli, and Regrowth Potential of Foodborne Pathogens in Various Organic Fertilizers. Foodborne Pathogens and DiseaseFoodborne Pathogens and DiseaseFoodborne Pathog Dis. 10, pp. 520-527.

Monack, D.M. (2012). Salmonella persistence and transmission strategies. Curr Opin MicrobiolCurr Opin Microbiol. 2011/12/06 ed.15, pp. 100-7.

Monfort, S., Gayan, E., Condon, S., Raso, J. and Alvarez, I. (2011). Design of a combined process for the inactivation of Salmonella Enteritidis in liquid whole egg at 55 degrees C. International Journal of Food MicrobiologyInternational journal of food microbiologyInt J Food Microbiol. 145, pp. 476-482.

Mooijman, K.A. (2012). Culture Media for the Isolation of Salmonella. Handbook of Culture Media for Food and Water Microbiology, 3rd Edition. (Corry, J.E.L., Curtis, G.D.W. and Baird, R.M., ed.). Royal Soc Chemistry. Cambridge. pp. 261-286.

Mumcuoglu, K.Y., Miller, J., Mumcuoglu, M., Friger, M. and Tarshis, M. (2001). Destruction of bacteria in the digestive tract of the maggot of Lucilia sericata (Diptera : Calliphoridae). Journal of Medical EntomologyJournal of Medical EntomologyJournal of Medical Entomology. 38, pp. 161-166.

Murphy, R.Y., Duncan, L.K., Beard, B.L. and Driscoll, K.H. (2003). And z values of Salmonella, Listeria innocua, and Listeria monocytogenes in fully cooked poultry products. Journal of Food ScienceJ Food Sci. 68, pp. 1443-1447.

Murphy, R.Y., Marks, B.P., Johnson, E.R. and Johnson, M.G. (2000). Thermal inactivation kinetics of Salmonella and Listeria in ground chicken breast meat and liquid medium. Journal of Food ScienceJ Food Sci. 65, pp. 706-710.

Murphy, R.Y., Marks, B.P., Johnson, E.R. and Johnson, M.G. (1999). Inactivation of Salmonella and Listeria in ground chicken breast meat during thermal processing. Journal of Food ProtectionJournal of food protection. 62, pp. 980-985.

Muthumbi, E., Morpeth, S.C., Ooko, M., Mwanzu, A., Mwarumba, S., Mturi, N. et al. (2015). Invasive Salmonellosis in Kilifi, Kenya. Clin Infect DisClin Infect Dis. 2015/10/10 ed.61 Suppl 4, pp. S290-301.

Mutsakatira, E., Buckley, C. and Mercer, S.J. (2018). Potential use of the black soldier fly larvae in faecal sludge management: a study in Durban, South Africa. ransformation towards sustainable and resilient WASH services: Proceedings of the 41st WEDC International Conference. (Shaw, R.J., ed.). WEDC, Loughborough University. Nakuru, Kenya. pp. 8.

Naheed, A., Ram, P.K., Brooks, W.A., Hossain, M.A., Parsons, M.B., Talukder, K.A. et al. (2010). Burden of typhoid and 
paratyphoid fever in a densely populated urban community, Dhaka, Bangladesh. Int J Infect DisInt J Infect Dis. 2010/03/20 ed.14 Suppl 3, pp. e93-9.

Nga, T.V.T., Duy, P.T., Lan, N.P.H., Chau, N.V.V. and Baker, S. (2018). The Control of Typhoid Fever in Vietnam. Am J Trop Med HygAm J Trop Med Hyg. 2018/07/27 ed.

Nga, T.Vu Thieu, Parry, C.M., Le, T., Lan, N.Phu Huong, Diep, T.Song, Campbell, J.I. et al. (2012). The decline of typhoid and the rise of non-typhoid salmonellae and fungal infections in a changing HIV landscape: bloodstream infection trends over 15 years in southern Vietnam. Transactions of the Royal Society of Tropical Medicine and HygieneTransactions of the Royal Society of Tropical Medicine and Hygiene. 106, pp. 26-34.

Nicholson, F.A., Groves, S.J. and Chambers, B.J. (2005). Pathogen survival during livestock manure storage and following land application. Bioresource TechnologyBioresource Technology. 96, pp. 135-143.

Nordin, A., Göttert, D. and Vinneras, B. (2018). Decentralised black water treatment by combined auto-thermal aerobic digestion and ammonia - A pilot study optimising treatment capacity. Journal of Environmental ManagementJournal of Environmental Management. 207, pp. 313-318.

Nordin, A.C. and Vinneras, B. (2015). Sanitising black water by auto-thermal aerobic digestion (ATAD) combined with ammonia treatment. Water Sci TechnolWater Sci Technol. 2015/12/18 ed.72, pp. 2112-21.

Obaro, S.K., Hassan-Hanga, F., Olateju, E.K., Umoru, D., Lawson, L., Olanipekun, G. et al. (2015). Salmonella Bacteremia Among Children in Central and Northwest Nigeria, 2008-2015. Clin Infect DisClin Infect Dis. 2015/10/10 ed.61 Suppl 4, pp. S325-31.

R Ochiai, L., Acosta, C.J., Danovaro-Holliday, M., Baiqing, D., Bhattacharya, S.K., Agtini, M.D. et al. (2008). A study of typhoid fever in five Asian countries: disease burden and implications for controls. Bulletin of the world health organizationBulletin of the world health organization. 86, pp. 260-268.

Odjadjare, E.C. and Olaniran, A.O. (2015). Prevalence of Antimicrobial Resistant and Virulent Salmonella spp. in Treated Effluent and Receiving Aquatic Milieu of Wastewater Treatment Plants in Durban, South Africa. Int J Environ Res Public HealthInt J Environ Res Public HealthInternational journal of environmental research and public health. 2015/08/22 ed.12, pp. 9692-713.

Olsen, J.E. and Larsen, H.E. (1987). Bacterial Decimation Times in Anaerobic Digestions of Animal Slurries. Biological WastesBiological WastesBiological Wastes. 21, pp. 153-168.

Ongeng, D., Geeraerd, A.Hellena, Springael, D., Ryckeboer, J., Muyanja, C. and Mauriello, G. (2015). Fate of Escherichia coli 0157:H7 and Salmonella enterica in the manure-amended soil-plant ecosystem of fresh vegetable crops: A review. Critical Reviews in MicrobiologyCritical Reviews in Microbiology. 41, pp. 273-294.

OrtaRamirez, A., Price, J.F., Hsu, Y.C., Veeramuthu, G.J., CherryMerritt, J.S. and Smith, D.M. (1997). Thermal inactivation of Escherichia coli 0157:H7, Salmonella senftenberg, and enzymes with potential as time-temperature indicators in ground beef. Journal of Food ProtectionJournal of food protection. 60, pp. 471-475.

Osaili, T.M., Griffis, C.L., Martin, E.M., Beard, B.L., Keener, A.E. and Marcy, J.A. (2007). Thermal inactivation of Escherichia coli 0157 : H7, Salmonella, and Listeria monocytogenes in breaded pork patties. Journal of Food ScienceJ Food Sci. 72, pp. M56-M61.

Ottoson, J., Nordin, A., von Rosen, D. and Vinneras, B. (2008). Salmonella reduction in manure by the addition of urea and ammonia. Bioresource TechnologyBioresource Technology. 99, pp. 1610-1615.

Padan, E., Bibi, E., Ito, M. and Krulwich, T.A. (2005). Alkaline pH homeostasis in bacteria: New insights. Biochimica et Biophysica Acta (BBA) - BiomembranesBiochimica et Biophysica Acta (BBA) - Biomembranes. 1717, pp. 67-88.

Paluszak, Z., Ligocka, A., Breza-Boruta, B. and Olszewska, H. (2003). The survival of selected fecal bacteria in peat soil amended with slurry. 6 , 
Parmar, N., Singh, A. and Ward, O.P. (2001). Characterization of the combined effects of enzyme, pH and temperature treatments for removal of pathogens from sewage sludge. World Journal of Microbiology and BiotechnologyWorld Journal of Microbiology and Biotechnology. 17, pp. 169-172.

Patchanee, P., Molla, B., White, N., Line, D.E. and Gebreyes, W.A. (2010). Tracking salmonella contamination in various watersheds and phenotypic and genotypic diversity. Foodborne Pathog DisFoodborne Pathog Dis. 7, pp. 1113-20.

Paterson, D.L., Harrison, M.W. and Robson, J.M. (1997). Clinical spectrum of urinary tract infections due to nontyphoidal Salmonella species. Clin Infect DisClin Infect Dis. 1997/10/06 ed.25, pp. 754.

,. (2010). Salmonella species, Including Salmonella Typhi. 7th ed.

Pepper, I.L., Josephson, K.L., Bailey, R.L., Burr, M.D. and Gerba, C.P. (1993). Survival of indicator organisms in Sonoran Desert soil amended with sewage sludge. Journal of Environmental Science and Health - Part A Environmental Science and EngineeringJournal of Environmental Science and Health - Part A Environmental Science and Engineering. 28, pp. 1287-1302.

Phan, T.P., Khai, L.T.L., Loc, C.B., Hayashidani, H., Sameshima, T., Watanabe, T. et al. (2003). Isolation of Salmonella strains from the aquatic environment and comparison with those of animal origin in Tan Phu Thanh Village, Mekong Delta, Vietnam. Jarq-Japan Agricultural Research QuarterlyJarq-Japan Agricultural Research Quarterly. 37, pp. $237-241$.

T. Phuong, L.Thi, Rattanavong, S., Vongsouvath, M., Davong, V., N. Lan, P.Huong, Campbell, J.I. et al. (2017). Nontyphoidal Salmonella serovars associated with invasive and non-invasive disease in the Lao People's Democratic Republic. Trans R Soc Trop Med HygTrans R Soc Trop Med Hyg. 2018/01/18 ed.111, pp. 418-424.

Pin, C., Hansen, T., Munoz-Cuevas, M., de Jonge, R., Rosenkrantz, J.T., Lofstrom, C. et al. (2012). The Transcriptional Heat Shock Response of Salmonella Typhimurium Shows Hysteresis and Heated Cells Show Increased Resistance to Heat and Acid Stress. Plos OnePlos OnePlos One. 7,.

Popoff, M.Y., Bockemuhl, J. and Gheesling, L.L. (2004). Supplement 2002 (no. 46) to the Kauffmann-White scheme. Res MicrobiolRes Microbiol. 2004/08/18 ed.155, pp. 568-70.

Pourcher, A.M., Morand, P., Picard-Bonnaud, F., Billaudel, S., Monpoeho, S., Federighi, M. et al. (2005). Decrease of enteric micro-organisms from rural sewage sludge during their composting in straw mixture. J Appl MicrobiolJ Appl Microbiol. 99, pp. 528-39.

Qamar, F.Naz, Yousafzai, M.Tahir, Khalid, M., Kazi, A.Momin, Lohana, H., Karim, S. et al. (2018). Outbreak investigation of ceftriaxone-resistant Salmonella enterica serotype Typhi and its risk factors among the general population in Hyderabad, Pakistan: a matched case-control study. The Lancet Infectious DiseasesThe Lancet Infectious Diseases. 18, pp. 1368-1376.

Rakowski, K.T. (2012). Thermal inactivation of Escherichia coli 0157:H7 and Salmonella on catfish and tilapia. Food MicrobiologyFood Microbiology. 30, pp. 427-431.

Rani, N., Vajpayee, P., Bhatti, S., Singh, S., Shanker, R. and Gupta, K.Chand (2014). Quantification of Salmonella Typhi in water and sediments by molecular-beacon based qPCR. Ecotoxicology and environmental safetyEcotoxicology and environmental safety. 108, pp. 58-64.

Research, N.Southeast (2017). Causes and outcomes of sepsis in southeast Asia: a multinational multicentre cross-sectional study. Lancet Glob HealthLancet Glob Health. 2017/01/21 ed.5, pp. e157-e167.

Rhodes, M.W. and Kator, H. (1988). Survival of Escherichia coli and Salmonella spp. in estuarine environments. Appl Environ MicrobiolAppl Environ Microbiol. 1988/12/01 ed.54, pp. 2902-7.

Saha, S., Saha, S., Das, R.C., Faruque, A.S.G., Salam, M.A., Islam, M. et al. (2018). Enteric Fever and Related Contextual Factors in Bangladesh. Am J Trop Med HygAm J Trop Med Hyg. 2018/07/27 ed.

Sahlstrom, L., Aspan, A., Bagge, E., Danielsson-Tham, M.L. and Albihn, A. (2004). Bacterial pathogen incidences in sludge from Swedish sewage treatment plants. Water ResearchWater research. 38, pp. 1989-1994. 
Sandvang, D., Jensen, L.B., Baggesen, D.L. and Baloda, S.B. (2000). Persistence of a Salmonella enterica serotype Typhimurium clone in Danish pig production units and farmhouse environment studied by pulsed field gel electrophoresis (PFGE). Fems Microbiology LettersFEMS microbiology letters. 187, pp. 21-25.

Santiago, P., Jimenez-Belenguer, A., Garcia-Hernandez, J., Estelles, R.M., M. Perez, H., Lopez, M.A.Castill et al. (2018). High prevalence of Salmonella spp. in wastewater reused for irrigation assessed by molecular methods. Int J Hyg Environ HealthInt J Hyg Environ Health. 2017/11/07 ed.221, pp. 95-101.

Scaglia, B., D'Imporzano, G., Garuti, G., Negri, M. and Adani, F. (2014). Sanitation ability of anaerobic digestion performed at different temperature on sewage sludge. Science of the Total EnvironmentScience of the total environmentSci Total Environ. 466, pp. 888-897.

Schönning, C. and Stenström, T.Axel (2004). Guidelines on the safe use of urine and faeces in ecological sanitation systems. EcoSanRes publications series, 2004:1. (,. and Programme, E.S.R., ed.). Stockholm Environment Institute. Stockholm. pp. 38.

Schierstaedt, J., Fornefeld, E., Jechalke, S., Schikora, A., Grosch, R. and Smalla, K. (2016). Persistence of Salmonella in agricultural soil is strongly influenced by its bacterial community. IOBC/WPRS BulletinIOBC/WPRS Bulletin. 117, pp. 18-18.

Semenov, A.V., van Overbeek, L. and van Bruggen, A.H.C. (2009). Percolation and survival of E. coli O157:H7 and Salmonella enterica serovar Typhimurium in soil amended with contaminated dairy manure or slurry. Appl. Environ. Microbiol.Appl. Environ. Microbiol. pp. AEM.01791-08.

Shih, J.C.H. (1987). Ecological Benefits of Anaerobic-Digestion. Poultry SciencePoultry science. 66, pp. $946-950$.

Sidhu, J., Gibbs, R.A., Ho, G.E. and Unkovich, I. (2001). The role of indigenous microorganisms in suppression of Salmonella regrowth in composted biosolids. Water ResearchWater researchWater Res. 35, pp. 913-920.

Silva, N.F.D., Magalhães, J.M.C.S., Freire, C. and Delerue-Matos, C. (2018). Electrochemical biosensors for Salmonella: State of the art and challenges in food safety assessment. Biosensors and BioelectronicsBiosensors and Bioelectronics. 99, pp. 667-682.

Simanjuntak, C.H., Paleologo, F.P., Punjabi, N.H., Darmowigoto, R.,.,., Totosudirjo, H. et al. (1991). Oral immunisation against typhoid fever in Indonesia with Ty21a vaccine. LancetLancet. 1991/10/26 ed.338, pp. 1055-9.

Singh, R., Kim, J. and Jiang, X. (2012). Heat inactivation of Salmonella spp. in fresh poultry compost by simulating early phase of composting process. Journal of Applied MicrobiologyJournal of applied microbiologyJ Appl Microbiol. 112, pp. 927-935.

SIS-CEN (2006). Characterization of sludges - Good practice for landfilling of sludges and sludge treatment residues. Swedish Institute for Standards. Stockholm, Sweden.

Smith, S.R., Lang, N.L., Cheung, K.H.M. and Spanoudaki, K. (2005). Factors controlling pathogen destruction during anaerobic digestion of biowastes. Waste ManagementWaste ManagementWaste Management. 25, pp. 417-425.

Smith, S.E., Maurer, J.L., Orta-Ramirez, A., Ryser, E.T. and Smith, D.M. (2001). Thermal inactivation of Salmonella spp., Salmonella typhimurium DT104, and Escherichia coli 0157 : H7 in ground beef. Journal of Food ScienceJ Food Sci. 66, pp. 1164-1168.

Soldierer, W. and Strauch, D. (1991). Kinetics of Death of Salmonellae during Thermal Liquid Manure Disinfection. Journal of Veterinary Medicine Series B-Zentralblatt Fur Veterinarmedizin Reihe B-Infectious Diseases and Veterinary Public HealthJournal of Veterinary Medicine Series B-Zentralblatt Fur Veterinarmedizin Reihe B-Infectious Diseases and Veterinary Public H. 38, pp. 561-574.

Spector, M.P. and Kenyon, W.J. (2012). Resistance and survival strategies of Salmonella enterica to environmental stresses. Food Research InternationalFood Research International. 45, pp. 455-481. 
Spinks, A.T., Dunstan, R.H., Harrison, T., Coombes, P. and Kuczera, G. (2006). Thermal inactivation of water-borne pathogenic and indicator bacteria at sub-boiling temperatures. Water ResearchWater researchWater Res. 40, pp. 1326-1332.

Stephens, P.J., Joynson, J.A., Davies, K.W., Holbrook, R., LappinScott, H.M. and Humphrey, T.J. (1997). The use of an automated growth analyser to measure recovery times of single heat-injured Salmonella cells. Journal of Applied MicrobiologyJournal of applied microbiologyJ Appl Microbiol. 83, pp. 445-455.

Sur, D., Ochiai, R.L., Bhattacharya, S.K., Ganguly, N.K., Ali, M., Manna, B. et al. (2009). A cluster-randomized effectiveness trial of Vi typhoid vaccine in India. N Engl J MedN Engl J Med. 2009/07/25 ed.361, pp. 335-44.

Tauxe, R.V. (1991). Salmonella: A Postmodern Pathogen. Journal of Food ProtectiJournal of Food Protecti. 54, pp. 563-568.

Techasaensiri, C., Radhakrishnan, A., Als, D. and Thisyakorn, U. (2018). Typhoidal Salmonella Trends in Thailand. Am J Trop Med HygAm J Trop Med Hyg. 2018/07/27 ed.

Tennant, S.M., MacLennan, C.A., Simon, R., Martin, L.B. and Khan, M.I. (2016). Nontyphoidal salmonella disease: Current status of vaccine research and development. VaccineVaccine. 2016/04/02 ed.34, pp. 2907-2910.

Termorshuizen, A.J., Volker, D., Blok, W.J., E. Brummeler, ten., Hartog, B.J., Janse, J.D. et al. (2003). Survival of human and plant pathogens during anaerobic mesophilic digestion of vegetable, fruit, and garden waste. European Journal of Soil BiologyEuropean Journal of Soil BiologyEuropean Journal of Soil Biology. 39, pp. 165-171.

Thanh, B.Xuan, Wolff, A., Madsen, M. and Duong, B.Dang (2012). Interaction between food-borne pathogens (Campylobacter jejuni, Salmonella Typhimurium and Listeria monocytogenes) and a common soil flagellate (Cercomonas sp.). Journal of Food ResearchJournal of Food Research. 1, pp. 76-81.

Thomason, B.M., Biddle, J.W. and Cherry, W.B. (1975). DETECTION OF SALMONELLAE IN ENVIRONMENT. Applied MicrobiologyApplied Microbiology. 30, pp. 764-767.

Thomason, B.M., Hebert, G.A. and Cherry, W.B. (1975). EVALUATION OF A SEMIAUTOMATED SYSTEM FOR DIRECT FLUORESCENT-ANTIBODY DETECTION OF SALMONELLAE. Applied MicrobiologyApplied Microbiology. 30, pp. 557-564.

Till, D., McBride, G., Ball, A., Taylor, K. and Pyle, E. (2008). Large-scale freshwater microbiological study: rationale, results and risks. J Water HealthJ Water Health. 6, pp. 443-60.

Trung, N.V., Carrique-Mas, J.J., Nghia, N.H., Tu, L.T., Mai, H.H., Tuyen, H.T. et al. (2017). Non-Typhoidal Salmonella Colonization in Chickens and Humans in the Mekong Delta of Vietnam. Zoonoses Public HealthZoonoses Public Health. 2016/05/07 ed.64, pp. 94-99.

Tsai, C.T., Lai, J.S. and Lin, S.T. (1998). Quantification of pathogenic micro-organisms in the sludge from treated hospital wastewater. J Appl MicrobiolJ Appl MicrobiolJournal of applied microbiology. 1998/08/29 ed.85, pp. 171-6.

Twiddy, N., Hopper, D.W., Wray, C. and McLaren, I. (1988). PERSISTENCE OF S TYPHIMURIUM IN CALF REARING PREMISES. Veterinary RecordVeterinary Record. 122, pp. 399-399.

Uche, I.V., MacLennan, C.A. and Saul, A. (2017). A Systematic Review of the Incidence, Risk Factors and Case Fatality Rates of Invasive Nontyphoidal Salmonella (iNTS) Disease in Africa (1966 to 2014). PLoS Negl Trop DisPLoS Negl Trop Dis. 2017/01/06 ed.11, pp. e0005118.

USEPA (2012). Method 1200: Analytical Protocol for Non-Typhoidal Salmonella in Drinking Water and Surface Water (EPA. EPA 817-R-12-004). U.S. Environmental Protection Agency. Washington, DC, USA.

USEPA (2010). Standard Analytical Protocol for Salmonella Typhi in Drinking Water (EPA/600/R-10/133). U.S. Environmental Protection Agency. Washington, DC.

USEPA (2006). Method 1682: Salmonella in Sewage Sludge (biosolids) by Modified Semisolid Rappaport-Vassiliadis (MSRV) Medium (EPA-821-R06-14). U.S. Environmental Protection Agency. Washington DC, U.S.A. 
Veeramuthu, G.J., Price, J.F., Davis, C.E., Booren, A.M. and Smith, D.M. (1998). Thermal inactivation of Escherichia coli 0157 : H7, Salmonella senftenberg and enzymes with potential as time-temperature indicators in ground turkey thigh meat. Journal of Food ProtectionJournal of food protection. 61, pp. 171-175.

Velliou, E.G., Noriega, E., Van Derlinden, E., Mertens, L., Boons, K., Geeraerd, A.H. et al. (2013). The effect of colony formation on the heat inactivation dynamics of Escherichia coli K12 and Salmonella typhimurium. Food Research InternationalFood Research International. 54, pp. 1746-1752.

Verani, J.R., Toroitich, S., Auko, J., Kiplang'at, S., Cosmas, L., Audi, A. et al. (2015). Burden of Invasive Nontyphoidal Salmonella Disease in a Rural and Urban Site in Kenya, 2009-2014. Clin Infect DisClin Infect Dis. 2015/10/10 ed.61 Suppl 4, pp. S302-9.

Vinneras, B. (2013). Sanitation and Hygiene in Manure Management. Animal Manure Recycling: Treatment and ManagementAnimal Manure Recycling: Treatment and Management. pp. 91-104.

Vinneras, B., Agostini, F. and Jonsson, H. (2010). Sanitation by Composting. Microbes at Work: From Wastes to ResourcesMicrobes at Work: From Wastes to Resources. pp. 171-191.

Vinneras, B., Holmqvist, A., Bagge, E., Albihn, A. and Jonsson, H. (2003). The potential for disinfection of separated faecal matter by urea and by peracetic acid for hygienic nutrient recycling. Bioresource TechnologyBioresource Technology. 89, pp. 155-161.

Vinneras, B., Nordin, A., Niwagaba, C. and Nyberg, K. (2008). Inactivation of bacteria and viruses in human urine depending on temperature and dilution rate. Water ResearchWater researchWater Res. 42, pp. 4067-4074.

Voysey, M. and Pollard, A.J. (2018). Seroefficacy of Vi Polysaccharide-Tetanus Toxoid Typhoid Conjugate Vaccine (Typbar TCV). Clin Infect DisClin Infect Dis. 2018/01/20 ed.67, pp. 18-24.

Wattiau, P., Boland, C. and Bertrand, S. (2011). Methodologies for Salmonella enterica subsp. enterica subtyping: gold standards and alternatives. Appl Environ MicrobiolAppl Environ Microbiol. 2011/08/23 ed.77, pp. 7877-85.

WHO (2018). Guidelines on sanitation and health. World Health Organization. Geneva.

Winfield, M.D. and Groisman, E.A. (2003). Role of nonhost environments in the lifestyles of Salmonella and Escherichia coli. Applied and Environmental Microbiology. 69, pp. 3687-94.

Wong, K., Onan, B.M. and Xagoraraki, I. (2010). Quantification of Enteric Viruses, Pathogen Indicators, and Salmonella Bacteria in Class B Anaerobically Digested Biosolids by Culture and Molecular Methods. Applied and Environmental MicrobiologyApplied and Environmental Microbiology. 76, pp. 6441-6448.

Yen-Phi, V.T., Clemens, J., Rechenburg, A., Vinneras, B., Lenssen, C. and Kistemann, T. (2009). Hygienic effects and gas production of plastic bio-digesters under tropical conditions. Journal of Water and HealthJournal of Water and HealthJ Water Health. 7, pp. 590-596.

Yen-Phi, V.Thi, Rechenburg, A., Vinnerås, B., Clemens, J. and Kistemann, T. (2010). Pathogens in septage in Vietnam. Science of The Total EnvironmentScience of the total environment. 408, pp. 2050-2053.

Zaleski, K.J., Josephson, K.L., Gerba, C.P. and Pepper, I.L. (2005). Potential regrowth and recolonization of salmonellae and indicators in biosolids and biosolid-amended soil. Appl Environ MicrobiolAppl Environ Microbiol. 71, pp. 3701-8. 